\title{
ANÁLISE DO PERFIL EPIDEMIOLÓGICO DA TRANSMISSÃO VERTICAL DO HIV NO ESTADO DO ESPÍRITO SANTO, NO PERÍODO DE 1999-2002
}

\author{
VERA LÚCIA CARPENTER
}

Dissertação apresentada ao Programa de PósGraduação em Saúde Pública para obtenção do Título de Mestre em Saúde Pública.

Área de concentração: Serviços de Saúde Púbilica.

Orientador: Prof. Dr. Roberto Augusto Castellanos Fernandez.

SÃo PAULO

2005

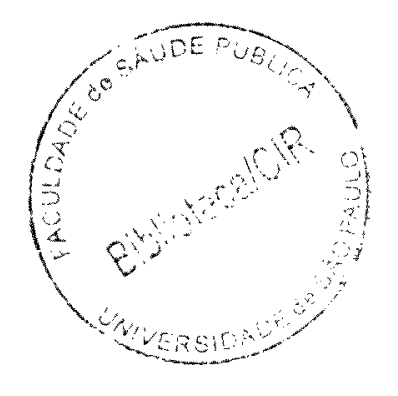


Autorizo, exclusivamente para fins acadêmicos e científicos, a reprodução total ou parcial desta dissertação, por processos fotocopiadores. Ao usá-lo, cite a fonte.

Assinatura:

Data:

$$
45849 / 2005 \text { doc }
$$


"É o outro que me dá referência de que nem sou o anão dos meus pesadelos, nem o gigante dos meus sonhos".

Autor desconhecido. 
Às minhas filhas amadas, Beatriz e Martha Lúcia, tesouros preciosos que têm me ensinado tanto $e$ são a alegria do meu viver.

À minha mãe, responsável por tudo, ontem, hoje e sempre, e ao meu "paidrasto" Jair Costa dos Santos, que sempre me apoiou. 


\section{AGRADECIMENTOS}

\section{Agradeço ao Deus vivo que, em nome de Jesus, tornou o aparentemente impossível, possível!}

\section{Obrigado, Senhor!}

Ao Prof. Dr. Roberto Augusto Castellanos Fernandez, pela dedicação na orientação deste trabalho e pela forma amiga e incentivadora de todas as horas;

À Prof. ${ }^{a}$ Dr.a Néia Schor e à Prof.a Kátia Pirotta, pelas contribuições e sugestões;

Ao Prof. Dr. João Sossai, pessoa fundamental neste processo de aprendizagem, pela forma amiga e carinhosa com que me apoiou sempre.

Aos demais Mestres da casa, pelos conhecimentos transmitidos, pela colaboração e apoio que foram de fundamental importância para a realização deste;

À Diretoria da Pós-Graduação da Universidade de São Paulo e da FAESA, pelo apoio institucional e pelas facilidades oferecidas;

À Dra Sandra Fagundes, Coordenadora do Programa Estadual do DST/Aids SESA - ES e à Rozângela Locateli Armani, Assistente Social da Coordenação Estadual DST e Aids da SESA-ES, pela disponibilidade com que favoreceram o desenvolvimento deste estudo; 
Às minhas irmãs Andréia Carpenter e Raquel Carpenter, e ao Gilson da Paixão, que me apoiaram em todos os momentos;

Às minhas queridas amigas, Janete Mathielo Gomes e Izaura Serpa Kaiser, e aos meus queridos amigos, Caio Mathielo Gomes e João Carlos Marins, pelo incentivo, paciência e dedicação na apresentação e formatação deste trabalho;

Aos meus sobrinhos amados e queridos, Samuel Carpenter da Paixão e Júlia Carpenter da Paixão, Marcela Carpenter da Paixão, pela alegria, inocência e confiança, que estimulam o meu viver;

Ao meu pai, Gildo Luiz da Silva, que me ensinou que perdoar é uma dádiva de amor;

Para as pessoas maravilhosas que, durante a minha vida, compartilharam meu carinho, mesmo que por breve instante, e que me ajudaram a aprender mais e mais, no decorrer de minha existência. 


\section{RESUMO}

Carpenter VL. Análise do Perfil Epidemiológico da Transmissão Vertical do HIV no Espírito Santo, no período de 1999-2002. São Paulo; 2005. [Dissertação de Mestrado - Faculdade de Saúde Pública da USP].

Objetivo. Realizou-se estudo com o objetivo de analisar o perfil epidemiológico da transmissão vertical do HIV no Estado do Espírito Santo, no período de 1999 - 2002. Método. Este é um estudo retrospectivo de análise de dados secundários, coletados das Fichas de Notificação/Investigação Gestantes HIV+ e Crianças Expostas - SISGHIV, cedidas pela Secretaria Estadual da Saúde do Estado do Espírito Santo SESA, disponíveis no Banco de Dados do SINAN/SESA/Programa Estadual de DST/Aids. A coleta de dados foi realizada pelo pesquisador, mediante consulta a 188 fichas registradas no SINAN de casos notificados de gestantes HIV+. Buscou-se verificar a tendência na taxa de transmissão vertical do HIV no Estado, identificar o perfil da gestante infectada e identificar o número de gestantes e recém-nascidos que fizeram uso da terapêutica para prevenção da Aids pediátrica, no período do estudo. Resultados. A análise do estudo mostrou que: 137 (72,9\%) gestantes tiveram confirmação do diagnóstico laboratorial do HIV, no início do pré-natal; a idade gestacional, no início da profilaxia com AZT, ocorreu em maior número na $16^{\mathrm{a}}$ semana (10,6\%); 105 $(55,9 \%)$ gestantes fizeram pré-natal; o tempo de uso do AZT oral pelas gestantes entre as $13^{\mathrm{a}}$ e $26^{\mathrm{a}}$ semanas foi de $(20,7 \%) ; 166(88,3 \%)$ recémnascidos nasceram vivos; 141 (75\%) recém-nascidos receberam AZT nas primeiras 24 horas (número de ignorados 20,7\%); 7 (3,7\%) recém-nascidos tiveram diagnóstico positivo para HIV pela transmissão materno-infantil e 64 (34\%) recém-nascidos tiveram resultado negativo. Conclusões. Concluiu-se que existe uma infra-estrutura básica para a realização de intervenções para a prevenção da transmissão vertical do HIV. Os dados aqui apresentados sugerem que 0 baixo número de gestantes tratadas está associado à dificuldade de identificar a gestante infectada pelo HIV durante o pré-natal. Neste sentido, pelo menos dois fatores podem estar relacionados à dificuldade: a qualidade da assistência prestada à mulher durante a gestação e o parto e 0 acesso aos testes anti-HIV.

Descritores: Aids, HIV, Transmissão Vertical, antiretrovirais, gestantes HIV. 


\section{SUMMARY}

Carpenter VL. Analysis of the Epidemiologist Profile on the HIV Vertical Transmission in the State of Espírito Santo, during the period of 1999-2002. São Paulo; 2004. [Mastership Thesis - Faculdade de Saúde Pública da USP].

Purpose. The study were carried out with the purpose of analyze the epidemiologist profile on the HIV vertical transmission in the state of Espírito Santo during the period of 1999-2002. Method. This is a retrospective study made with secondary data analyses that were collected through notification forms and investigation forms of the HIV+ pregnants and exposed children. All data were given by the State Secretary for the Health of the State of Espirito Santo, available in the data bank of the SINAN/SESA/State Program of DST/Aids. The data were collected by the researcher through the 188 registered forms of pregnants HIV cases in the SINAN, the intention of this research is try to verify the tendencies of the HIV vertical transmission rate in the state of Espirito Santo, identify the infected pregnant profile, identify the amount of pregnants and newborn babies that used this therapy to infants aids prevention in the period of the study. Results. The research analysis shown that: $137(72,9 \%)$ of pregnants had diagnostical confirmation of HIV at the beginning of prenatal; the pregnancy age in the beginning of prophylaxis with AZT, appears mostly in the $16^{\mathrm{a}}$ week $(10,6 \%) ; 105(55,9 \%)$ of pregnants completed the prenatal; the period that the pregnants between the $13^{\mathrm{a}}$ and $26^{\mathrm{a}}$ week took oral AZT in the last 24 hours (number of ignored $20,7 \%) ; 166(88,3 \%)$ of newborn were born alive; $141(75 \%)$ of newborn took AZT in the first 24 hours; $7(3,7 \%)$ newborn had positive diagnostical for HIV by the maternal-infantile transmition and 64 (34\%) newborn had negative results. Conclusions. We concluded that there is a basic infrastructure to make interventions to avoid the HIV vertical transmission. The data hereby suggests that the low number of pregnant treated is related to the difficulty in find which pregnant is infected during the prenatal. Therefore, at least two reasons can be related to the difficulty: the bad quality care given to woman during pregnancy and birth and the access to the HIV tests.

Describers: Aids, HIV, Vertical Transmission, anti-retorviral, HIV pergnants. 


\section{ÍNDICE}

1. INTRODUÇÃO

1.1 Aids: contexto mundial e realidade brasileira ___ 3

1.2. Medicalização da Aids _ 12

1.3.Transmissão Vertical

1.4. Transmissão Vertical nas Regiões do Brasil e no Estado do Espírito Santo

1.5.0 Perfil da Paciente Infectada___ 26

1.6.0 Binômio Gravidez/Aids ___ 27

1.7. Controle da Aids no Estado do Espírito Santo___ 31

2. OBJETIVOS 36

2.1 Objetivo Geral __ 36

2.2 Objetivos Específicos _ 36

3. MATERIAL E MÉTODO _ 37

3.1 Tipo de Estudo__ 37

3.2 Local do Estudo 37

3.3 Local de Coleta de Dados

3.4 Período do Estudo _ 42

3.5 Variáveis de Estudo _ 42

3.6 Aspectos Éticos

3.7 População de Estudo __ 43

4. RESULTADOS

5. DISCUSSÃO _ 62

6. CONSIDERAÇÕES FINAIS _ 75

7. REFERÊNCIAS 80

ANEXO 


\section{LISTA DE FIGURAS}

Figura 1 HIV atacando um glóbulo branco 4

Figura 2 VÍRUS HIV (pequenos pontos pretos), atacando células do 4 sangue

Figura 3 Infecção por Aids no mundo atual 8

Figura 4 Proporção de casos de Aids em menores de 13 anos, segundo 18 categoria de transmissão. Brasil, 1983 - 1999

Figura 5 Casos de Aids em menores de 13 anos, segundo categoria de 19 transmissão e ano do diagnóstico. Brasil, 1983 - 1999.

Figura 6 Taxa de incidência de Aids (por 100.000 hab.), segundo ano de diagnóstico e região de residência. Brasil, 1991-2002

Figura 7 Incidência da Aids em mulheres, crianças, e por transmissão perinatal. Brasil, 1985 - 1998/99

Figura 8 Distribuição de idade no momento da notificação dos casos de Aids em menores de 13 anos, infectados por via vertical, segundo região de residência. Brasil, 1983 - 1999 (até agosto)

Figura 9 Proporção de casos de Aids em menores de 13 anos, infectados por via vertical, segundo categoria de exposição da mãe. Brasil, 1983 - 1999 (até agosto)

Figura 10 Proporção de casos de Aids em menores de 13 anos infectados por via vertical, segundo categoria de exposição da mãe por regiões. Brasil, 1983 - 1999 (até agosto)

Figura 11 Distribuição proporcional dos casos de Aids por transmissão vertical, segundo características da parceria da mãe na categoria de exposição heterossexual. Brasil, 1993 - 1999

Figura 12 Distribuição proporcional dos casos de Aids por transmissão vertical, segundo características da parceria da mãe na categoria de exposição heterossexual, por regiões. Brasil, 1993 $-1999$

Figura 13 Distribuição proporcional dos casos de Aids por transmissão vertical, segundo características da parceria da mãe na categoria de exposição heterossexual, nas capitais com maiores taxas de incidência. Brasil, $1993-1999$ 


\section{LISTA DE TABELAS}

Tabela 1 Distribuição dos casos de Aids entre indivíduos de 15 a 19 anos 11 de idade, segundo ano de diagnóstico e razão por sexo. Brasil, 1990-1999

Tabela 2 Distribuição das gestantes HIV+, registradas na SESA por ano de 45 diagnóstico, no período de 1999-2002. ES, 2004

Tabela 3 Distribuição das gestantes HIV+, registradas na SESA, segundo 46 município de notificação, no período de 1999-2002. ES, 2004.

Tabela 4 Distribuição das gestantes HIV+, registradas na SESA, segundo município de residência, no período de 1999-2002. ES, 2004

Tabela 5 Distribuição das gestantes HIV+, registradas na SESA, segundo 49 município de residência e notificação, no período de 1999-2002. ES, 2004

Tabela 6 Distribuição das gestantes HIV+, registradas na SESA, segundo 50 escolaridade, no período de 1999-2002. ES, 2004

Tabela 7 Distribuição das gestantes HIV+, registradas na SESA, segundo 50 faixa etária, no período de 1999-2002. ES, 2004

Tabela 8 Distribuição das gestantes HIV+, registradas na SESA, segundo 51 faixa e escolaridade, no período de 1999-2002. ES, 2004

Tabela 9 Distribuição das gestantes HIV+, registradas na SESA, segundo 52 categoria de exposição, no período de 1999-2002. ES, 2004

Tabela 10 Distribuição das gestantes HIV+, registradas na SESA, segundo 52 realização de pré-natal, no período de 1999-2002. ES, 2004

Tabela 11 Distribuição das gestantes HIV+, registradas na SESA, segundo 53 época do diagnóstico laboratorial do HIV, no período de 19992002. ES, 2004

Tabela 12 Distribuição das gestantes HIV+, registradas na SESA, segundo idade gestacional no inicio da profilaxia, no período de 19992002. ES, 2004

Tabela 13 Distribuição das gestantes HIV+, registradas na SESA, segundo 55 uso de antiretrovirais, no período de 1999-2002. ES, 2004

Tabela 14 Distribuição das gestantes HIV+, registradas na SESA, segundo 55 tempo de uso de AZT oral, no periodo de 1999-2002. ES, 2004 


\section{LISTA DE TABELAS}

Tabela 15 Distribuição das gestantes HIV+, registradas na SESA, segundo 56 casos confirmados de Aids, no período de 1999-2002. ES, 2004

Tabela 16 Distribuição das gestantes HIV+, registradas na SESA, segundo 56 confirmação de Aids e uso de anti-retroviral, no período de 19992002. ES, 2004

Tabela 17 Distribuição das gestantes HIV+, registradas na SESA, segundo 57 gestantes que fizeram pré-natal, no período de 1999-2002. ES, 2004

Tabela 18 Distribuição das gestantes HIV+, registradas na SESA, segundo 57 tipo de desfecho da gestação, no período de 1999-2002. ES, 2004

Tabela 19 Distribuição das gestantes HIV+, registradas na SESA, segundo uso de AZT durante parto, no período de 1999-2002. ES, 2004

Tabela 20 Distribuição das gestantes HIV+, registradas na SESA, segundo desfecho da gestação e uso de AZT durante o parto, no período de 1999-2002. ES, 2004

Tabela 21 Distribuição das gestantes HIV+, registradas na SESA, segundo aleitamento materno, no período de 1999-2002. ES, 2004

Tabela 22 Distribuição das gestantes HIV+, registradas na SESA, segundo 60 produto do desfecho da gestação, no período de 1999-2002. ES, 2004

Tabela 23 Distribuição das gestantes HIV+, registradas na SESA, segundo 60 tempo transcorrido até o uso do AZT pelo recém-nascido, no período de 1999-2002. ES, 2004

Tabela 24 Distribuição das gestantes HIV+, registradas na SESA, segundo 61 sorologia da criança, após 24 meses, no período de 1999-2002. ES, 2004

\section{LISTA DE QUADRO}

Quadro 1 Estimativa populacional do Estado do Espirito Santo por macro- 40/41 região e municípios em 2001. Instituto Brasileiro de Estatística, 2001 


\section{INTRODUÇÃO}

A Síndrome da Imunodeficiência Adquirida - Aids - é caracterizada como uma doença infecciosa transmissível, que tem se expandido, de forma expressiva, desde os anos 80, sendo a sua cura, ainda, desconhecida. Esta doença é um grave problema para a Saúde Pública, com repercussões psicológicas, sociais, culturais e políticas.

Toda doença é uma experiência à condição humana e só deixa de ser um evento dotado de neutralidade, à medida que Ihe são atribuidos significados, significados estes que variam, de acordo com os determinantes sociais e culturais de cada época.

A imagem inicial da Aids, como uma doença nova, contagiosa, incurável, mortal, diretamente ligada à sexualidade e vinculada a grupos minoritários, por si só, socialmente marginalizados, e associados à idéia de desvio (homossexuais, usuários de drogas, prostitutas), acabou por conferir-lhe o excepcional poder de provocar articulações de três questões muito mal resolvidas em nossa sociedade moderna: a morte, o contágio e a sexualidade. Muitos dos estigmas e fantasmas ligados a cada um desses temas já foram vividos socialmente em face de outras enfermidades (a lepra, a sífilis, a tuberculose, o câncer). Em relação à Aids, porém, todos esses estigmas e representações associaram-se e potencializaram a construção de um campo imaginário, individual e social, terrorífero e persecutório por excelência, que se sobrepõe, em muito, à patologia em si.

Entre as inúmeras questões levantadas pela Aids, ganha destaque, em todo mundo, a velocidade do crescimento com que a epidemia se manifesta entre as mulheres.

No Brasil, estatísticas oficiais apontam para um importante deslocamento no padrão de expansão da epidemia, a partir da segunda metade dos anos 80: de um padrão no qual predominavam as categorias de homossexuais e bissexuais masculinos e de usuários de drogas injetáveis, para um padrão cada vez mais vinculado à transmissão heterossexual. Começa a se configurar um novo perfil da 
Aids, em que a mulher passa a ocupar um lugar cada vez mais destacado (MS 2000).

Conforme documentos oficiais do Ministério da Saúde ( MS 2000), sendo as mulheres mais suscetíveis às doenças sexualmente transmissiveis do que os homens, a incidência do risco de transmissão do HIV, nesse grupo, é preocupante e requer atenção especial, principalmente, na gravidez, por implicar, também, o bem estar do feto e a estrutura da família, especialmente, outros filhos. Como decorrência da crescente contaminação de mulheres pelo vírus HIV, atualmente, presencia-se o crescimento significativo do número de casos de Aids entre recémnascidos. De acordo com o Ministério da Saúde (MS 2000), a primeira ocorrência de transmissão perinatal, registrada, no Brasil, foi em 1985. Daí, até 03/06/2000, foram notificados 5.409 casos dessa forma de transmissão.

A mulher infectada pode transmitir o HIV a seu feto, por via transplacentária, durante o primeiro trimestre da gravidez, sendo que $30 \%$ a $60 \%$ dos fetos de mães soro positivas foram infectados durante esse período, havendo, ainda, casos descritos em que a transmissão do HIV ao recém-nascido pode ter ocorrido através do leite materno. A via perinatal, então, depois da sexual e da sangüínea, é a terceira em freqüência, já comprovada, para a infecção pelo HIV (MINISTÉRIO DA SAÚDE 2000).

De fato, o número de mulheres contaminadas pelo HIV vem apresentando um crescimento importante na transmissão heterossexual. A faixa etária que compreende o maior número de casos está entre 20 e 49 anos. Como conseqüência, nota-se um aumento do número de casos SIDA/Aids em crianças, reflexo do acometimento progressivo de mulheres. Atualmente, cerca de $90 \%$ dos casos de crianças infectadas se devem à transmissão vertical (MINISTÉRIO DA SAÚDE 2000).

Diante desse quadro, propusemo-nos, a partir do contexto da inserção da mulher no novo perfil da Aids, a analisar o perfil epidemiológico da transmissão vertical no Estado do Espírito Santo, no período de 1999 - 2002. 


\subsection{Aids: contexto mundial e realidade brasileira}

A Síndrome da Imunodeficiência Adquirida - Aids -, causada pelo Vírus da Imunodeficiência Humana - HIV, foi reconhecida, em 1981, pelo órgão americano Center for Disease Control (CDC), como uma doença fatal, que atinge o sistema imunológico, a ponto de tornar mortais infecções, geralmente, corriqueiras, e para a qual ainda não se descobriu a cura.

De acordo com SMELTZER e BARE (2002), o vírus HIV faz parte do grupo dos retrovírus que, embora mais simples que os vírus comuns, é mais difícil de ser combatido. Sua principal característica é ter o patrimônio genético registrado na forma de RNA (Ácido Ribonucléico) e uma membrana lipídica circundando a cápside. Possui, também, uma enzima denominada transcriptase reversa que tem por função transformar o código genético de RNA para DNA (Ácido dexosoribonucléico), facilitando sua integração dentro do material genético da célula hospedeira. Uma vez inserido, ele condiciona essa célula, aproveitando-se do seu metabolismo para replicar-se a si mesmo, ou seja, produzir mais células RNA

O vírus ataca um tipo de glóbulo branco - célula de defesa - chamado CD4. No processo, o HIV aloja seu gene no DNA da célula CD4 atingida e passa a utilizála para se multiplicar e, com isso, contaminar novas células (SONTAG 1989; CZERESNIA 1997; SOARES 2001; SMELTZER e BARE 2002).

De acordo com esses autores, durante esse processo, as células CD4 acabam morrendo, por razões ainda não totalmente conhecidas. Com a redução do número desses glóbulos brancos, o organismo começa a perder a capacidade de combater doenças até atingir o ponto crítico que caracteriza a Aids (Figura1). 
Figura 1 - HIV atacando um glóbulo branco.

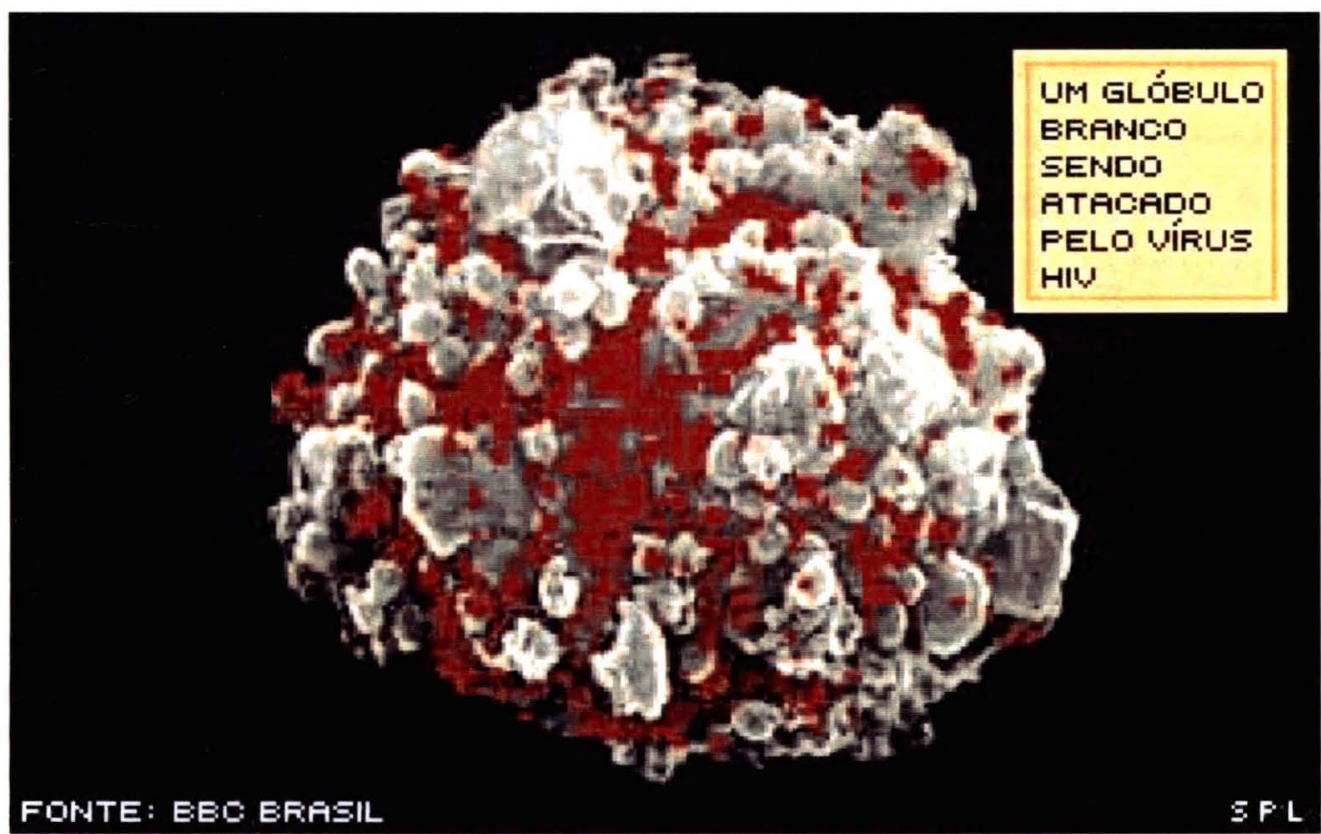

De acordo com esses autores, durante esse processo, as células CD4 acabam morrendo, por razões ainda não totalmente conhecidas. Com a redução do número desses glóbulos brancos, o organismo começa a perder a capacidade de combater doenças até atingir o ponto crítico que caracteriza a Aids (Figura 2).

Figura 2 - VÍRUS HIV (pequenos pontos pretos), atacando células do sangue.

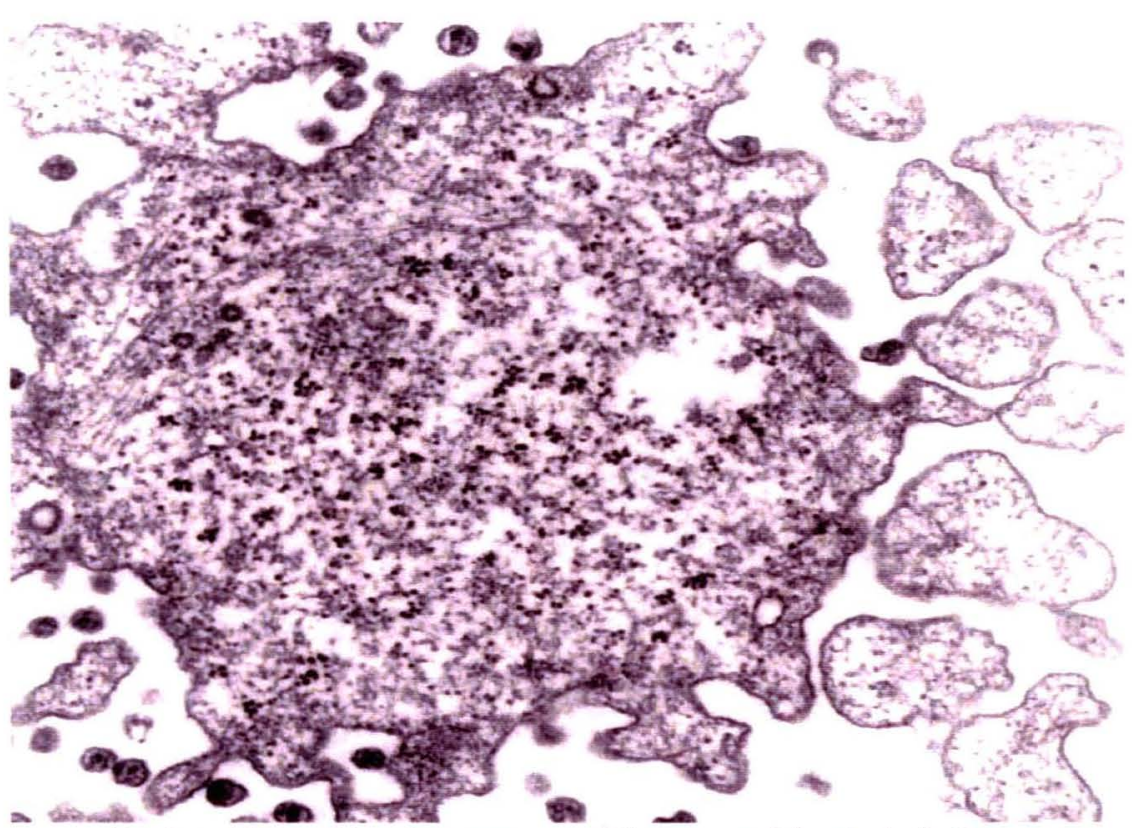

Fonte: Dicionário de termos médicos e saúde, de Luís Rey. 
Embora não se conheça a origem do HIV, sabe-se que existe semelhança com a família de retrovírus, relacionada a primatas não-humanos - macacos verdes africanos -, que vivem na África sub-saariana, chamada de Vírus da Imunodeficiência Símica - SIV. Em rituais religiosos, o homem teria sacrificado o animal, ingerindo seu sangue; assim, o vírus SIV pode ter sofrido mutação e passado a atacar a espécie humana (SONTAG 1989; CZERESNIA 1997; SOARES 2001).

A hipótese de que o vírus tenha sido transferido dos macacos para os humanos data do final do século XIX, ficando isolado em uma pequena população até então; existe, ainda, a possibilidade de que ele tenha atingido os homens por volta de 1930, espalhando-se imediatamente (CZERESNIA 1997; SOARES 2001; SZWARCWALD E CARVALHO 2001).

Cientistas britânicos e americanos, liderados por Bette Korba, do Laboratório Nacional de Los Alamos, no Novo México, descobriram que as atuais cepas do HIV têm um ancestral comum, que viveu há 70 anos. A partir disso, procuraram reconstituir a "árvore genealógica" do HIV, usando a variação entre as cepas atuais, como um relógio, a fim de calcular seu tempo de evolução. Como os genes mudam num ritmo constante, é possivel estimar quando as cepas principais se separaram de sua origem comum. Segundo esses cientistas, essa divisão deve ter ocorrido entre 1915 e 1941, mais provavelmente, em 1931 (SONTAG 1989; BUCHALLA 2000; SOARES 2001).

Ainda, são esses autores a relatarem que, no início da década de 80 , médicos começaram a perceber que doenças, antes consideradas fracas e que não afetariam os serem humanos, começaram a aparecer em algumas pessoas, de forma bastante forte. Com o passar dos anos, pesquisas científicas identificaram o causador desse fenômeno: o vírus HIV, que ataca o sistema de defesa do corpo humano e deixa o espaço livre para essas doenças mais fracas, denominadas "oportunistas".

Nos primeiros anos, a epidemia da Aids e o estudo de sua distribuição na população eram vinculados à incidência, quase exclusiva, entre homossexuais masculinos. Enquanto se procurava uma explicação para o surto dessa síndrome desconhecida, tal dado epidemiológico foi central: procurava-se uma ligação 
intrínseca entre a homossexualidade e a Aids. Esse elo associativo disseminou-se rapidamente por todos os âmbitos relacionados à Aids: na epidemiologia, na clínica, nas pesquisas científicas, na mídia e na opinião pública.

Em 1983, o vírus responsável pela Síndrome de Deficiência Imunológica Adquirida - Aids - foi isolado pelos pesquisadores Robert Gallo, nos EUA, e Luc Montagnier, na França. Em 1986, um comitê internacional recomendou o termo Vírus da Imunodeficiência Humana - HIV - para denominá-lo, reconhecendo-o como capaz de infectar seres humanos (SONTAG 1989; SOARES 2001).

Logo depois da identificação do vírus, pesquisadores começaram a investigar a forma pela qual ele poderia estar sendo transmitido, constatando-se, então, que era através do sangue, ou pela troca de fluídos corporais.

Os primeiros casos reconhecidos o foram em pacientes homossexuais masculinos, procedentes de grandes cidades norte-americanas (Nova York, Los Angeles e São Francisco), devido à grande incidência de casos de Sarcoma de Kaposi e Pneumonia. Por causa disso, no inicio, as pessoas tendiam a acreditar que só quem participasse dos chamados grupos de risco - como homossexuais masculinos, profissionais do sexo, viciados em drogas que compartilham seringas contaminadas, entre outros - poderia contrair a doença. Além desses "grupos de risco", havia, também, o risco de contaminação por transfusão de sangue contaminado, mas esta forma de contaminação teve redução significativa, quando os bancos de sangue foram obrigados a fazer testes para se ter certeza de que não havia sangue contaminado pelo HIV. Ainda assim, certas características epidemiológicas permaneciam, sugerindo uma etiologia infecciosa, transmitida por via sexual, vertical e parental (MONTAGNIER 1995, 1996).

É desse autor, ainda, a análise de que a idéia de grupos de risco caiu por terra no começo da década de 90 , quando se percebeu que, o que existe são "comportamentos de risco", como fazer sexo sem proteção ou compartilhar seringas contaminadas, em face da descoberta de casos entre heterossexuais e crianças recém-nascidas.

A ação do vírus HIV gera, ao longo do tempo, a Síndrome de Deficiência Imunológica Adquirida - SIDA -, mais conhecida, no Brasil, por sua sigla em inglês, Aids. Esta síndrome danifica, lentamente, o sistema de defesa do organismo, 
podendo levar o ser humano à morte. Estar com o vírus HIV, no entanto, não significa, necessariamente, estar com Aids. Isto quer dizer que algumas pessoas podem ter o vírus, mas não desenvolverem a doença. Hoje, com a criação de medicamentos e o desenvolvimento do coquetel, médicos conseguem reduzir a infecção por HIV, e, por conseqüência, evitar que a Aids se desenvolva (SONTAG 1989; SOARES 2001).

O surgimento do coquetel, que consegue bloquear o desenvolvimento do HIV no organismo, foi um importante passo para a luta contra a doença, já que ele ajuda os portadores do vírus a viverem melhor. Mas, ressaltam os médicos, o coquetel não representa a cura da Aids e, como o HIV é mutante, pode ser que, no futuro, surjam tipos resistentes ao coquetel. Por isso, a melhor forma de combater a Aids continua sendo a prevenção, conforme assinalam SONTAG (1989) e SOARES (2001).

A Aids é caracterizada, sem dúvida, como uma pandemia, em face de sua magnitude (Figura 3). Para se ter idéia da dimensão do problema, segundo o último relatório do UNAIDS, Programa da Organização das Nações Unidas - ONU para a Aids, divulgado no início de julho de 2002, a doença matou um número recorde de três milhões de pessoas em 2001, das quais, 2,2 milhões somente na África, e o HIV infectou outras cinco milhões de pessoas em todo o mundo. A Aids, que fez milhões de vítimas fatais, desde sua identificação, em 1981, já deixou 14 milhões de órfãos. Há cerca de 20 anos, o número de mulheres infectadas era de uma para 50 homens, já, em 2002, era de uma para cada dois homens infectados. Atualmente, três milhões, dentre os 40 milhões infectados, são crianças e adolescentes com menos de 15 anos (WHO 2002). 
Figura 3 - Infecção por Aids no mundo atual.

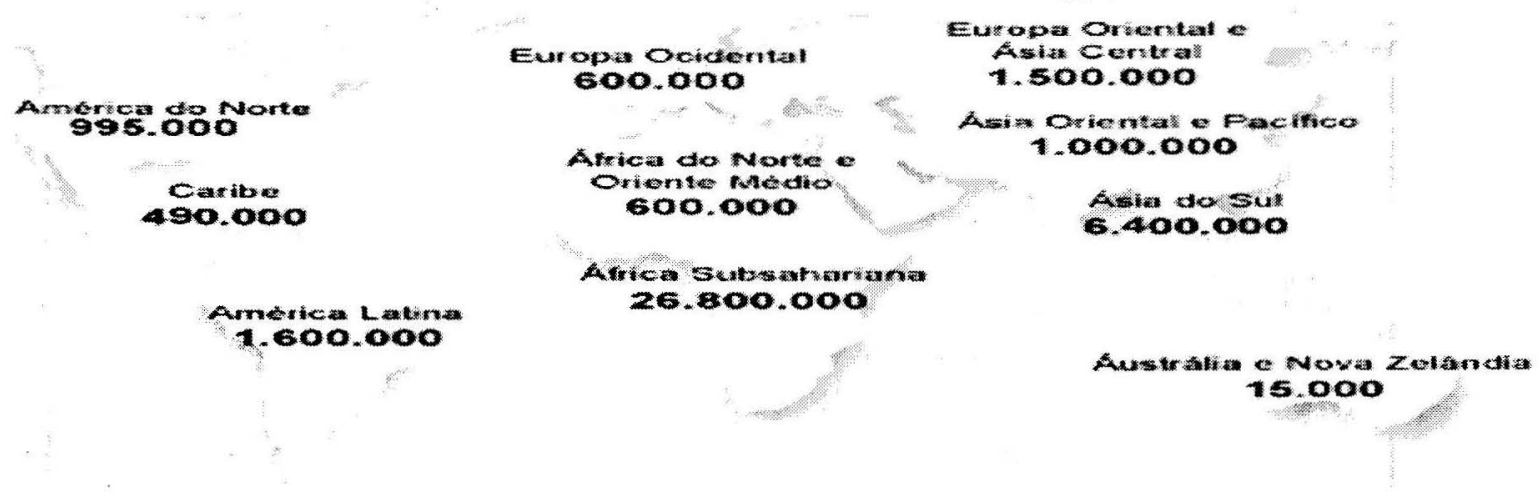

Fonte: Agência de Notícias da Aids, 2002.

Novas vacinas estão sendo testadas em diversos países e campanhas de prevenção têm diminuído o ritmo de crescimento do número de casos. É alarmante, no entanto, a situação da África, que concentra $76 \%$ dos portadores de HIV do mundo e 70\% dos novos casos de contaminação pelo vírus, ao longo de 2001 (WHO 2002).

No continente africano, a situação já se tornou o maior desafio social para os seus países. Naqueles, onde a situação é mais crítica, cerca de 1.000 adultos e crianças morrem de Aids, por dia. O problema já chega ao extremo, pois tem sido uma ameaça para a força de trabalho, assim como vem reduzindo, de forma significativa, a população jovem.

Na região sub-saariana, em 2001, 9\% dos adultos, na faixa etária de 15 a 49 anos, estavam infectados, superando os $8,6 \%$ registrados em 1999. A epidemia está sendo disseminada, principalmente, através de relações heterossexuais, sem o uso de preservativo.

Entretanto, a África não é o único continente ameaçado pelo HIV. A doença também está se espalhando rapidamente na Europa Oriental e no leste da Ásia, onde a população infectada praticamente duplicou de 1990 a 2000 (WHO 2000, 2002). 
A doença, pelo vírus do HIV, constitui importante problema para a Saúde Pública, visto que a Aids se apresenta como uma das principais causas de morte prematura, especialmente, no grupo etário entre 15 e 49 anos. Essa mortalidade está, em grande parte, relacionada a infecções oportunistas graves e neoplasias, decorrentes do comprometimento do sistema imunológico (MONTAGNIER 1996).

Segundo previsões da Organização das Nações Unidas para a Aids (UNAIDS), acreditava-se que, no ano de $2000,43.728 .703$ homens, mulheres e crianças em todo o mundo estariam vivendo com HIV/Aids, em estágio assintomático, ou já sofrendo as conseqüências clínicas da infecção. Essa previsão foi baseada em modelos de progressão epidemiológica com base nos dados relatados por cada país do mundo. Esse número é provavelmente subestimado devido, em grande parte, à ineficácia ou mesmo ausência de implementação de censo epidemiológico em muitos países do Terceiro Mundo. (WHO/UNAIDS 2002, p. 18).

Estimativas feitas pela UNAIDS, em 1991, relatavam que, até o fim da década, somente na África subsaárica (a parte do globo mais afetada pela Aids), cerca de 9 milhões de pessoas estariam infectadas pelo vírus, e outras 5 milhões teriam morrido. Esses números foram subestimados, já que morreram três vezes mais pessoas do que havia sido previsto (WHO 2000, 2002).

Na última década, a Aids tornou-se uma questão de Segurança Pública em algumas nações do continente africano, influenciadas pelas elevadas taxas de mortalidade infantil, pelas questões relacionadas à expectativa de vida, dentre outros aspectos, minando suas economias e estagnando o crescimento econômico, desencadeando uma crise no desenvolvimento dessas nações.

Mais de 20 anos após a identificação do HIV, ainda não há vacina contra o vírus, nem cura para a doença. Mas a expectativa de vida dos portadores do HIV aumentou significativamente, graças à nova geração de medicamentos usados no combate à Aids (WHO 2000, 2002).

De fato, esforços de cientistas, médicos e políticos de todo o mundo conseguiram conquistar grandes avanços no combate à doença. A vida do soropositivo, hoje, é radicalmente mais saudável que a de pessoas que contraíram a doença há mais de 20 anos. No Brasil, os empenhos do Ministério da Saúde, por 
exemplo, colocaram o país em uma posição de liderança mundial no combate à doença, por meio de ações de Saúde Pública, como a distribuição gratuita do coquetel, através do sistema Único de Saúde - SUS (VENTURA 2001; SMELTZER e BARE 2002).

No Brasil, a situação epidemiológica da Aids tem melhorado consideravelmente, especialmente, nos últimos anos, graças ao alto comprometimento do governo, traduzido em ações do Ministério da Saúde no controle da doença. As taxas de crescimento da epidemia têm sofrido desaceleração no país. De 1987 a 1992, o Brasil registrou uma taxa de 36\% de infectados por ano; de 1990 a 1996, essa taxa caiu para 12\%. Uma correlação entre o nível sócioeconômico e a incidência da Aids pode ser constatada, o que ocorre, a propósito, na grande maioria dos países. Verificou-se que cerca de $76 \%$ de todos os casos registrados, no país, em 1999/2000, o foram em indivíduos analfabetos, ou que haviam cursado apenas o primeiro grau (PARKER 1994; MS 1999, 2002).

A Aids, ainda, é responsável por um grande número de óbitos. Somente em 1999, 18 mil adultos e crianças morreram de Aids, no Brasil, ao lado de mais de 30 mil crianças e adolescentes órfãos, com menos de 15 anos de idade, em função da epidemia. Em termos cumulativos, desde o início da propagação da Aids, no começo dos anos 80, até 1999, mais de 41 mil crianças ficaram órfãs (SANTO e col. 2000; SZWARCWALD E CARVALHO 2001).

Até o final de 1999, cerca de 540 mil brasileiros estavam convivendo com o HIV, seja em caráter assintomático, ou não. Destes, 530 mil eram jovens e adultos, entre 15 e 49 anos, e 10 mil crianças e adolescentes, de até 15 anos de idade. 0 país apresenta uma taxa de prevalência, em adultos, de cerca de 0,57\%. Atualmente, $59 \%$ de todos os 5.507 municipios brasileiros já registraram, ao menos, um caso de Aids (MS 1999, 2002; SANTO e col. 2000; SZWARCWALD e CARVALHO 2001).

De acordo com dados do Ministério da Saúde, a Aids, no Brasil, até dezembro de 2002, já havia atingido o número de 257.780 casos, sendo 185.061 em homens e 72.719 em mulheres (MS 2002).

No final de 1999, levado em consideração o número de 100 mil mulheres portadoras do vírus HIV, a infecção ainda apresentava uma prevalência maior em 
individuos do sexo masculino, atingindo 400 mil homens. A proporção entre homens e mulheres infectados pelo vírus do HIV tem diminuído, ao longo dos anos, tendo sido de 24:1, em 1985; 9:1, em 1987, e 5:1, em 1991, com previsão de que essa proporção chegaria a 2:1 em 2003 (MS 1999a, 2002).

De acordo com o Boletim Epidemiológico de 1999 (MS 1999c), a partir de 1993, observa-se, no grupo etário de 15 a 19 anos, uma proporção maior de mulheres infectadas em relação a anos anteriores, chegando à razão de 1:1 a partir de 1996, conforme pode ser observado na Tabela1.

Tabela 1 - Distribuição dos casos de Aids entre individuos de 15 a 19 anos de idade, segundo ano de diagnóstico e razão por sexo. Brasil, 19901999*.

\begin{tabular}{|c|c|c|c|}
\hline \multirow{2}{*}{$\begin{array}{c}\text { Ano de } \\
\text { Diagnóstico }\end{array}$} & \multicolumn{2}{|c|}{ Sexo } & \multirow{2}{*}{ Razão } \\
\hline & Masculino & Feminino & \\
\hline 1990 & 234 & 75 & $3 / 1$ \\
\hline 1991 & 329 & 75 & $4 / 1$ \\
\hline 1992 & 257 & 98 & $3 / 1$ \\
\hline 1993 & 223 & 101 & $2 / 1$ \\
\hline 1994 & 228 & 125 & $2 / 1$ \\
\hline 1995 & 208 & 125 & $2 / 1$ \\
\hline 1996 & 165 & 121 & $1 / 1$ \\
\hline 1997 & 173 & 146 & $1 / 1$ \\
\hline $1998 / 99$ & 195 & 197 & $1 / 1$ \\
\hline Total & 2012 & 1063 & $1 / 1$ \\
\hline
\end{tabular}

Assim, embora o número de casos no sexo masculino, no período 1990-99, seja bem mais elevado (2012) do que no sexo feminino (1063), no período reportado, a tendência de crescimento dos casos entre mulheres veio sendo mais rápida. Esse fenômeno é conhecido por "feminização" da epidemia, e é acompanhado por um número cada vez maior de crianças atingidas.

Quanto a casos novos no país, até dezembro de 2002, foram notificados 9.495, dos quais, 6.031 verificados em homens e 3.464 casos em mulheres $(1,7 \%)$. A transmissão do HIV entre mulheres se dá, em sua maioria, pela via sexual $(86,2 \%)$, seguida pelo uso de drogas injetáveis $(12,4 \%)$, de acordo com dados do Ministério da Saúde (MS 1999c, 2000). 


\subsection{Medicalização da Aids}

Inúmeros estudos e pesquisas, realizados nos últimos anos, mostram que as pessoas têm informação sobre a existência do HIV/Aids e têm opinião formada a respeito, coincidentemente, ou não, semelhante ao que diz a ciência, os órgãos governamentais ou os ativistas.

Pela complexidade de ações que implica, a infecção pelo HIV/Aids acaba por impor desafios e coloca em questão, não apenas o sistema de saúde, mas o próprio sistema social.

São tantas as questões que se avizinham, se sobrepõem e se interpenetram nos campos HIV e da Aids que, sem dúvida alguma, consideramos a contaminação pelo HIV e a epidemia da Aids, dentro da tradição das ciências sociais, um fator social total (PARKER 1994, p. 14).

Em um recorte do campo social, é possivel que, em nenhum outro lugar, seja tão visível o impacto da Aids, quanto nos serviços de saúde, responsáveis por seu tratamento.

Serviços inteiros transfiguram-se para poder dar conta da nova doença: onde se atendiam doenças infecciosas há muito conhecidas e categorizadas passou-se a conviver com o desafio trazido por pacientes com infecções múltiplas; 0 que tinha sido curável (pneumonia, tuberculose, diarréia) passou a ser incurável; o que era raro (como o sarcoma de kaposi) passou a ser comum; o que era conhecido e diagnosticado passou a ser de difícil diagnostico e sem respaldo do saber médico; (...) fluxos financeiros inesperados provocaram diferenciações nos serviços, criando ilhas de primeiro mundo dentro de um panorama de degradação e carência. (Parker 1994, p. 15).

No campo da saúde, a epidemia vem evidenciar déficits, conflitos e contradições que marcam a história das políticas públicas de saúde, no Brasil. Para além de um fato médico é, portanto, um fato social e um fato político (PIMENTEL 2001). 
Contraditoriamente a esse enfoque, no discurso produzido por instituições de saúde pública, a respeito da epidemia, a Aids continua sendo tomada como uma questão médica e tratada nesse âmbito. Apenas muito recentemente, a abordagem da Aids, como um evento social complexo e multifacetado, vem sendo integrada à cultura médico-administrativa (PIMENTEL 2001).

Ao se medicalizar a epidemia de HIV/Aids, obscurecem-se suas raízes sociais: põe-se de lado sua associação com a pobreza e com a desigualdade social e de gênero, ignoram-se a dimensão e o peso das representações sociais e individuais, as especificidades de cada grupo populacional e a complexidade das interações sociais; negam-se e negligenciam-se direitos humanos básicos (PIMENTEL 2001).

Toda doença é uma experiência inerente à condição humana e só deixa de ser um evento dotado de neutralidade, à medida que the são atribuidos significados que, por sua vez, variam de acordo com os determinantes sociais e culturais de cada época.

Em sua dissertação de mestrado, BETINI (1997) relata o paralelo entre o medo, a informação e a mudança de comportamento frente ao HIV, analisado por Venturi (1992), em estudo baseado nos resultados de uma série de surveys realizados pelo Instituto de Pesquisa Data Folha, nos anos de 1985, 1987 e 1990.0 objetivo desse estudo foi o de verificar a presença, ou não, do medo na população, diante do risco de contaminação pelo HIV, os motivos do medo, o conhecimento sobre as vias de transmissão e a provável mudança de comportamento. Tinha-se, como pressuposto, que o medo era gerado pela falta de conhecimento: supunha-se que o aumento da informação sobre a epidemia representaria uma redução do medo. Porém, constatou-se que o temor de contrair o HIV cresceu simultaneamente ao aumento da consciência sobre a síndrome e formas de evitá-la, mais do que isso, nos últimos anos, o medo da AIDS aumenta, não obstante a assimiliação de mudança de comportamento por uma parcela significativa da população (Venturi, cit. BETINI 1997).

Seguindo, ainda, a linha de discussão de BETINI (1997) sobre a pesquisa realizada, e da qual estamos tratando, ao se cruzarem as respostas obtidas, verificou-se que a taxa de medo subira, de $66 \%$ para $71 \%$, entre aqueles que se 
consideravam bem informados, ficando estável no grupo dos "desinformados" ( $70 \%$ e 68\%), indicando que, no caso da AIDS, "a lógica do medo é outra, quem conhece teme, ao menos, tanto quanto quem ignora".

O autor segue questionando por que isso acontece, e se a informação está sendo passada de forma inadequada, ou se realmente não se tem um conhecimento absoluto sobre o tema. Diz, ainda, que nisto a AIDS desafia a ciência do nosso tempo e propicia que, mesmo mediante o acesso à informação, o medo persista.

A resposta para parte desses questionamentos está na própria pesquisa, que constata, em primeiro lugar, a dimensão da fatalidade que o fato de ser portador do vírus HIV representa na vida de uma pessoa. Com base nos resultados dos surveys, o autor pôde observar que "a consciência da letalidade da síndrome" apresenta-se como princípio gerador do medo de contraí-la; em segundo lugar, a resposta para o referido temor advém da marginalização dos doentes e portadores, principalmente, no que se refere à questão da falta de assistência médica e discriminação social e familiar, e, ainda, o medo em função dos riscos com transfusões de sangue e contaminação hospitalar.

Por outro lado, o conhecimento científico sobre a Aids e formas de transmissão, apesar de todo avanço conseguido na área, não constitui um conhecimento "fechado".

A autora continua refletindo, a partir dessa pesquisa, dialogando com outros teóricos, que destacam a importância de estratégias de Saúde Pública que favoreçam, não só a informação, mas, também, a mudança de comportamentos de risco. Assinala que, ao apresentar a importância da informação, enquanto componente de prevenção, torna-se indispensável o acesso dos indivíduos à mesma (informação), para a redução da vulnerabilidade. Se, anteriormente, havia uma preocupação com os "grupos de risco", atualmente esta se generalizou e o próprio conceito foi substituído pelo de vulnerabilidade, ou ainda, de comportamento de risco, adotados pelo Ministério da Saúde.

Acrescenta, ainda, que a possibilidade da prevenção na redução da vulnerabilidade à infecção pelo HIV/Aids baseia-se em três elementos- chave: informação/educação; serviços de saúde e sociais e um ambiente social de apoio. 
Em relação ao primeiro (informação/educação), BETINI (1997), apoiando-se em Mann e col.(1993) considera que, apesar de representar um elemento chave, após análise de experiências preventivas baseadas na disseminação da informação, esta isoladamente não proporciona uma mudança efetiva de comportamento, uma vez que a forma como indivíduos assimilam a informação é muito diversificada.

Segundo esse autores, "é arriscado confiar apenas na informação, as interpretações incorretas e os mal-entendidos são comuns nos programas de informação sobre AIDS e servem como barreiras à adoção do comportamento preventivo".

E acrescentam que as próprias mensagens veiculadas podem propiciar diversas interpretações, principalmente, quando essas são ambíguas. Citam, como exemplo, aquelas que se referem à troca de "líquidos corporais", que podem ser interpretados, tanto como esperma e sangue, como também, suor e saliva.

Deve ser levada em consideração, ainda, a diversidade da população, tanto no que se refere ao grau de instrução, quanto às práticas sexuais; mensagens para grupos específicos e com linguagem diferenciada podem alcançar melhores resultados.

Quanto aos canais da disseminação da informação, Mann e col (1993), citados por BETINI (1997), ressaltam que "canais interpessoais", como aconselhamento, são mais eficazes no sentido de se obter uma mudança de comportamento. Em contraposição, a mídia, que "conscientiza e marca acontecimentos", pode atingir um público maior, sem representar, necessariamente, uma mudança de comportamento.

O segundo elemento apresentado por Mann e col. (1993) refere-se aos serviços sociais e de saúde, enquanto complemento à informação/educação, que podem auxiliar no sentido de transformar a informação recebida em comportamento preventivo, como, por exemplo, a testagem e o aconselhamento.

Para eles, "os serviços de apoio incluem provisão de informações, assistência e produtos, através de redes governamentais, não governamentais e privadas". Sua eficiência aumenta à medida que aumenta a participação dos indivíduos e das comunidades aos quais se destinam o projeto e sua implementação. "A eficácia da resposta ao HIV/AIDS depende do grau de acesso 
geográfico e financeiro dos serviços, criados para atender às necessidades da comunidade; do grau de receptividade do ambiente (qualidade de contato interpessoal, confiança, tolerância, compaixão): da qualificação do pessoal responsável e, por fim, do tempo de duração desses serviços. Portanto, os serviços sociais e de saúde exigirão o uso de vários canais de comunicação, a participação de recursos humanos treinados, o gerenciamento e a coordenação eficazes e a disponibilidade contínua de recursos financeiros" (Mann e col. 1993, cit. BETINI 1997).

O terceiro elemento diz respeito ao meio ambiente adequado, estando diretamente relacionado, segundo esses autores, à expressão "conceder autonomia", ou seja, "processo através do qual os indivíduos passam a ter autonomia para determinar seu comportamento" (BETINI 1997).

\subsection{Transmissão Vertical}

O aumento da incidência da doença em mulheres gerou, em paralelo, um aumento da transmissão vertical, ou seja, da mulher grávida para seu filho, conforme mencionado anteriormente. A mãe contaminada pode transmitir o vírus para a criança durante a gestação e trabalho de parto, por via transplacentária (transmissão intra-uterina), durante o nascimento, pelo canal do parto (transmissão intraparto), ou através do aleitamento materno.

A transmissão intra-uterina é possivel em qualquer fase da gravidez, mas é mais freqüente no primeiro trimestre. As infecções ocorridas no período intrauterino não têm sido associadas a malformações fetais. $O$ risco de transmissão do HIV da mãe para o filho pode ser reduzido em até $67 \%$, mediante o uso de AZT durante a gravidez e no momento do parto, associado à administração da mesma droga ao recém-nascido, por seis semanas. A maneira de impedir a transmissão pelo leite materno é através do uso de leite artificial ou de leite humano, processado em bancos de leite, que realizem triagem das doadoras (MS 2000; MONTAGNIER 1996; PARKER e GALVÃO 1996). 


\subsection{Transmissão Vertical nas Regiões do Brasil e no Estado do Espírito Santo}

A transmissão vertical é a principal via de infecção, pelo HIV, em crianças, tendo sido responsável, no Brasil, por mais de $80 \%$ do total de casos de Aids em menores de 13 anos, no período de 1983-1999, e, por mais de $90 \%$, considerando apenas o período de 1998 a agosto de 1999. Os casos de transmissão vertical corresponderam a 2,7\% do total geral de casos notificados, até agosto de 1999 (MS 2000; MONTAGNIER 1996; PARKER e GALVÃO 1996).

Segundo o Boletim Epidemiológico, de março a maio de 1999, MS (1999b), o número de gestantes infectadas pelo HIV, no Brasil, foi de cerca de 13 mil, considerando-se apenas as idades de 15 a 49 anos. Dessas mulheres infectadas, apenas $38,5 \%$ foram identificadas e receberam tratamento com AZT durante 0 parto (MS 2000; MONTAGNIER 1996; PARKER e GALVÃO 1996).

De acordo com a fonte citada, acima, o nível de escolaridade, como indicador da situação sócio-econômica, revela um crescimento do empobrecimento, juntamente com a mudança do perfil de transmissão. Verifica-se uma diminuição no nivel de escolaridade, para ambos os sexos, sendo que as mulheres apresentaram menor grau de escolaridade, desde 0 início da epidemia.

Dados de 1987 mostram que cerca de $40 \%$ dos homens declararam ter até $1 .^{\circ}$ grau, enquanto entre as mulheres, essa proporção correspondeu a 76\%. Dez anos depois, em 1997, 70\% dos homens e $81 \%$ das mulheres apresentaram essa mesma condição de escolaridade. Esse fato, evidentemente, vem influenciando o contexto em que se dá a transmissão materno-infantil do HIV no Brasil (MS 2000; MONTAGNIER 1996; PARKER e GALVÃO 1996).

Com base em dados disponiveis do Sistema de Informação de Agravos de Notificação - SINAN, foram notificados, no periodo de 1983 - 1999, um total de 5.778 casos de Aids em crianças menores de 13 anos (MS 1999d), observando-se que $80 \%$ dos casos se deram pela via de transmissão vertical (Figura 4). 
Figura 4 - Proporção de casos de Aids em menores de 13 anos, segundo categoria de transmissão. Brasil, 1983 - 1999.

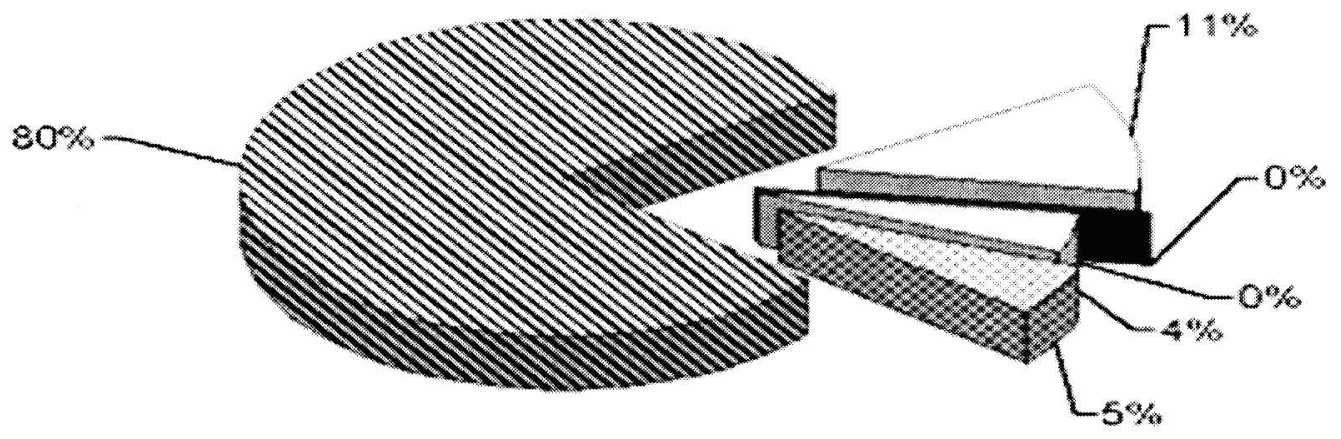

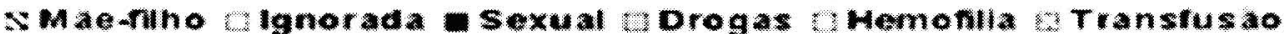

Fonte: CN-DST/Aids - Ministério da Saúde,1999.

A transmissão vertical ocorreu, em maior freqüência, do final da década de 80 até a metade da década de 90, declinando em seguida. Depois de 1996, houve uma redução no número de casos, provavelmente, relacionada a um possível impacto das intervenções com o uso de antiretrovirais (PACTG 076) e outras terapêuticas, na gestação e no recém-nascido; e também, ao atraso da notificação nos anos seguintes, como pode ser observado na Figura 5 (MS 1999a, 1999d, 2001). 
Figura 5 - Casos de Aids em menores de 13 anos, segundo categoria de transmissão e ano do diagnóstico. Brasil, 1983 - 1999.

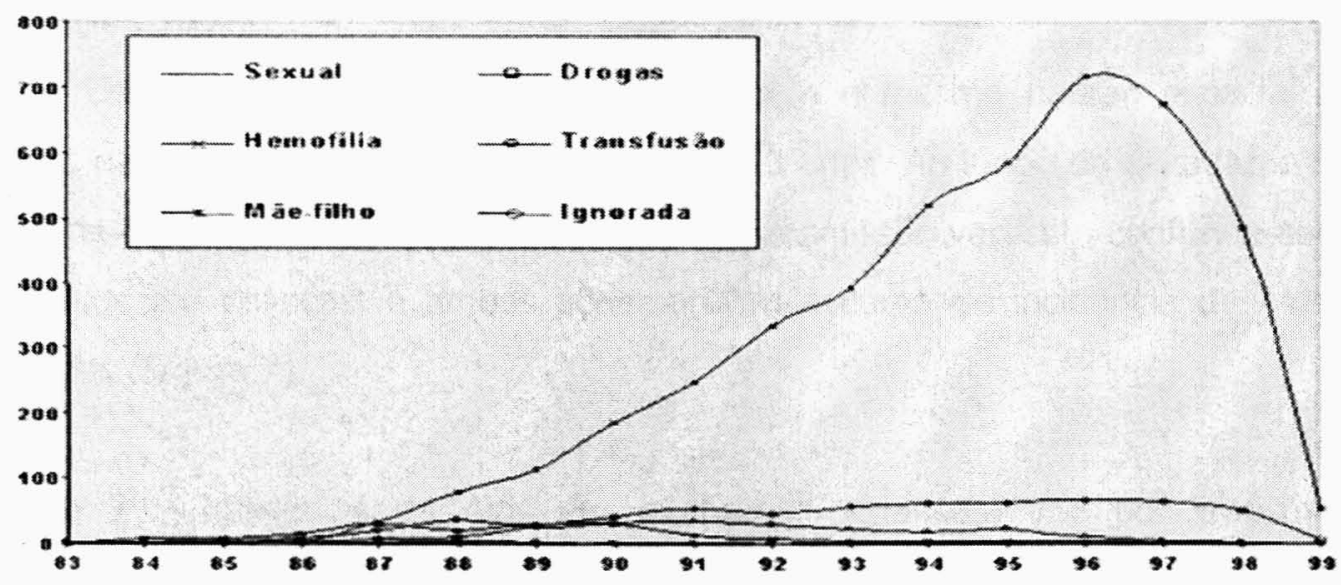

Fonte: CN-DST/Aids-Ministério da Saúde, 2000.

Quanto à distribuição geográfica, os casos de Aids pediátrica seguem os padrões gerais da epidemia. Há, desde o início, um predomínio de casos na Região Sudeste, que concentra $63 \%$ do total. Ao longo da década de 90 , a epidemia veio se expandindo na Região Sul, enquanto as regiões Nordeste, Centro-Oeste e Norte apresentaram os menores quantitativos (Figura 6).

Figura 6 - Taxa de incidência de Aids (por 100.000 hab.), segundo ano de diagnóstico e região de residência. Brasil, 1991-2002*.

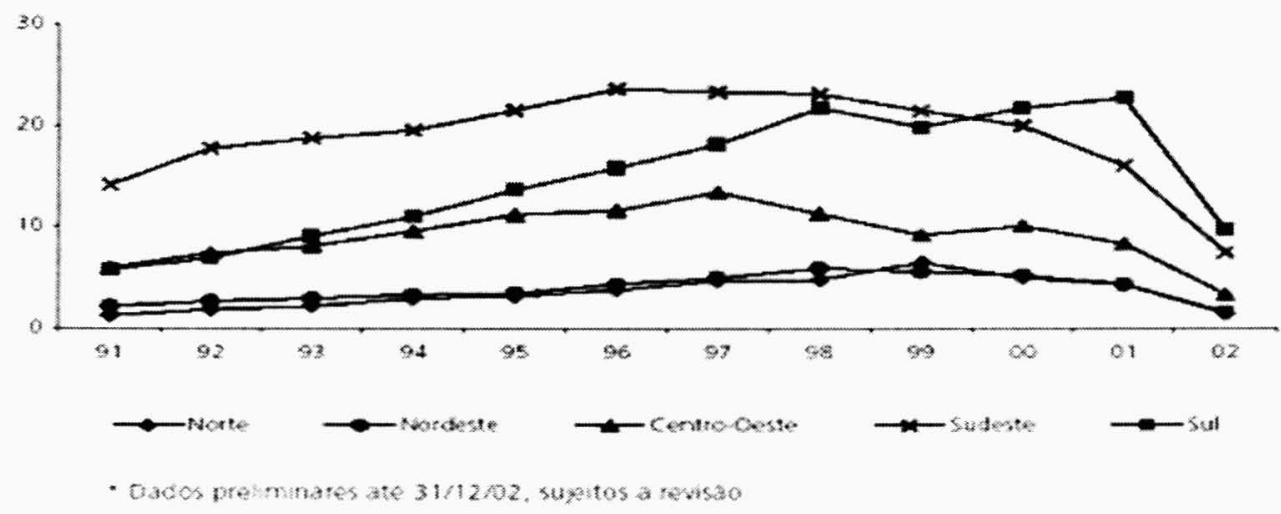

Fonte: CN-DST/Aids - Ministério da Saúde,2002. 
O primeiro caso de transmissão vertical foi notificado em 1985 , e, até agosto de 1999, foram registrados 4630 casos nesta categoria, com cerca de $40 \%$ de óbitos (MS 1999d).

Os casos de transmissão vertical seguem o mesmo padrão espacial e no tempo, para o total de casos em menores de 13 anos. Ao longo da década de 90, a curva de crescimento dos casos de Aids, por transmissão vertical, confunde-se com a de Aids em crianças, e ambas acompanham a curva de incidência de Aids em mulheres (Figura 7).

Figura 7 - Incidência da Aids em mulheres*, crianças**, e por transmissão perinatal. Brasil, 1985 - 1998/99.

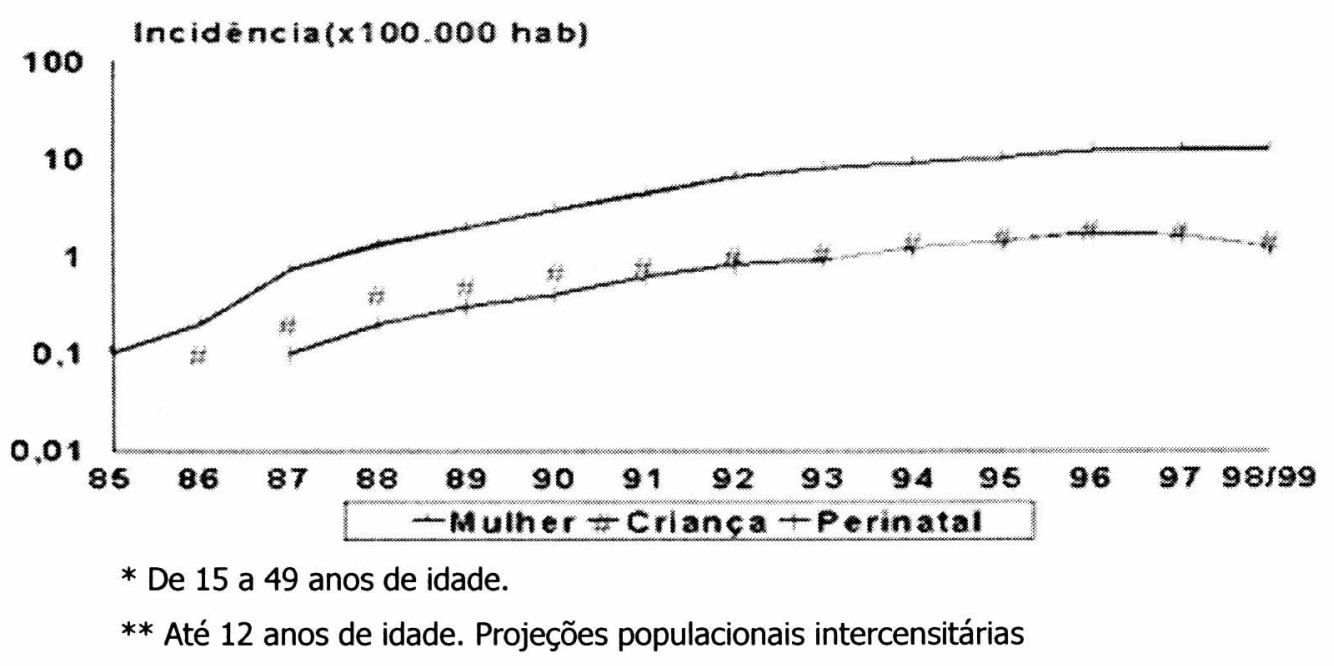

Fonte: CN-DST/Aids - Ministério da Saúde,2000.

Ao analisar a idade da criança, no momento do diagnóstico (Figura 8), foi observado que, nas regiões Norte e Nordeste $(p<0,001)$ a notificação dos casos é mais tardia. 
Figura 8 - Distribuição de idade no momento da notificação dos casos de Aids em menores de 13 anos, infectados por via vertical, segundo região de residência. Brasil, 1983 - 1999 (até agosto).

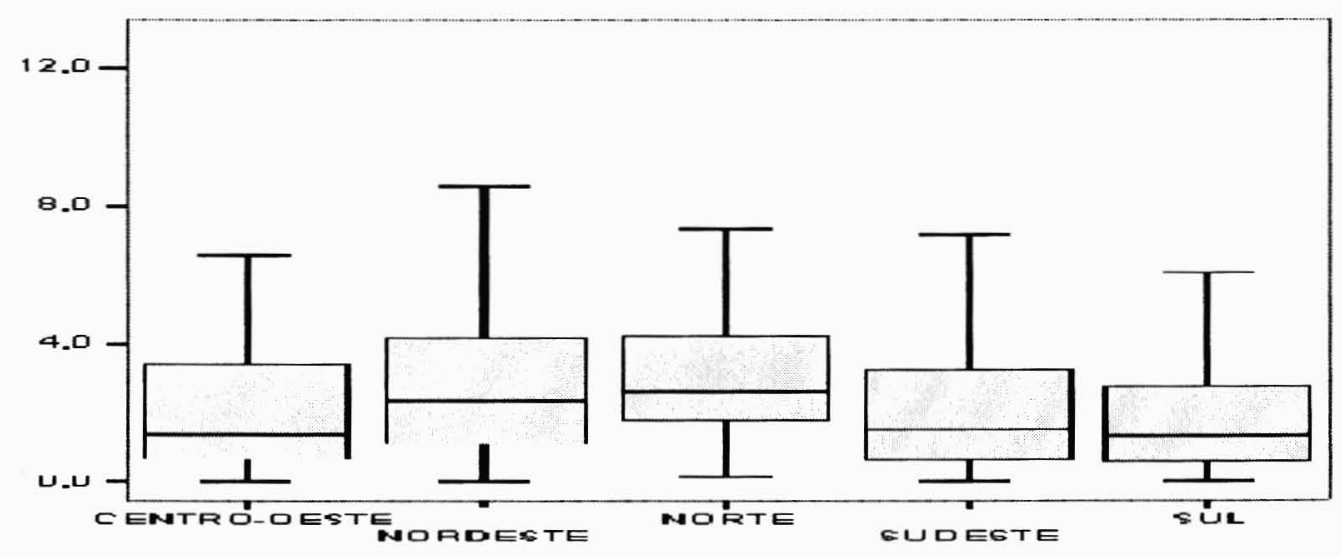

Fonte: CN-DST/Aids - Ministério da Saúde, 1999.

As razões para essas diferenças podem estar ligadas, tanto ao desempenho insuficiente da rede de serviços de saúde, nessas regiões, para detectar, diagnosticar e notificar os casos de Aids em crianças, quanto à maior prevalência de outras doenças infantis, mascarando e retardando o diagnóstico.

Segundo informações relacionadas à categoria de exposição da mãe, nota-se que, embora $47 \%$ dos casos relatem exposição sexual, como fator de transmissão, mais de 34\% não apresentam essa informação registrada na ficha. Também, há evidências sobre a exposição às drogas injetáveis em $16 \%$ dos casos notificados (Figura 9). 
Figura 9 - Proporção de casos de Aids em menores de 13 anos, infectados por via vertical, segundo categoria de exposição da mãe. Brasil, 1983 - 1999 (até agosto).
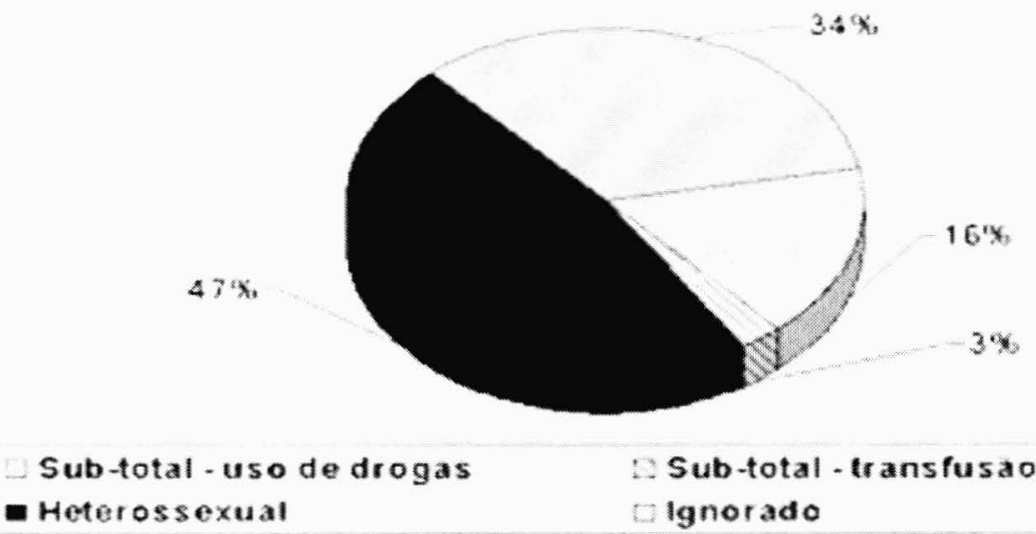

Fonte: CN-DST/Aids - Ministério da Saúde, 1999.

Quanto à exposição da mãe, nos diferenciais por região, chama a atenção o elevado percentual de ignorados, que varia de $21 \%$ na região Norte a $40 \%$ nas regiões Nordeste e Sul (Figura 10).

Figura 10 - Proporção de casos de Aids em menores de 13 anos infectados por via vertical, segundo categoria de exposição da mãe por regiões. Brasil, 1983 - 1999 (até agosto).
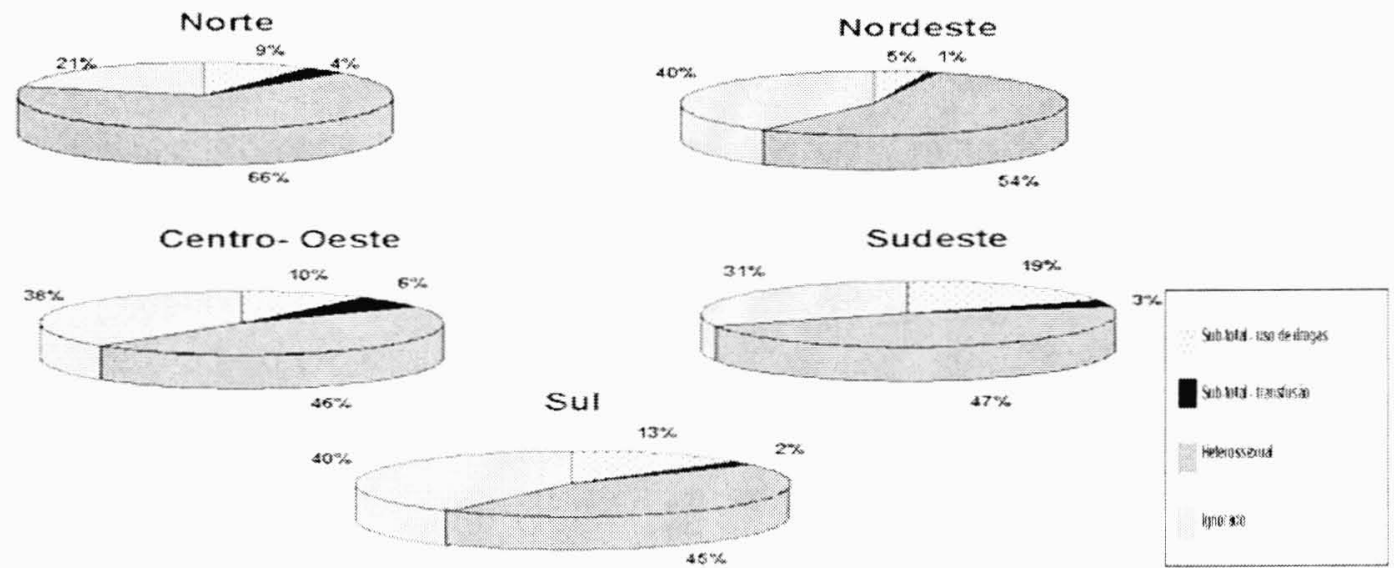

Fonte: CN-DST/Aids - Ministério da Saúde, 1999. 
Para o total de casos no país, destaca-se a parceria da mãe com usuários de drogas injetáveis (39\%); seguida de parcerias com homens HIV-positivos e com múltiplos parceiros (Figura 11).

Figura 11 - Distribuição proporcional dos casos de Aids por transmissão vertical, segundo características da parceria da mãe na categoria de exposição heterossexual. Brasil, 1993 - 1999.

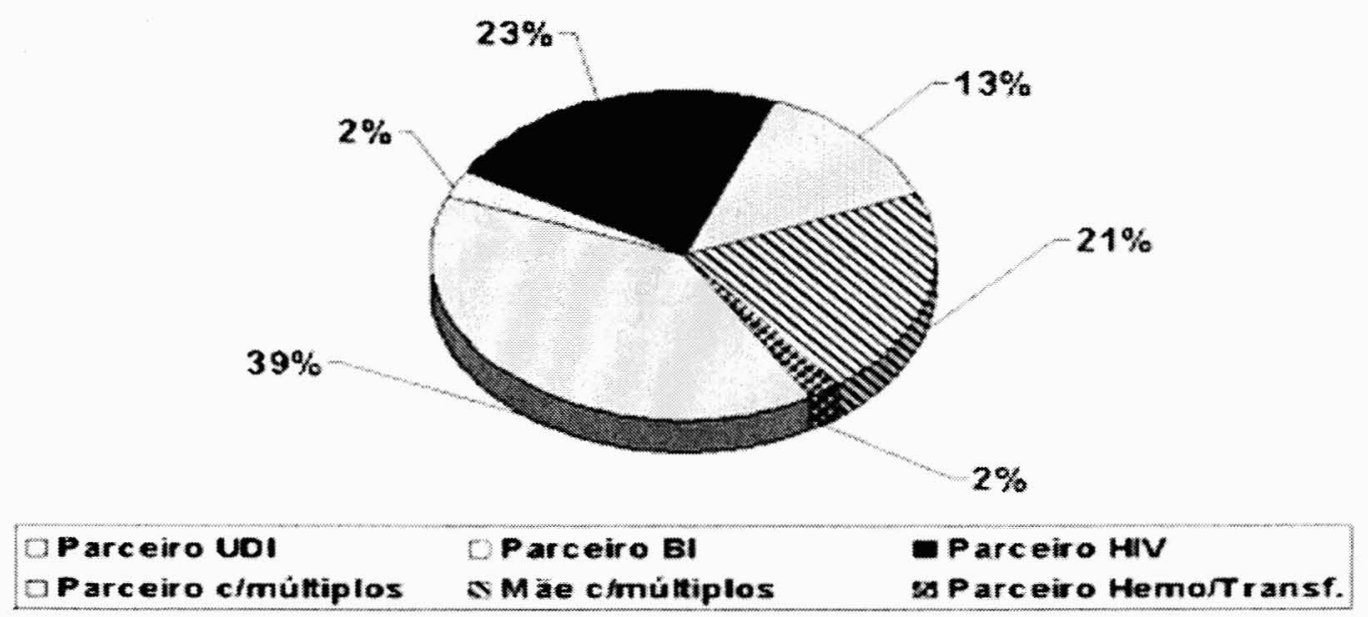

Fonte: CN-DST/Aids - Ministério da Saúde, 1999.

No preenchimento da ficha de investigação, quando não se consegue caracterizar apropriadamente o risco do parceiro, existe a possibilidade de que seja incluído no grupo dos HIV-positivos.

Existem algumas diferenças no comportamento das parcerias, por regiões. No Norte e Nordeste, por exemplo, embora predomine a exposição mãe com múltiplos parceiros (cerca de $40 \%$ ), as outras subcategorias se distribuem com percentuais semelhantes, exceto a de parceiro usuário de drogas, que na região Nordeste é pouco expressiva.

Já nas regiões Sul e Sudeste, ao contrário, a elevada proporção de parceiros usuários de drogas injetáveis destaca-se sobre os demais, e, na região CentroOeste, os grupos de parceria, usuário de drogas, HIV-positivos e múltiplos parceiros, contribuem com cerca de $25 \%$ dos casos (Figura 12). 
Figura 12 - Distribuição proporcional dos casos de Aids por transmissão vertical, segundo características da parceria da mãe na categoria de exposição heterossexual, por regiões. Brasil, 1993 - 1999

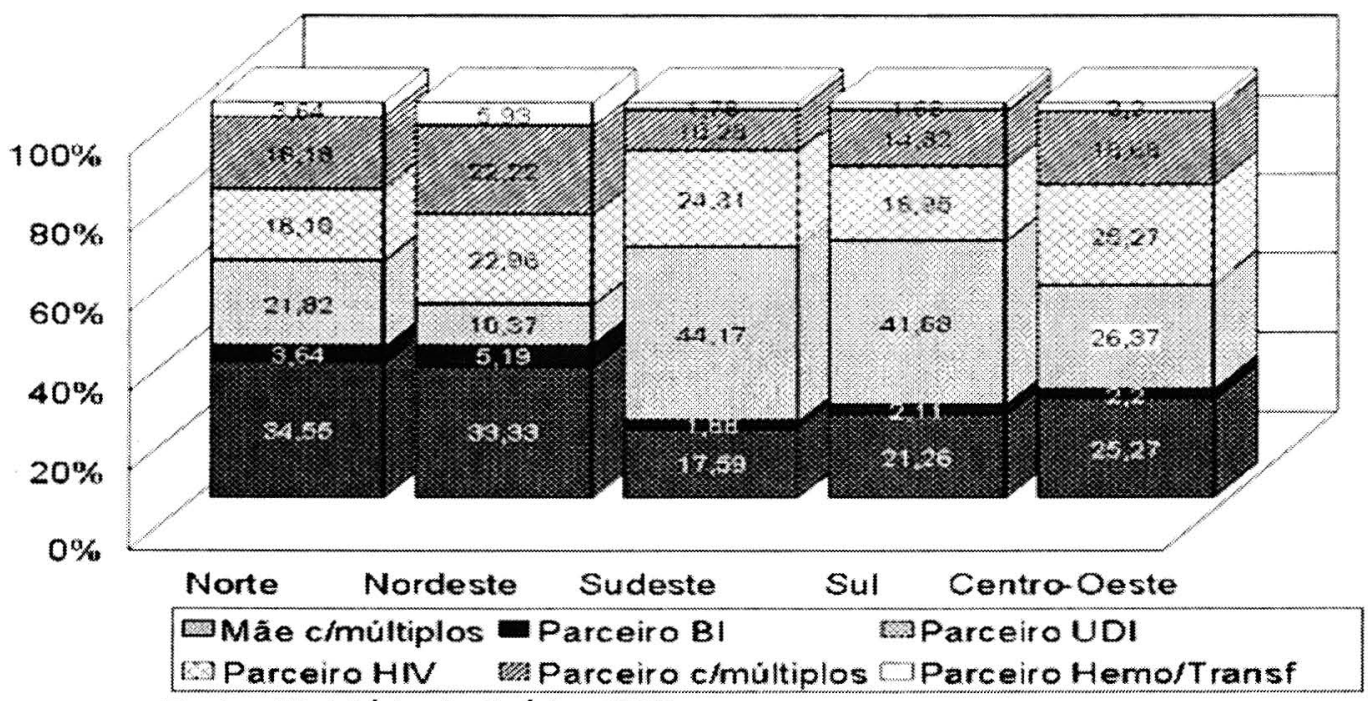

Fonte: Ministério da Saúde, 1999.

Nas capitais que apresentam as maiores taxas de incidência de transmissão vertical do país (Florianópolis, Porto Alegre, Vitória e São Paulo), na categoria de exposição heterossexual, prevalece, na transmissão vertical, o uso de drogas injetáveis, sendo que, em Vitória, o uso de drogas injetáveis é dividida com a categoria múltipla parceiros (Figura 13). 
Figura 13 - Distribuição proporcional dos casos de Aids por transmissão vertical, segundo características da parceria da mãe na categoria de exposição heterossexual, nas capitais com maiores taxas de incidência. Brasil, 1993 - 1999.

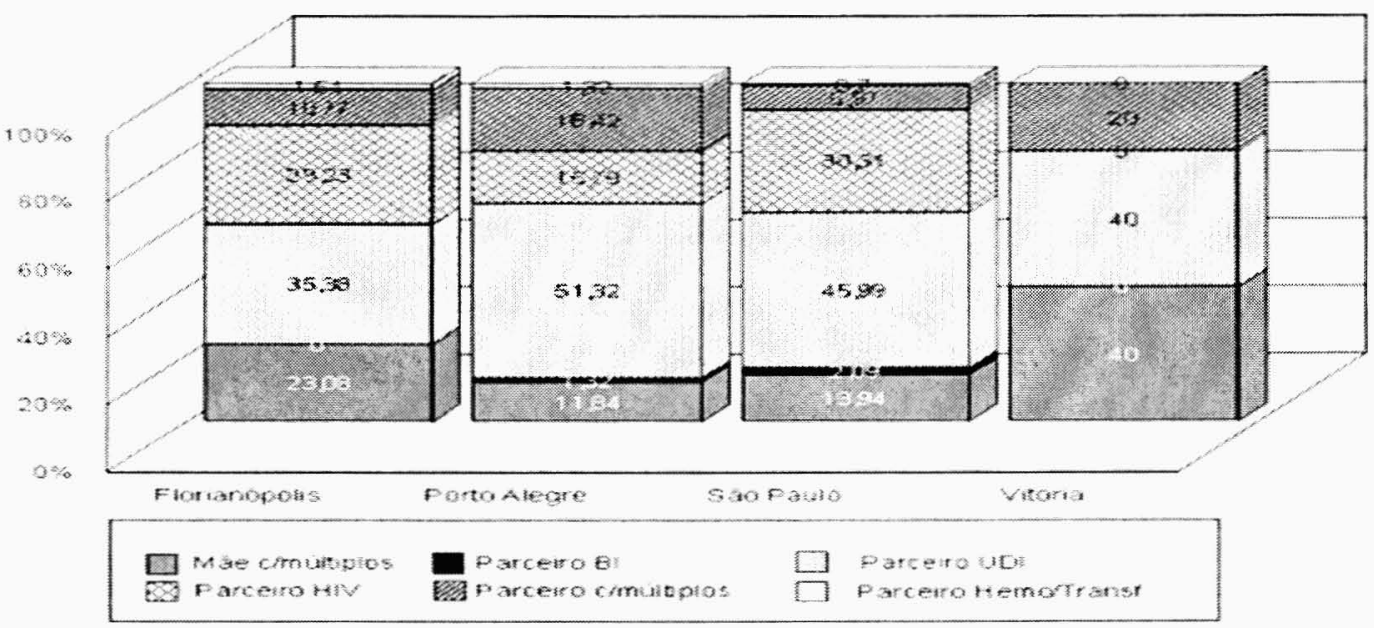

Fonte: Ministério da Saúde, 1999.

Diante do quadro exposto, pode-se dizer que o panorama atual da transmissão vertical pelo HIV, no Brasil, indica que a epidemia, até o momento, não está sob controle, embora meios para a sua prevenção estejam disponíveis. É necessário analisar, permanentemente, a evolução das características gerais dos casos e os padrões da transmissão nas diferentes regiões do país (MS 1999d).

O quadro futuro vai depender da velocidade de disseminação do vírus nos dias atuais e do número de indivíduos que possam estar transmitindo o HIV e que estarão, possivelmente, desenvolvendo Aids nos próximos anos. Conhecer o número de pessoas infectadas, sem manifestação da doença, é essencial para programar as necessidades futuras da área de saúde, no que se referem a leitos e medicamentos, e soluções aos problemas sociais decorrentes da Aids. O número de portadores do vírus, ainda, não é conhecido no país.

A Aids tem sido considerada, pela Organização Mundial de Saúde, como uma ameaça ao desenvolvimento, à coesão social e à expectativa de vida. A epidemia atinge mulheres e crianças, com especial intensidade (WHO 2000, 2002). 


\subsubsection{Perfil da Paciente Infectada}

O percentual de casos de Aids em mulheres, cujo modo de transmissão consta como ignorado, varia entre $20 \%$ e $30 \%$, sendo superior ao percentual de casos masculinos, nessa categoria. Isso pode ser explicado pelo fato de haver a orientação de apenas se registrar o modo de transmissão, quando há certeza do fator de risco. Para as mulheres, isto implica que ela afirme que seu parceiro é bissexual, usuário de drogas injetáveis ou que tem múltiplas parceiras, situaç̃es que nem sempre são de conhecimento das mulheres (CZERESNIA 1997; LANE e CODO 1984; MS 1999b, 2000; MONTAGNIER 1995; PARKE e BARBOSA 1996; PARKER e GALVÃO 1996).

A infecção, pelo HIV, atinge mulheres mais precocemente do que os homens. Considerando o período de 1996 - 2000, do total de casos notificados, na população de 13 a 30 anos, mulheres excedem aos homens, em percentuais que variam entre $8 \%$ a $10 \%$ (MS 1999b, 2000).

Em relação ao número de parceiros, pesquisas apontam que as mulheres infectadas tiveram, em média, 2 ou 3 parceiros ao longo da vida, o que desfaz 0 mito de promiscuidade, associado ã infecção pelo HIV em mulheres (MS 1999b, 2000).

No que se refere ao perfil de escolaridade, mais da metade das mulheres infectadas, com mais de 19 anos, tem até 8 anos de estudo. Em 2000, mulheres com menos de 8 anos de estudo representavam $68 \%$, contra $48,1 \%$ em homens (MS 1999b, 2000).

Os mesmos estudos mostram que, entre $50 \%$ e $80 \%$ das mulheres portadoras do HIV estão desempregadas, e $25 \%$ não têm nenhum tipo de suporte familiar ou de amigos para ajudar a lidar com os problemas decorrentes da infecção.

Segundo outro estudo, realizado em 1987, há uma grande prevalência de HIV entre mulheres presidiárias. Elas desconhecem a Aids e sua saúde reprodutiva. Pode-se dizer que a taxa de infecção entre a população presidiária é maior que a da população em geral (MS 1999b, 2000). 
Com relação às usuárias de drogas injetáveis, 0 índice de infecção caiu acentuadamente, de $31,6 \%$ para 6,9\%, no período de 1983 a 1990 . Mas, isso não significa que elas tenham deixado de constituir um grupo importante, devendo receber atenção especial. Neste grupo, geralmente, as mulheres são mais jovens que os homens e, na maioria das vezes, mostram resistência ao trabalho de prevenção (MS 1999b, 2000).

No Brasil, são cerca de 7.149 casos notificados de mulheres infectadas com a doença, causada pelo uso de drogas injetáveis. Um grande percentual dessas mulheres já é mãe, e quase a metade delas tem parceiro fixo (MS 1999b, 2000).

Profissionais do sexo, consideradas as principais disseminadoras do vírus, no início da epidemia, deixaram de ser as protagonistas na discussão sobre mulheres e Aids. A redução na taxa de HIV, entre elas, deve-se ao desenvolvimento de projetos interdisciplinares, formação de rede de informação e suporte para o seu atendimento.

\subsubsection{Binômio Gravidez/Aids}

A crescente progressão da epidemia de HIV/Aids, na população feminina, veio somar-se, no campo da saúde, a antigos e graves problemas, que marcam a atenção à saúde da mulher: uso de contraceptivos convivendo com o recurso indiscriminado à laqueadura e ao parto cesáreo, a prática do aborto, altas prevalências de DST, elevados índices de mortalidade materna (MS 2000).

Em todo o mundo, a relação Aids/mulheres trouxe, na sua esteira, o crescimento da transmissão materno-infantil - transmissão vertical - do vírus HIV e, conseqüentemente, da Aids pediátrica.

O crescimento da transmissão vertical acompanha a expansão da epidemia entre mulheres. A expansão da transmissão vertical impõe, ao já complexo cenário de enfrentamento da epidemia de HIV/Aids, a questão da gravidez. Como aponta BERER (1996), à medida que a grande maioria das mulheres soropositivas encontra-se em faixas etárias correspondentes ao período reprodutivo, e, 
considerando-se a importância da transmissão sexual na dinâmica da evolução da Aids entre a população feminina, o binômio gravidez/Aids levanta uma série de questionamentos e impasses para o campo da saúde reprodutiva: questões como a autonomia da mulher frente à sexualidade e aos direitos reprodutivos, a ilegalidade do aborto, a estruturação vertical das atividades de planejamento familiar e dos serviços de pré-natal e parto, a desarticulação entre os serviços de DST e os serviços de assistência à saúde da mulher; mobiliza, ainda, polêmicas indagações.

Em primeiro lugar, remete à discussão sobre o direito à maternidade de mulheres soropositivas, diante do risco de transmissão do vírus ao bebê. $\mathrm{Na}$ verdade, uma questão nem tão discutida assim. Mais uma vez, depara-se com uma diversidade de discursos, que refletem representações e imagens conflitantes. Por um lado, o tom das publicações médico-científicas e das políticas públicas evoca a imagem da mulher cidadã, que tem direito à livre decisão sobre sua vida reprodutiva e que deve ter asseguradas todas as condições de informação e assistência. Por outro, a imagem da "santa-mãezinha" deposita no bem estar da criança todas as razões e classifica como "irresponsável" e "egoísta" a mulher HIV+ que engravida, associando diretamente prevenção da transmissão vertical à prevenção da gravidez (BERER 1996).

Essa retórica da prevenção levanta a questão da investigação sorológica da gestante. Em praticamente todos os países, decisões éticas e políticas sobre onde, por que, como e quem testar têm causado acalorados debates. No caso de gestantes, principalmente, após as evidências da eficácia do uso do AZT na redução do risco de transmissão vertical, muito se argumenta sobre a importância do diagnóstico prévio à gravidez, ou, pelo menos, o mais precoce possível. Embora a OMS (Organização Mundial da Saúde) preconize o teste voluntário, após aconselhamento, com consentimento informado e garantia de sigilo, permanece o debate sobre o caráter dessa investigação sorológica: voluntária ou compulsória, de rotina ou seletiva. Coloca-se, ainda, a discussão sobre como conduzir às experiências subjetivas e aos direitos individuais e sociais de cada mulher (BERER 1996).

De qualquer modo, seja qual for o momento do diagnóstico de $\mathrm{HIV+}$, a relação gravidez/Aids coloca impasses para a mulher em qualquer situação: à 
mulher soropositiva cabe optar por ter, ou não, um filho no cenário da transmissão vertical; à mulher que se descobre soropositiva na gestação cabe optar por levar adiante ou interromper a gravidez. Opções, nem sempre conscientes, mobilizadoras de profundos conflitos subjetivos e pelas quais, mulheres acabam sendo responsabilizadas, solitárias e individualmente. Nesse sentido, BERER (1996) faz uma importante observação, ao criticar os termos para esse tipo de transmissão do HIV-perinatal, mãe-bebê, transmissão vertical:

São termos que culpam apenas as mulheres. É preciso dois para haver uma gravidez. Homens com HIV também são responsáveis, e seu papel, tanto antes como durante a gestação, deve ser trazido à luz. Sempre que gestantes e parturientes tiverem se contaminando através de transfusões de sangue inseguras, afetando também seus bebês, os serviços de saúde pública também estão envolvidos (BERER 1996, p. 115).

Seja qual for sua decisão, prossegue o autor, a mulher está fadada à culpa e à angústia: por abrir mão da maternidade, por conviver com a exposição de um filho aos riscos (diretos e indiretos) da Aids, por submeter-se a um aborto.

$\mathrm{Na}$ decisão de interromper a gestação, além dos problemas individuais, a mulher depara-se com restrições legais, políticas e morais no acesso ao aborto seguro. Mesmo em países em que o aborto é legal, as mulheres enfrentam a necessidade de revelar sua condição de soropositividade sujeitando-se, muitas vezes, à discriminação e recusa de atendimento por parte de profissionais e serviços de saúde. Em países em que o direito ao aborto não é reconhecido, como o Brasil, a ilegalidade e a precariedade de condições em que o aborto é realizado criam obstáculos e riscos adicionais.

Na decisão de buscar ou levar adiante uma gravidez, a mulher HIV+ tem que conviver com inúmeras dificuldades: falta de informações, dificuldades de acesso a serviços de saúde especializados que assegurem redução do risco da transmissão vertical no pré-natal, parto e puerpério, e o longo período de espera para a definição do diagnóstico do recém-nascido (aproximadamente 18 meses).

A relação gravidez/Aids remete, ainda, ao debate sobre a amamentação. $\mathbf{A}$ comprovação da possibilidade de transmissão do vírus HIV através do leite materno 
gerou um acirrado debate em torno dos riscos e benefícios da amamentação, além de sérios dilemas para as políticas de saúde pública: como proibir a amamentação quando, na maioria dos países em desenvolvimento, o aleitamento materno é a principal, senão única, estratégia de prevenção de milhares de mortes infantis, por desnutrição e diarréia? A OMS tem adotado a postura de reafirmar um apoio explícito à amamentação, recomendando que as mães soropositivas devem ter apoio e condições para optar, de maneira informada, pelo leite a ser dado a seu filho, levando-se em conta sua situação cultural e sócio-econômica. Se a opção for usar substitutos do leite, recomenda-se que os governantes tomem medidas que assegurem o acesso a substitutos adequados (BERER 1996; REA 1998).

Todas essas vivências são acompanhadas por importantes conflitos na inserção social da mulher: o medo de revelar seu diagnóstico e/ou do bebê, em função de discriminação e abandono; a discriminação por parte dos serviços e profissionais de saúde; a perda do parceiro e ou de outros filhos; a dificuldade de acesso ao mercado de trabalho; e a falta de suporte econômico e familiar (BERER 1996).

Essa lista de dificuldades e conflitos, que cercam a gravidez, no contexto da infecção do HIV/Aids, poderia ser muito mais detalhada e analisada. No entanto, as situações descritas acima dão o contorno do complexo cenário em que esse tema se desenvolve: as reproduções humanas, marcadas por representações depositadas no imaginário social e individual, ressignificadas à luz do saber da ciência e da medicina, em termos de moral/patológico e dependentes de políticas de saúde, estas formuladas a partir de controversos interesses éticos, políticos e ideológicos.

Trata-se, enfim, de um cenário em que é possivel identificar, ao mesmo tempo, movimentos de luta ativa e produtiva pela definição dos direitos reprodutivos, como condição de cidadania, e relatos de mulheres que, em todo o mundo, foram discriminadas, abandonadas, pressionadas ou coagidas a abortos, ou mesmo, a serem esterilizadas, por se apresentarem como HIV+. 


\subsection{Controle da Aids no Estado do Espírito Santo}

O Estado do Espírito Santo, cuja evolução dos casos de Aids acompanha as estatísticas nacionais, tem apresentado um grande aumento de casos de Aids entre mulheres, crianças, populações mais pobres e de mais baixo nivel de escolaridade. Dos 1.935 doentes de Aids notificados na Secretaria Estadual de Saúde do Estado do Espírito Santo - SESA (2002), a maioria é composta de indivíduos com menos de 45 anos de idade, dos quais 547 são mulheres, 126 são crianças menores de 13 anos e, entre estas, $90 \%$ dos casos decorrem de exposição perinatal. Por isso, a Coordenação Estadual DST/AIDS do Espírito Santo não tem medido esforços no combate à epidemia. E por se considerar que a redução dos números de Aids não é tarefa única do poder público, e sim, de um esforço conjunto de toda a sociedade, a característica principal das ações da Coordenação Estadual, no ano de 1999, foi a integração com os diversos programas de ação de saúde: Tuberculose; Saúde Mental; Saúde da Mulher; PACS Programa da Saúde da Família - PSF e outros. Ao lado disso, a integração com diversos setores da sociedade capixaba, para a ampla divulgação da prevenção das DST/Aids. Essa integração envolveu ações conjuntas com outras Secretarias do Estado, Sociedade Médica, Sociedades de Odontologia, Universidade, Líderes Comunitários e Organizações Não-Governamentais - ONGs (SILVA 2001, 2002).

A Secretaria de Estado da Saúde, através da Coordenação Estadual de DST/Aids, desenvolveu, no ano de 1999, vários projetos de prevenção das DST/Aids, com apoio do Ministério da Saúde, entre eles, o Projeto Aids/Escola Ensino à Distância; Projeto de Redução da Transmissão Vertical do HIV; Prevenção em Aids e Comunidades Vivendo em Situação de Pobreza; Projeto para Formação de Líderes Comunitários como Consultores em Prevenção as DST/Aids; Biossegurança em HIV e Hepatite B; Aids e Populações Confinadas; Prevenção de DST/Aids com o Programa de PACS/PSF; e o Projeto de Aids e Drogas. Em 1999, conseguiu-se cadastrar e oficializar, no Ministério da Saúde, as ONGS Casa da Esperança, ASSICA e Casa Sagrada Família, bem como os Serviços de Atendimentos Especializados em Aids (SAE) do Hospital das Clínicas, do Hospital Infantil N.S. da Glória e do Município da Serra. Além disso, incentivou-se a criação de Coordenações 
Regionais e Municipais de DST/Aids, recebendo o registro da Coordenação Regional de Aids de Colatina e de, aproximadamente, 30 Coordenadores Municipais (SILVA 2001, 2002).

Ainda, em 1999, foi criada e oficializada a Câmara Técnica de DST/Aids do Estado do Espírito Santo, em que todos os serviços de DST/Aids do Estado estão representados, além dos setores gestores da SESA, Laboratórios e ONG's. Posteriormente, em 18 de novembro de 2001, o Governo do Estado sancionou a Lei Estadual $n^{0} 126$, que versa sobre a obrigatoriedade do oferecimento de testes antiHIV para toda gestante que faça pré-natal na rede pública de saúde, complementada pela Portaria $n^{\circ} 176$, que obriga a aquisição e realização dos testes anti-HIV nos laboratórios da rede Municipal, Hospitais Públicos e Conveniados ao SUS, que ofertam os Serviços de Pré-natal. Com essas ações, o Projeto de Redução da Transmissão Vertical do HIV, executado pela Coordenação Estadual de DST/AIDS, desde fevereiro de 1999, ficou fortalecido, permitindo cobrança de atitudes concretas para evitar que crianças nascessem infectadas pelo vírus.

Demonstrou-se que, até dezembro de 1998, o Laboratório Central - LACEN, realizava 500 testes anti-HIV por mês e, em dezembro de 1999, foram realizados 5.700/mês, atendendo a demanda da Grande Vitória e de diversos municípios do interior que ainda não haviam se estruturado para realizar seus próprios exames. Outros fatos importantes, que marcaram o ano, foram a oficialização do Serviço de Referência de Hematologia, criado no serviço de gastroenterologia do Serviço de Doenças Infecciosas - HUCAM, e a criação dos serviços de referência para atendimento dos acidentes de trabalho de profissionais de saúde com material pérfuro-cortante, através do Projeto de Biossegurança em HIV/Hepatite B, nos serviços de referência de Aids da Grande Vitória e no interior do Estado, tendo sido treinados e oficializados, para atendimento, os municípios de São José dos Calçado, Colatina, São Mateus, Cachoeiro do Itapemirim, Barra de São Francisco, Vila Velha, Linhares e Aracruz (SILVA 2001, 2002).

No cenário nacional, naquele mesmo ano, 1999, contou-se com o apoio da Coordenação Nacional de DST/Aids - Ministério da Saúde. Inclusive, além da aprovação de vários projetos, na última Reunião Nacional de Coordenadores Estaduais e Municipais do Programa de DST/Aids, realizada no Rio de janeiro, em 
dezembro/99, foi criada a Comissão Nacional de Gestão de Programas de DST/Aids, para propor estratégias de pactuação do processo de descentralização das ações no âmbito do SUS, aprimorando a definição de papéis de cada esfera de governo, promovendo a institucionalização e a sustentabilidade dos Programas de DST/Aids, subsidiando as Comissões Tri e Bipartites para a tomada de decisões com relação as DST/Aids, propondo e pactuando estratégias para o aprimoramento da gestão e das ações de prevenção e controle das DST/Aids (SILVA 2001, 2002).

A assistência ao portador de HIV/Aids evoluiu muito nos últimos anos, principalmente, se considerar que, nos serviços públicos, a paciente conta com acompanhamento médico e psicossocial de equipes multiprofissionais em seis Serviços de Referência na Grande Vitória e em quatro municípios do interior (SAES), com acesso gratuito e garantido (SILVA 2001, 2002).

Entre os serviços oferecidos, podem ser citados: testagens (CTA - Centro de Testagem e Aconselhamento); serviços de internação por 12 horas aos que necessitam apenas fazer uso diário de medicamentos (HD - Hospital-Dia); exames diversos essenciais, incluindo Contagem de Linfócitos CD4/CD8 e Carga Viral; e equipe multiprofissional, que vai até a residência do portador de HIV/Aids, sem condições de locomoção (ADT - Assistência Domiciliar Terapêutica), cujo atendimento era restrito aos usuários do Serviço de Doenças Infecciosas - HUCAM e que, em 1999, foi ampliado aos da Santa Casa de Misericórdia de Vitória (SILVA 2001, 2002).

Incrementou-se a implantação do sistema logístico de distribuição de preservativos, incluindo orientação das Secretarias Municipais de Saúde, na elaboração de projetos de prevenção das DST/Aids e, ao mesmo tempo, estimulação ao desenvolvimento de iniciativas voltadas para a educação no âmbito dos municípios.

Tem-se consciência de que a prevenção, ainda, é o melhor remédio contra a infecção HIV/Aids, sendo, portanto, ação importante que exige, inclusive, recursos muito menores. O elemento principal para a realização da prevenção é "pessoa qualificada e preparada" para abordar a questão com os diversos segmentos da população. Hoje, sob a ação da Coordenação Estadual, ações de prevenção estão presentes em, aproximadamente, $90 \%$ dos municípios e decorrem do trabalho 
efetivo de capacitação das equipes municipais, desenvolvido por equipe da Secretaria Estadual de Saúde. Realizaram-se diversos treinamentos, sempre oferecidos a todos os municípios. O saldo final foi de 1600 profissionais de saúde de todo o Estado treinados nas diversas áreas de assistência e prevenção. Professores de renome, de vários Estados da Federação, contribuíram para a alta qualidade do treinamento. Vários profissionais participaram de congressos e cursos de âmbito nacional e do próprio Ministério da Saúde, para que pudessem conhecer e aplicar, no atendimento ao paciente, o que há de mais recente e atual, publicado sobre Aids e sua prevenção. Realizaram-se, durante o período de agosto a novembro de 2002, campanhas sobre prevenção da Aids, não somente pela televisão, mas também por meio de jornais e rádios AM e FM, com abrangência de divulgação em todo o Estado (SILVA 2001, 2002).

No último Boletim Epidemiológico, do ano de 1999, foi publicada a disposição de todos os Secretários Municipais e da sociedade organizada para continuarem a luta e a assumirem, como principal objetivo para o ano de 2000, a redução da transmissão do vírus da Aids de mãe para filho, em um esforço conjunto, para que toda grávida realizasse seu pré-natal com qualidade, tendo seu direito garantido, e que as informações sobre a prevenção da doença continuassem sendo amplamente divulgadas a todos os setores da população do Estado (SILVA 2001, 2002).

Desde 1994, a comunidade científica mundial conhece a possibilidade de reduzir, de $30 \%$ para $8 \%$, as chances de um recém-nascido - RN de mãe HIV+ nascer com o vírus HIV (Protocolo ACTG 076). Essa conduta funciona como uma "vacina", com 70 \% de eficácia contra a Aids para a criança (SILVA 2001, 2002).

Em notas oficiais de julho de 1999, o Ministério da Saúde - MS estimou que havia 10 mil gestantes infectadas pelo HIV em todo o Brasil e que, apesar da preconização de uma rotina, desde dezembro de 1996, disponibilização de testes anti-HIV para toda grávida atendida na rede pública de saúde e de AZT para toda gestante HIV+ e seu recém-nascido, tais condutas não têm sido utilizadas pelos médicos (SILVA 2001, 2002).

O Ministério da Saúde adotou, como prioridade para o ano de 1999, a prevenção da Aids em mulheres e crianças. O principal objetivo do Plano Operativo 
Anual da Coordenação de DST/Aids (POA I AIDS II) é que $100 \%$ das gestantes atendidas na rede pública de saúde realizem a sorologia Anti-HIV, e que toda grávida soropositiva use AZT na gestação e no parto, sem amamentar seu recémnascido, e que ele também use AZT. Se houvesse adesão integral dos profissionais de saúde e das gestantes, poderiam ser evitados milhares de novos casos de Aids, por ano, em crianças. Essa é uma grande chance para prevenção da doença, além de ser uma forma de contribuir para redução dos índices de mortalidade infantil, uma vez que a taxa de letalidade da Aids em crianças menores de 5 anos é de $41 \%$ (SILVA 2001, 2002).

Portanto, não é aceitável que, existindo recursos na rede pública, crianças continuem nascendo infectadas pelo HIV.

Segundo a Portaria n. 0 993, de 04/09/2000, o Ministério da Saúde tornou obrigatória a notificação de gestantes em que fosse detectada a infecção pelo HIV (diagnóstico laboratorial de infecção pelo HIV em conformidade com as normas e procedimentos estabelecidos pelo Ministério da Saúde). Da mesma forma, tornou obrigatória a notificação das crianças nascidas de mães infectadas, ou que tenham sido amamentadas por mulheres infectadas pelo HIV. Para cumprir esse objetivo, foi criada a "Ficha de Investigação de Gestantes HIV+ e Crianças Expostas" para a notificação padronizada, e que pode ser conseguida em qualquer maternidade (SILVA 2001, 2002).

Diante de tudo isso, consideramos oportuno e relevante proceder ao estudo da situação epidemiológica da transmissão vertical de HIV no Estado do Espírito Santo, no período de 1999 a 2002 e, com isso, oferecer subsídios para o aprimoramento do trabalho na área. 


\section{OBJETIVOS}

\subsection{Objetivo Geral}

Este estudo tem por objetivo geral analisar o perfil epidemiológico da transmissão vertical do HIV no Estado do Espírito Santo, no período de 1999 - 2002.

\subsection{Objetivos Específicos}

a. Verificar tendências na taxa de transmissão vertical do HIV no Estado do Espírito Santo, no periodo de 1999 - 2002.

b. Identificar o perfil da gestante infectada.

c. Identificar o número e proporção de gestantes e recém-nascidos que fizeram uso da terapêutica para prevenção da Aids pediátrica, no período do estudo.

d. Verificar o número e proporção de crianças que foram negativadas, no período do estudo. 


\section{MATERIAL E MÉTODO}

Neste capítulo, são apresentados os procedimentos metodológicos que permitiram fazer emergir os elementos constitutivos dos aspectos da transmissão vertical HIV+/Aids.

\subsection{Tipo de Estudo}

Trata-se de um estudo descritivo, baseado em dados secundários (Fichas de Notificação/Investigação Gestantes HIV+ e Crianças Expostas), cedidas pela Secretária Estadual da Saúde do Espírito Santo - SESA.

\subsection{Local do Estudo}

O Estado do Espírito Santo localiza-se na Região Sudeste do Brasil, que, sendo a mais desenvolvida do País, abriga a população do território nacional de maior poder aquisitivo.

As principais cidades são: Vitória, Vila Velha, Cariacica, Serra, Cachoeiro de Itapemirim, Linhares, Colatina, Guarapari, São Mateus e Nova Venécia.

Vitória, capital do Estado, fica no meio da costa brasileira, no sentido nortesul, a $521 \mathrm{~km}$ ao norte da cidade de Rio de Janeiro (RJ), a $882 \mathrm{~km}$ da cidade de São Paulo (SP), e a 524Km de Belo Horizonte (BH). A cidade é cortada pela BR 101, que atravessa o Estado do Espírito Santo, em direção norte-sul, dando acesso ao Rio de Janeiro (RJ), São Paulo (SP), Salvador (BA), entre outros, e pela BR - 262, que liga Vitória a Belo Horizonte e até Corumbá, no Mato Grosso do Sul (DEPARTAMENTO ESTADUAL DE ESTATÍSTICA 2001; IBGE 2001; FUNDAÇÃO IBGE 2002).

Com uma posição geográfica privilegiada, o Estado do Espírito Santo constitui uma excelente opção para investimentos, devido à sua proximidade dos centros mais dinâmicos e desenvolvidos do País e à sua integração no mercado 
internacional, proporcionada por um complexo portuário dos mais eficientes do Brasil. É interligado a uma eficiente malha ferroviária, o que faz do Espírito Santo uma das principais vias nacionais de acesso aos mercados interno e externo, integradas a todo o País e à América do Sul, através de três grandes eixos de transportes.

A importância dessa localização estratégica fica evidenciada quando se constata que, num raio de mil quilômetros, a partir da capital do Estado, a cidade de Vitória, encontram-se os principais centros consumidores do País, em uma área detentora de $80 \%$ do PIB nacional, representando um mercado consumidor de mais de 60 milhões de pessoas. Além disso, seu complexo portuário, interligado a um eficiente sistema de rodovias, ferrovias e aeroporto, fazem do Estado um importante centro para logística no País (DEPARTAMENTO ESTADUAL DE ESTATÍSTICA/ ES 2001; FUNDAÇÃO IBGE 2002; IBGE 2001).

A economia espirito-santense passou por uma transformação, sem precedentes, no início da década de 70. Caracterizada, nessa época, pela predominância do setor primário, representado pela monocultura cafeeira, foi atingida, a partir de então, por um processo de industrialização, amparado na instalação de grandes plantas industriais, como a Companhia Vale do Rio Doce CVRD, Samarco Mineradora, Aracruz Celulose e a Companhia Siderúrgica de Tubarão - CST, entre outras. Após o estabelecimento desses setores, o Estado montou sua estratégia de industrialização e, hoje, apresenta uma economia cada vez mais diversificada e integrada (DEPARTAMENTO ESTADUAL DE ESTATÍSTICA/ ES 2001; FUNDAÇÃO IBGE 2002; IBGE 2001).

A mudança de padrão econômico do Estado para o complexo industrialexportador e importador redefiniu o contorno da cidade de Vitória, deslocando seu eixo para a ampliação e diversificação de uma rede de serviços, ligados ao comércio exterior e à distribuição de produtos. Essas são características do novo paradigma da era da globalização.

O Estado do Espírito Santo possui uma população de 3.023.619 habitantes, estando $78 \%$ localizados nas zonas urbanas e $22 \%$ nas rurais, e seu PIB per capta é de US $\$ 4,2$ mil. A sua população corresponde a apenas $2 \%$ da brasileira 
DEPARTAMENTO ESTADUAL DE ESTATÍSTICA/ ES 2001; FUNDAÇÃO IBGE 2002; IBGE 2001).

\subsection{Local de Coleta de Dados}

Esta pesquisa foi realizada com dados coletados das Fichas de Notificação/Investigação Gestantes HIV+ e Crianças Expostas (Anexo III), cedidas pela Secretaria Estadual da Saúde do Estado do Espírito Santo - SESA, disponíveis no Banco de Dados do SINAN/SESA/Programa Estadual de DST/Aids, que integra o Sistema de Informação de Gestantes HIV+ e Crianças Expostas - SISGHIV. Esta é uma fonte de dados de informação epidemiológica, que objetiva coletar, transmitir e disseminar dados gerados, rotineiramente, pelo Sistema de Vigilância Epidemiológica nos níveis federal, estadual e municipal, por uma rede informatizada. São dados obtidos de 188 fichas registradas no SINAN, de casos notificados de parturientes HIV positivas no Estado do Espírito Santo, no período de 1999 - 2002.

Para este estudo, a Secretaria cedeu os dados em Excel, o que foi mantido para o estudo, não sendo necessário converter estes dados para outro programa.

A Lei Complementar no 204, publicada no Diário Oficial do Estado do Espírito Santo, em 22 de junho de 2001, instituiu a Região Metropolitana da Grande Vitória - RMGV.

A RMGV compreende o espaço territorial formado pelos Municípios de Cariacica, Fundão, Guarapari, Serra, Viana, Vila Velha e Vitória.

O Quadro 1 mostra que o Estado do Espírito Santo é composto por 78 Municípios, divididos em 4 Macro-Regiões - metropolitana, norte, noroeste e sul - e possui uma população estimada em 3.023 .619 de habitantes. 
Quadro 1 - Estimativa populacional do Estado do Espirito Santo por macroregião e municípios em 2001 Instituto de Brasileiro de Geografia e Estatística, 2001.

\begin{tabular}{|l|r|}
\hline \multicolumn{1}{|c|}{ Municípios } & População Total \\
\hline Macro - Região Metropolitana & \\
Afonso Cláudio & $31.138 \mathrm{hab}$. \\
Alfredo Chaves & $13.502 \mathrm{hab}$. \\
Anchieta & $19.500 \mathrm{hab}$. \\
Aracruz & $67.342 \mathrm{hab}$. \\
Brejetuba & $10.221 \mathrm{hab}$. \\
Cariacica & $330.316 \mathrm{hab}$. \\
Conceição do Castelo & $9.844 \mathrm{hab}$. \\
Domingos Martins & $26.190 \mathrm{hab}$. \\
Fundão & $12.956 \mathrm{hab}$. \\
Guarapari & $83.356 \mathrm{hab}$. \\
Ibiraçu & $10.007 \mathrm{hab}$. \\
Iconha & $12.699 \mathrm{hab}$. \\
Itaguaçu & $15.036 \mathrm{hab}$. \\
Itapemirim & $28.465 \mathrm{hab}$. \\
Itarana & $11.214 \mathrm{hab}$. \\
João Neiva & $15.147 \mathrm{hab}$. \\
Laranja da Terra & $9.965 \mathrm{hab}$. \\
Linhares & $108.234 \mathrm{hab}$. \\
Marataizes & $29.473 \mathrm{hab}$. \\
Marechal Floriano & $12.459 \mathrm{hab}$. \\
Piúma & $13.971 \mathrm{hab}$. \\
Rio Bananal & $16.561 \mathrm{hab}$. \\
Santa Leopoldina & $12.506 \mathrm{hab}$. \\
Santa Maria de Jetibá & $28.915 \mathrm{hab}$. \\
Santa Teresa & $19.502 \mathrm{hab}$. \\
Serra & $323.079 \mathrm{hab}$. \\
Sooretama & $15.576 \mathrm{hab}$. \\
Venda Nova do Imigrante & $15.900 \mathrm{hab}$. \\
Viana & $53.695 \mathrm{hab}$. \\
Vila Velha & $332.240 \mathrm{hab}$. \\
Vitória & $273.634 \mathrm{hab}$. \\
\hline Macro Região Norte & \\
\hline Conceição da Barra & $28.837 \mathrm{hab}$. \\
Jaguaré & $18.271 \mathrm{hab}$. \\
Montanha & $17.245 \mathrm{hab}$. \\
Mucurici & $6.913 \mathrm{hab}$. \\
Pedro Canário & $23.854 \mathrm{hab}$. \\
Pinheiros & $20.225 \mathrm{hab}$. \\
Ponto Belo & $7.573 \mathrm{hab}$. \\
São Mateus & \\
\hline
\end{tabular}




\section{Continuação}

\begin{tabular}{|c|c|}
\hline \multicolumn{2}{|c|}{ Macro Região Noroeste } \\
\hline Águia Branca & 9.502 hab. \\
\hline Água Doce do Norte & 13.151 hab. \\
\hline Alto Rio Novo & 6.952 hab. \\
\hline Baixo Guandu & 26.289 hab. \\
\hline Barra de São Francisco & 37.660 hab. \\
\hline Boa Esperança & 14.503 hab. \\
\hline Colatina & 99.835 hab. \\
\hline Ecoporanga & 20.972 hab. \\
\hline Governador Lindenberg & 9.295 hab. \\
\hline Mantenópolis & 11.474 hab. \\
\hline Marilândia & 9.764 hab. \\
\hline Nova Venécia & 43.768 hab. \\
\hline Pancas & 19.194 hab. \\
\hline São Domingos do Norte & 7.695 hab. \\
\hline São Gabriel da Palha & 25.416 hab. \\
\hline Vila Pavão & 9.249 hab. \\
\hline Vila Valério & 14.263 hab. \\
\hline \multicolumn{2}{|l|}{ Macro-Região Sul } \\
\hline \begin{tabular}{|l} 
Municípios \\
\end{tabular} & População Total \\
\hline Alegre & 32.723 hab. \\
\hline Apiacá & 6.665 hab. \\
\hline Atílio Vivacqua & 7.517 hab. \\
\hline Bom Jesus do Norte & 9.202 hab. \\
\hline Cachoeiro de Itapemirim & 157.973 hab. \\
\hline Castelo & 29.200 hab. \\
\hline Divino de São Lourenço & 4.687 hab. \\
\hline Dores do Rio Preto & 6.038 hab. \\
\hline Guaçuí & 26.807 hab. \\
\hline Ibatiba & 17.589 hab. \\
\hline Ibitirama & 8.276 hab. \\
\hline Irupi & 10.743 hab. \\
\hline Iúna & 26.088 hab. \\
\hline Jerônimo Monteiro & 10.219 hab. \\
\hline Mimoso do Sul & 25.781 hab. \\
\hline Muniz Freire & 18.863 hab. \\
\hline Muqui & 12.425 hab. \\
\hline Presidente Kennedy & 9.892 hab. \\
\hline Rio Novo do Sul & 11.358 ha \\
\hline São José do Calçado & $10.761 \mathrm{ha}$ \\
\hline São Roques do Canaã & 9.347 ha \\
\hline Vargem Alta & $14.075 \mathrm{hab}$ \\
\hline Espirito Santo & 3.023.619 hab \\
\hline
\end{tabular}

Fonte: Instituto Brasileiro de Geografia e Estatística - IBGE, 2001. 


\subsection{Período do Estudo}

A escolha do período de 1999 - 2002 se deu porque, antes de 1999, não era obrigatória a notificação de casos de Aids ao Ministério da Saúde, e esses dados não estavam informatizados. Além disso, foram determinantes três fatos ocorridos no ano de 1999: o primeiro, foi a criação da Câmara Técnica de Aids do Estado do Espírito Santo, na qual passaram a ser representados todos os Serviços de DST/Aids do Estado, bem como as Organizações Não-Governamentais do Estado; o segundo, foi a publicação da Lei Estadual no 123/99, que versa sobre a obrigatoriedade do oferecimento de teste anti-HIV para toda gestante que fizer o exame pré-natal em serviços da rede pública de saúde; e, o terceiro, foi a Portaria da Secretaria de Estado da Saúde no 176-N/99, que obriga a aquisição do material e a realização dos testes anti-HIV, aos laboratórios da rede Municipal, Hospitais Públicos e Conveniados com o Sistema Único de Saúde - SUS, que oferta os Serviços de Pré-Natal.

\subsection{Variáveis de Estudo}

As variáveis selecionadas para este estudo foram:

a. Distribuição de casos, por ano, de diagnóstico;

b. Distribuição de casos, segundo município de notificação;

c. Distribuição de casos, segundo município de residência;

d. Distribuição de casos, segundo anos de estudo da gestante (escolaridade);

e. Distribuição de casos, segundo faixa etária da gestante;

f. Distribuição de casos notificados, segundo categoria de exposição das gestantes $\mathrm{HIV+;}$

g. Gestantes que fizeram pré-natal;

h. Desfecho da gestação;

i. Uso de AZT pela gestante durante o parto;

j. Tempo de uso de AZT oral pelas gestantes; 
k. Aleitamento Materno;

I. Idade gestacional, no início da profilaxia;

m. Casos confirmados de Aids;

n. Distribuição de casos, segundo época do diagnóstico laboratorial do HIV;

o. Gestantes, em uso de antiretrovirais;

p. Gestantes com Aids (casos confirmados) $\times$ gestantes em uso de antiretrovirais;

q. Gestantes com Aids (casos confirmados) x gestantes que fizeram pré-natal;

r. Estado de nascimento do recém-nascido;

s. Tempo transcorrido até o uso do AZT pelo recém-nascido; e,

t. Sorologia do recém-nascido após 24 meses;

As variáveis de estudo são apresentadas em forma de tabelas, com descrição de valores absolutos e respectivos percentuais.

\subsection{Aspectos Éticos}

Quanto a esse aspecto, é importante salientar que o anonimato da população estudada foi garantido, não havendo divulgação do mesmo em respeito à ética, segundo as normas para pesquisa com seres humanos, do Ministério da Saúde, Resolução no 196/96, do Conselho Nacional de Saúde.

\subsection{População de Estudo}

O universo de análise deste estudo foi constituído por mulheres gestantes/parturientes HIV+, a partir dos registros (Fichas de Notificação/Investigação Gestantes HIV+ e Crianças Expostas) constantes do Banco de Dados da Secretária da Saúde - SESA, estimando que existem 188 gestantes soropositivas para o HIV em todo o Estado do Espírito Santo, no período de 1999 2002, conforme Tabela 2. 
Vale ressaltar que os números de casos ignorados, constantes nas tabelas construídas, no decorrer do estudo, correspondem ao não preenchimento ou ao preenchimento incompleto da Ficha por profissionais da área da saúde. 


\section{RESULTADOS}

Os resultados obtidos, a partir de dados coletados dos registros constantes das fichas do SINAN/SESA, do programa estadual de DST/Aids do Espírito Santo, são apresentados, a seguir, na forma de tabelas.

Ao distribuir as gestantes HIV+, registradas na SESA, por ano de diagnóstico, no periodo estudado, verifica-se que 2001 foi o ano de maior incidência de casos registrados (90), o equivalente a $47,9 \%$ do total de casos notificados no período em estudo, não obstante estarem subestimados, em face de problemas no sistema ocorridos nesse ano (Tabela 2).

Tabela 2 - Distribuição das gestantes HIV+, registradas na SESA por ano de diagnóstico, no período de 1999 - 2002. ES, 2004.

\begin{tabular}{ccc}
\hline $\begin{array}{c}\text { Ano de } \\
\text { diagnóstico }\end{array}$ & Número & Percentual \\
\hline 1999 & 20 & 10,6 \\
2000 & 24 & 12,8 \\
$2001^{1}$ & 90 & 47,9 \\
2002 & 54 & 28,7 \\
\hline Total & $\mathbf{1 8 8}$ & $\mathbf{1 0 0 , 0}$ \\
\hline${ }^{1}$ Os dados do ano de 2001 estão sujeitos à revisão, \\
pois , além do atraso entre o diagnóstico e a \\
notificação dos casos pelos municípios no Sistema de \\
Informação de Agravos de Notificação - SINAN, no \\
segundo semestre de 2001, ocorreram vários \\
problemas, devido à nova versão do sistema, e em que \\
os números estão sub-estimados. \\
Fonte: SINAN/SESA-DST/Aids - ES, 2004.
\end{tabular}

Ao distribuir as gestantes HIV+, segundo municípios de notificação, pode-se observar, na Tabela 3, que são os municípios que compõem a Grande Vitória, aqueles que detêm a grande maioria das notificações $(85,6 \%)$, sendo campeão o município de Vitória, capital do Estado, onde se concentram, aproximadamente, $80 \%$ do total de casos notificados. 
Tabela 3 - Distribuição das gestantes HIV+, registradas na SESA, segundo município de notificação, no período de 1999 - 2002. ES, 2004.

\begin{tabular}{lcc}
\hline Município de notificação & Número & Percentual \\
\hline Alegre & 3 & 1,6 \\
Atílio Vivacqua & 2 & 1,1 \\
Cachoeiro de Itapemirim & 2 & 1,1 \\
Colatina & 11 & 5,8 \\
Linhares & 9 & 4,8 \\
Serra & 7 & 3,7 \\
Vila Velha & 4 & 2,1 \\
Vitória & 150 & 79,8 \\
\hline Total & $\mathbf{1 8 8}$ & $\mathbf{1 0 0 , 0}$ \\
\hline
\end{tabular}

Quando se procurou identificar a distribuição das gestantes HIV+, por municípios de residência (Tabela 4), verificou-se que quatro dos municípios que compõem a Região Metropolitana da Grande Vitória: Vitória (20,7\%); Vila Velha $(14,9 \%)$; Serra $(19,7 \%)$; e Cariacica $(16 \%)$, foram aqueles que concentraram o maior número de casos. 
Tabela 4 - Distribuição das gestantes HIV+, registradas na SESA, segundo município de residência, no período de 1999 - 2002. ES, 2004.

\begin{tabular}{lrr}
\hline Município de residência & Número & Percentual \\
\hline Alegre & 3 & 1,6 \\
Anchieta & 1 & 0,5 \\
Aracruz & 4 & 2,1 \\
Atílio Vivacqua & 2 & 1,1 \\
Baixo Guandu & 2 & 1,1 \\
Barra de São Francisco & 4 & 2,1 \\
Cachoeiro de Itapemirim & 2 & 1,1 \\
Cariacica & 30 & 16,0 \\
Colatina & 5 & 2,7 \\
Domingos Martins & 2 & 1,1 \\
Ecoporanga & 1 & 0,5 \\
Guarapari & 4 & 2,1 \\
Linhares & 8 & 4,3 \\
Marataizes & 2 & 1,1 \\
Montanha & 1 & 0,5 \\
Nova Venécia & 1 & 0,5 \\
Santa Maria de Jetibá & 1 & 0,5 \\
São Gabriel da Palha & 2 & 1,1 \\
Serra & 37 & 19,7 \\
Sooretama & 2 & 1,1 \\
Viana & 4 & 2,1 \\
Vila Velha & 28 & 14,9 \\
Vitória & 39 & 20,7 \\
Outros Municípios & & 1,6 \\
\hline Total & & \\
\hline Fonte: SINAN/SESA-DST/Aids-ES, & \\
\hline
\end{tabular}

Fonte: SINAN/SESA-DST/Aids-ES, 2004.

Procurando obter uma visão mais clara da distribuição das gestantes HIV+, no sentido de verificar a dinâmica seguida por elas, no que diz respeito a municípios de residência e locais de notificação, foi construída a Tabela 5.

Observa-se que 0 maior número de casos encontra-se na Região Metropolitana da Grande Vitória, e que, apenas 39, das 150 notificações, correspondem a gestantes residentes em Vitória. Das 37 mulheres, que residem na Serra, $30(81,1 \%)$ foram notificadas em Vitória; das 28 mulheres residentes em Vila 
Velha, $24(85,7 \%)$ foram notificadas em Vitória e das 30 mulheres, que residem em Cariacica, $30(100 \%)$ foram notificadas em Vitória. Isso quer dizer que Vitória concentra a maior parte das notificações de municípios da Região Metropolitana, independentemente dos locais de residência das gestantes do presente estudo. 
Tabela 5 - Distribuição das gestantes HIV+, registradas na SESA, segundo município de residência e de notificação, no período de 1999 - 2002. ES, 2004.

\begin{tabular}{|c|c|c|c|c|c|c|c|c|c|c|c|c|c|c|c|c|c|}
\hline \multirow{3}{*}{$\begin{array}{l}\text { Muniápio de } \\
\text { residência }\end{array}$} & \multirow{2}{*}{\multicolumn{2}{|c|}{ Alegre }} & \multirow{2}{*}{\multicolumn{2}{|c|}{$\begin{array}{c}\text { Atilio } \\
\text { Vivacqua }\end{array}$}} & \multicolumn{6}{|c|}{ Municipío de Notificação } & \multirow{2}{*}{\multicolumn{2}{|c|}{ Serra }} & \multirow{2}{*}{\multicolumn{2}{|c|}{$\begin{array}{l}\text { Vila } \\
\text { Velha }\end{array}$}} & \multirow{2}{*}{\multicolumn{2}{|c|}{ Vitória }} & \multirow{3}{*}{$\begin{array}{c}\text { Total } \\
\%\end{array}$} \\
\hline & & & & & \multicolumn{2}{|c|}{$\begin{array}{l}\text { Cachoeiro de } \\
\text { Itapemirim }\end{array}$} & \multicolumn{2}{|c|}{ Colatina } & \multicolumn{2}{|c|}{ Linhares } & & & & & & & \\
\hline & No & $\%$ & No & $\%$ & No & $\%$ & № & $\%$ & No & $\%$ & No & $\%$ & $\begin{array}{c}N \\
0\end{array}$ & $\%$ & No & $\%$ & \\
\hline Alegre & 3 & 100,0 & - & - & - & - & - & - & - & - & - & - & - & - & - & - & 100,0 \\
\hline Anchieta & - & - & - & - & - & - & - & - & - & - & - & - & - & - & 1 & 100,0 & 100,0 \\
\hline Aractuz & - & - & - & - & - & - & - & - & - & - & - & - & - & - & 4 & 100,0 & 100,0 \\
\hline Atilio Vivacqua & - & - & 2 & 100,0 & - & - & - & - & - & - & - & - & - & - & - & - & 100,0 \\
\hline Baixo Guandu & - & - & - & - & - & - & 2 & 100,0 & - & - & - & - & - & - & - & - & 100,0 \\
\hline Barra de São Francisco & - & - & - & - & - & - & 2 & 50,0 & - & - & - & - & - & - & - & - & 100,0 \\
\hline Cachoeiro de Itapemirim & - & - & - & - & 2 & 100,0 & - & - & - & - & - & - & - & - & - & - & 100,0 \\
\hline Cariacica & - & - & - & - & - & - & - & - & - & - & - & - & - & - & 30 & 100,0 & 100,0 \\
\hline Colatina & - & - & - & - & - & - & 4 & 80,0 & - & - & - & - & - & - & - & - & 100,0 \\
\hline Domingos Martins & - & - & - & - & - & - & - & - & - & - & - & - & - & - & 2 & 100,0 & 100,0 \\
\hline Ecoporanga & - & - & - & - & - & - & - & - & - & - & - & - & - & - & 1 & 100,0 & 100,0 \\
\hline Guarapari & - & - & - & - & - & - & - & - & - & - & - & - & - & - & 4 & 100,0 & 100,0 \\
\hline Uinhares & - & - & - & - & - & - & - & - & 7 & 87,5 & - & - & - & - & 1 & 12,5 & 100,0 \\
\hline Marataizes & - & - & - & - & - & - & - & - & - & - & - & - & - & - & 2 & 100,0 & 100,0 \\
\hline Montanha & - & - & - & - & - & - & - & - & - & - & - & - & - & - & 1 & 100,0 & 100,0 \\
\hline Nova Venécia & - & - & - & - & - & - & 1 & 100,0 & - & - & - & - & - & - & - & - & 100,0 \\
\hline Santa Maria de Jetibá & - & - & - & - & - & - & - & - & - & - & - & - & - & - & 1 & 100,0 & 100,0 \\
\hline São Gabriel da Palha & - & - & - & - & - & - & 2 & 100,0 & - & - & - & - & - & - & - & - & 100,0 \\
\hline Serra & - & - & - & - & - & - & - & - & - & - & 7 & 18,9 & - & - & 30 & 81,1 & 100,0 \\
\hline Sooretama & - & - & - & - & - & - & - & - & 2 & 100,0 & - & - & - & - & - & - & 100,0 \\
\hline Viana & - & - & - & - & - & - & - & - & - & - & - & - & - & - & 4 & 100,0 & 100,0 \\
\hline Vila Velha & - & - & - & - & - & - & - & - & - & - & - & - & 4 & $\begin{array}{r}14, \\
3\end{array}$ & 24 & 85,7 & 100,0 \\
\hline Vitória & - & - & - & - & - & - & - & - & - & - & - & - & - & - & 39 & 100,0 & 100,0 \\
\hline Outros Municípios & - & - & - & - & - & - & - & - & - & - & - & - & - & - & 3 & 100,0 & 100,0 \\
\hline Total & 3 & 1,6 & 2 & 1,1 & 2 & 1,1 & 11 & 5,8 & 9 & 4,8 & 7 & 3,7 & 4 & 2,1 & 150 & 79,8 & 100,0 \\
\hline
\end{tabular}

onte: SINAN/SESA-DST/Aids- ES, 2004.

O conhecimento da escolaridade das gestantes HIV+, registradas na SESA, no período de estudo, ficou prejudicado, dado que se trata de ítem não preenchido em 77 (41\%) das fichas. 
Tabela 6 - Distribuição das gestantes HIV+, registradas na SESA, segundo escolaridade, no periodo de 1999 - 2002. ES, 2004.

\begin{tabular}{lrr}
\hline Anos de estudo & Número & Percentual \\
\hline Nenhum & 10 & 5,3 \\
De 1 a 3 & 25 & 13,3 \\
4 a 7 & 41 & 21,8 \\
De 8 a 11 & 30 & 15,9 \\
De 12 em diante & 5 & 2,7 \\
Ignorado & 77 & 41,0 \\
\hline Total & $\mathbf{1 8 8}$ & $\mathbf{1 0 0 , 0}$ \\
\hline
\end{tabular}

Fonte: SINAN/SESA-DST/Aids- ES, 2004.

Constata-se, com base nos registros (de $59 \%$ das gestantes do estudo), que a proporção de mulheres com até 7 anos de estudo corresponde, praticamente, àquela da categoria de "ignorado", e o percentual daquelas com nenhum ano de estudo é bastante baixo, em número de 10 casos (5,3\%).

No que diz respeito à idade dessas gestantes, que compõem a população de estudo, a distribuição, por faixas etárias, é apresentada na Tabela 7.

Tabela 7 - Distribuição das gestantes HIV+, registradas na SESA, segundo faixa etária, no período de 1999 - 2002.ES, 2004.

\begin{tabular}{lrc}
\hline Faixa etária (anos) & Número & Percentual \\
\hline 13 a 14 & 4 & 2,1 \\
15 a 19 & 28 & 14,9 \\
20 a 24 & 85 & 45,2 \\
25 a 29 & 38 & 20,2 \\
30 a 34 & 17 & 9,0 \\
35 a 39 & 13 & 7,0 \\
40 a 43 & 3 & 1,6 \\
\hline Total & $\mathbf{1 8 8}$ & $\mathbf{1 0 0 , 0}$ \\
\hline
\end{tabular}

Fonte: SINAN/SESA-DST/Aids - ES, 2004.

Observa-se que a faixa etária em que se concentra maior número de gestantes da população de estudo é a de 20-24 anos, com 85 casos (45,2\%), seguida de 25-29 anos, 38 casos (20,2\%). Entretanto, há de ser chamada atenção para a faixa de 13-14 anos, por ser o intervalo menor que nas demais, pelo que 
poderia considerar-se que, proporcionalmente, essa freqüência poderia ser ainda maior, ou que é grande, em relação às demais.

Para se ter uma idéia mais clara do nível de escolaridade das mulheres do estudo, segundo faixa etária, apresenta-se a Tabela 8, construída a partir dos dados registrados, valendo a observação da existência de omissão do dado em $41 \%$ das fichas, avolumando a categoria de "ignorado".

Tabela 8 - Distribuição das gestantes HIV+, registradas na SESA, segundo faixa etária e escolaridade, no período de 1999 - 2002.ES, 2004.

\begin{tabular}{|c|c|c|c|c|c|c|c|c|c|c|c|c|c|}
\hline \multirow{3}{*}{$\begin{array}{l}\text { Faixa } \\
\text { etária } \\
\text { (anos) }\end{array}$} & \multicolumn{12}{|c|}{ Escolaridade } & \multirow{3}{*}{$\begin{array}{c}\text { Total } \\
\%\end{array}$} \\
\hline & \multicolumn{2}{|c|}{ Nenhuma } & \multicolumn{2}{|c|}{1 a 3} & \multicolumn{2}{|c|}{4 a 7} & \multicolumn{2}{|c|}{8 a 11} & \multicolumn{2}{|c|}{12 e mais } & \multicolumn{2}{|c|}{ Ignorado } & \\
\hline & No & $\%$ & No & $\%$ & No & $\%$ & No & $\%$ & No & $\%$ & No & $\%$ & \\
\hline 13 a 14 & 1 & 25,0 & 3 & 75,0 & - & - & - & - & - & - & - & - & 100,0 \\
\hline 15 a 19 & 3 & 10,5 & 4 & 15,5 & 7 & 24,5 & 6 & 21,5 & - & - & 8 & 28,0 & 100,0 \\
\hline 20 a 24 & 1 & 1,2 & 3 & 3,6 & 17 & 20,4 & 16 & 19,2 & - & - & 48 & 55,6 & 100,0 \\
\hline 25 a 29 & 2 & 5,2 & 8 & 21,1 & 9 & 23,7 & 6 & 15,8 & 3 & 7,9 & 10 & 26,3 & 100,0 \\
\hline 30 a 34 & 3 & 17,6 & 3 & 17,6 & 4 & 23,5 & 1 & 5,9 & 2 & 11,80 & 4 & 23,5 & 100,0 \\
\hline 35 a 39 & - & - & 3 & 23,1 & 4 & 30,8 & - & - & - & - & 6 & 46,1 & 100,0 \\
\hline 40 a 43 & - & - & 1 & 33,3 & - & - & 1 & 33, & - & - & 1 & 33,3 & 100,0 \\
\hline Total & 10 & 5,3 & 25 & 13,3 & 41 & 21,8 & 30 & 15,9 & 5 & 2,7 & 77 & 41,0 & 100,0 \\
\hline
\end{tabular}

Fonte: SINAN/SESA-DST/Aids- ES, 2004.

No conjunto das gestantes, $13,3 \%$ delas são portadoras de até três anos de estudo, notando-se, em uma leitura horizontal da tabela acima, que o número de mulheres com menor escolaridade é bastante acentuado nas idades de 13-14 anos (100\%), seguidas da faixa de 30 a 34 anos (35,2\%), de 40 a 43 anos $(33,3 \%)$ e de 15 a 19 anos (26\%); por outro lado, o grupo com maior escolaridade (12 anos e mais de estudo), correspondendo a $2,7 \%$, localizou-se em apenas duas faixas etárias: 30 a 34 anos e 25 a 29 anos.

No que se refere a formas de transmissão do HIV a essas mulheres, a Tabela 9 apresenta as categorias de exposição a que elas referiram terem se submetido. 
Tabela 9 - Distribuição das gestantes HIV+, registradas na SESA, segundo categoria de exposição, no período de 1999 - 2002. ES, 2004.

\begin{tabular}{lrr}
\hline Categoria de exposição & Número & Percentual \\
\hline Sexual & 108 & $\mathbf{5 7 , 5}$ \\
UDI & 11 & 5,9 \\
Transfusão & 1 & 0,5 \\
Acidente material biológico & 1 & 0,5 \\
Ignorado & 67 & 35,6 \\
\hline Total & $\mathbf{1 8 8}$ & $\mathbf{1 0 0 , 0}$ \\
\hline
\end{tabular}

Fonte: SINAN/SESA-DST/Aids- ES, 2004.

Observa-se que 108 casos (quase 60\%) das gestantes contaminadas 0 foram via sexual, seguida de UDI - 11 casos $(5,9 \%)$. Novamente, chama atenção o número de "ignorado", 67 casos $(35,6 \%)$, revelando problemas, ou de preenchimento, ou dificuldade na obtenção desse dado, junto a mulheres nessas condições, por envolver questões da intimidade, entre outras. De qualquer forma, desconhecer a forma de transmissão em $35,6 \%$ de uma população de estudo é um problema que requer ser estudado, com maior cuidado.

Ao procurar verificar se essas gestantes HIV+ haviam se submetido ao acompanhamento pré-natal, apontado como uma condição importante para detecção precoce de casos, constatou-se que, praticamente, apenas a metade do grupo o havia feito, de acordo com os registros, conforme mostra a Tabela 10.

Tabela 10 - Distribuição das gestantes HIV+, registradas na SESA, segundo realização de pré-natal, no período de 1999 - 2002. ES, 2004.

\begin{tabular}{lcc}
\hline Pré-natal & Número & Percentual \\
\hline Sim & 105 & 55,9 \\
Não & 26 & 13,8 \\
Ignorado & 57 & 30,3 \\
\hline Total & $\mathbf{1 8 8}$ & $\mathbf{1 0 0 , 0}$ \\
\hline
\end{tabular}

Fonte: SINAN/SESA-DST/Aids- ES, 2004.

Na Tabela 10, pode-se observar que apenas $105(55,9 \%)$ das gestantes fizeram o pré-natal, com a ressalva da grande proporção de "ignorados", que 
correspondeu a $30 \%$. Ao cotejar o número de gestantes, cujos registros atestam terem realizado o pré-natal, e os dados constantes da Tabela 11, sobre a época do diagnóstico laboratorial, que apontam o período de pré-natal, em maior freqüência, é de se supor que o número de gestantes que fizeram o pré-natal seja maior do que o registrado.

Tabela 11 - Distribuição das gestantes HIV+, registradas na SESA, segundo época do diagnóstico laboratorial do HIV, no período de 1999 - 2002. ES, 2004.

\begin{tabular}{lrc}
\hline Diagnóstico & Número & Percentual \\
\hline Antes do pré-natal & 20 & 10,6 \\
Durante o pré-natal & 137 & 72,9 \\
Durante ou após o parto & 7 & 3,7 \\
Ignorado & 24 & 12,8 \\
\hline Total & $\mathbf{1 8 8}$ & $\mathbf{1 0 0 , 0}$ \\
\hline
\end{tabular}

Fonte: SINAN/SESA-DST/Aids- ES, 2004.

Na tabela 11, nota-se maior número de casos diagnosticados durante a realização do pré-natal 137 (72,9\%), seguido de $20(10,6 \%)$ que foram diagnosticados antes do pré-natal e $7(3,7 \%)$, durante ou após o parto; em 24 casos (12\%), ignora-se a época do diagnóstico. Esses dados vêm confirmar que o pré-natal constitui um momento importante para detectar casos de HIV+.

Prosseguindo no trabalho de obter um perfil dessa população de estudo, são apresentados na Tabela 12 os resultados referentes à idade gestacional em que essas mulheres iniciaram a profilaxia. 
Tabela 12 - Distribuição das gestantes HIV+, registradas na SESA, segundo idade gestacional no início da profilaxia, no periodo de 1999 - 2002. ES, 2004.

\begin{tabular}{|c|c|c|}
\hline $\begin{array}{l}\text { Semana } \\
\text { gestação }\end{array}$ & Número & Percentual \\
\hline 10 & 1 & 0,5 \\
\hline 12 & 11 & 5,9 \\
\hline 13 & 1 & 0,5 \\
\hline 14 & 13 & 6,9 \\
\hline 15 & 1 & 0,5 \\
\hline 16 & 20 & 10,6 \\
\hline 17 & 1 & 0,5 \\
\hline 18 & 2 & 1,1 \\
\hline 19 & 3 & 1,6 \\
\hline 20 & 6 & 3,2 \\
\hline 21 & 1 & 0,5 \\
\hline 22 & 2 & 1,1 \\
\hline 23 & 1 & 0,5 \\
\hline 24 & 7 & 3,7 \\
\hline 25 & 2 & 1,1 \\
\hline 26 & 4 & 2,1 \\
\hline 27 & 1 & 0,5 \\
\hline 28 & 4 & 2,1 \\
\hline 30 & 2 & 1,1 \\
\hline 32 & 3 & 1,6 \\
\hline 33 & 1 & 0,5 \\
\hline 34 & 2 & 1,1 \\
\hline 35 & 2 & 1,1 \\
\hline 36 & 1 & 0,5 \\
\hline 37 & 1 & 0,5 \\
\hline 40 & 1 & 0,5 \\
\hline Ignorado & 94 & 50,0 \\
\hline Total & 188 & 100,0 \\
\hline
\end{tabular}

Observa-se pela tabela, acima, que a idade gestacional no início da profilaxia com $A Z T$, ocorreu, em maior número, na $16^{\mathrm{a}}$ semana $(10,6 \%)$, e que, aproximadamente, $25 \%$ tiveram início entre a $10^{\mathrm{a}}$ e a $16^{\mathrm{a}}$ semana gestacional; observa-se, também, que em metade das fichas das gestantes registradas na SESA, o campo de idade gestacional no início da profilaxia não havia sido preenchido. 
Procurou-se verificar, entre essas mulheres com HIV+, quantas delas estariam usando antiretrovirais durante o período de estudo. Os resultados são apresentados na Tabela 13.

Tabela 13 - Distribuição das gestantes HIV+, registradas na SESA, segundo uso de antiretrovirais, no período de 1999 - 2002. ES, 2004.

\begin{tabular}{lrr}
\hline $\begin{array}{l}\text { Uso de } \\
\text { anti-retroviral }\end{array}$ & Número & Percentual \\
\hline Sim & 62 & 33,0 \\
Não & 71 & 37,8 \\
Ignorado & 55 & 29,3 \\
\hline Total & $\mathbf{1 8 8}$ & $\mathbf{1 0 0 , 0}$ \\
\hline
\end{tabular}

Fonte: SINAN / SESA-DST/Aids - ES, 2004.

Da Tabela 13, destaca-se que apenas $1 / 3$ das gestantes usaram antiretrovirais, cabendo a observação sobre o alto percentual de ignorados, 55 casos $(29,3 \%)$, quase o correspondente à proporção daquelas que usaram antiretrovirais.

Contando apenas com dados de $49 \%$ da população de estudo ( $51 \%$ de ignorados), foi possivel constatar que $20,7 \%$ das gestantes usaram AZT oral durante 13 a 26 semanas e 11,2\%, durante uma a 12 semanas, no período considerado, enquanto $9,6 \%$ delas não usaram (Tabela 14).

Tabela 14 - Distribuição das gestantes HIV+, registradas na SESA, segundo tempo de uso de AZT oral, no período de 1999 - 2002.ES, 2004.

\begin{tabular}{lcc}
\hline Tempo de uso & Número & Percentual \\
\hline Não usou & 18 & 9,6 \\
1 a 12 semanas & 21 & 11,2 \\
13 a 26 semanas & 39 & 20,7 \\
27 a 40 semanas & 14 & 7,4 \\
Ignorado & 96 & 51,1 \\
\hline Total & $\mathbf{1 8 8}$ & $\mathbf{1 0 0 , 0}$ \\
\hline Fonte: SINAN/SESA-DST/Aids- ES, 2004.
\end{tabular}


Foi importante procurar identificar quantas dessas gestantes $\mathrm{HIV+}$ desenvolveram Aids, no período de estudo. Na Tabela 15, é apresentada a distribuição das gestantes HIV+, segundo casos confirmados de Aids, no período de 1999 a 2002.

Tabela 15 - Distribuição das gestantes HIV+, registradas na SESA, segundo casos confirmados de Aids, no período de 1999 - 2002. ES, 2004.

\begin{tabular}{lrr}
\hline $\begin{array}{l}\text { Confirmação } \\
\text { de Aids }\end{array}$ & Número & Percentual \\
\hline Sim & 70 & 37,2 \\
Não & 56 & 29,8 \\
Ignorado & 62 & 33,0 \\
\hline Total & $\mathbf{1 8 8}$ & $\mathbf{1 0 0 , 0}$ \\
\hline
\end{tabular}

Fonte: SINAN/SESA-DST/Aids- ES, 2004.

Observa-se que mais de um terço das gestantes contaminadas pelo vírus do HIV, tiveram confirmação de Aids, no período de estudo, ao lado de quase o equivalente de "ignorados" (33,0\%), enquanto $29,8 \%$ não evoluíram para a doença. Fica a dúvida sobre categoria que seria mais contemplada pelas gestantes, que estão categorizadas em " ignorados".

Avançando um pouco mais, investigou-se se os casos confirmados de Aids correspondiam a mulheres que haviam feito uso de anti-retrovirais, durante o período de estudo. Os resultados, a esse respeito, são apresentados na Tabela 16.

Tabela 16 - Distribuição das gestantes HIV+, registradas na SESA, segundo confirmação de Aids e uso de anti-retroviral, no período de 1999 2002. ES, 2004.

\begin{tabular}{|c|c|c|c|c|c|c|c|}
\hline \multirow{3}{*}{$\begin{array}{l}\text { Mulher } \\
\text { com Aids }\end{array}$} & \multicolumn{6}{|c|}{ Uso de anti-retroviral } & \multirow{3}{*}{$\begin{array}{c}\text { Total } \\
\%\end{array}$} \\
\hline & \multicolumn{2}{|c|}{ Sim } & \multicolumn{2}{|c|}{ Não } & \multicolumn{2}{|c|}{ Ignorado } & \\
\hline & No & $\%$ & No & $\%$ & No & $\%$ & \\
\hline$\overline{\text { Sim }}$ & 44 & 62,9 & 22 & 31,4 & 4 & 5,7 & 100,0 \\
\hline Não & 12 & 21,4 & 40 & 71,4 & 4 & 7,2 & 100,0 \\
\hline Ignorado & 6 & 9,7 & 9 & 14,5 & 47 & 75,8 & 100,0 \\
\hline Total & 62 & 100,0 & 71 & 100,0 & 55 & 100,0 & 100,0 \\
\hline
\end{tabular}

Fonte: SINAN/SESA-DST/Aids - ES, 2004. 
Constatou-se que, das 70 gestantes com Aids, somente 44 (62,9\%) haviam feito uso de anti-retroviral, enquanto $12(21,4 \%)$ não o fizeram. Observa-se, ainda, que, das 62 gestantes, sobre cuja condição se ignorava, em 47 casos (75,8\%) delas, também, ignorava-se se haviam feito, ou não, uso de anti-retroviral.

Outro aspecto investigado foi a relação entre confirmação de Aids e realização do pré-natal, nesse periodo (Tabela 17).

Tabela 17 - Distribuição das gestantes com confirmação de Aids, registradas na SESA, segundo gestantes que fizeram pré-natal, no período de 1999 2002.ES, 2004.

\begin{tabular}{lccccccc}
\hline \multirow{2}{*}{$\begin{array}{l}\text { Mulher } \\
\text { com Aids }\end{array}$} & \multicolumn{2}{c}{ Sim } & \multicolumn{2}{c}{ Pré-natal } & \multicolumn{2}{c}{ Não } & \multicolumn{2}{c}{ Ignorado } & Total \\
& No & $\%$ & No & $\%$ & No & $\%$ & $\%$ \\
\hline Sim & 50 & 71,4 & 9 & 12,9 & 11 & 15,7 & 100,0 \\
Não & 36 & 64,3 & 8 & 14,3 & 12 & 21,4 & 100,0 \\
Ignorado & 19 & 30,7 & 9 & 14,5 & 34 & 54,8 & 100,0 \\
\hline Total & $\mathbf{1 0 5}$ & $\mathbf{1 0 0 , 0}$ & $\mathbf{2 6}$ & $\mathbf{1 0 0 , 0}$ & $\mathbf{5 7}$ & $\mathbf{1 0 0 , 0}$ & $\mathbf{1 0 0 , 0}$ \\
\hline
\end{tabular}

Fonte: SINAN/SESA-DST/Aids- ES, 2004.

Pode-se observar, na tabela 17, que das 70 gestantes com confirmação de Aids, $50(71,4 \%)$ delas haviam feito o pré-natal. Nota-se que, das 62 gestantes em que se ignorava a sua condição, em 34 (54,8\%) delas, também, ignorava-se sobre a realização do pré-natal.

Em seguida, buscou-se conhecer qual teria sido o desfecho da gestação dessas mulheres HIV+, no período de estudo, obtendo-se os resultados que são apresentados na Tabela 18.

Tabela 18 - Distribuição das gestantes HIV+, registradas na SESA, segundo tipo de desfecho da gestação, no período de 1999 - 2002. ES, 2004.

\begin{tabular}{lrc}
\hline Desfecho & Número & Percentual \\
\hline Normal & 79 & 42,0 \\
Cesáreo & 82 & 43,6 \\
Aborto & 4 & 2,1 \\
Ignorado & 23 & 12,3 \\
\hline Total & $\mathbf{1 8 8}$ & $\mathbf{1 0 0 , 0}$ \\
\hline Fonte: SINAN/SESA-DST/Aids- ES & $\mathbf{2 0 0 4}$
\end{tabular}


Na tabela 18, percebe-se que não houve predominância de um tipo de parto (normal/cesáreo), tendo havido 4 abortos. Novamente, não se sabe qual foi o desfecho de $12,3 \%$ das gestações dessas mulheres.

Considerando-se que a profilaxia inclui o uso de AZT durante o parto, em mulheres HIV+, procurou-se investigar se esse procedimento teria sido seguido, por ocasião do parto dessas mulheres (Tabela 19).

Tabela 19 - Distribuição das gestantes HIV+, registradas na SESA, segundo uso de AZT durante parto, no período de 1999 - 2002.ES, 2004*.

\begin{tabular}{lcc}
\hline Uso de AZT & Número* & Percentual \\
\hline Sim & 116 & 63,0 \\
Não & 43 & 23,4 \\
Ignorado & 25 & 13,6 \\
\hline Total & $\mathbf{1 8 4}$ & $\mathbf{1 0 0 , 0}$ \\
\hline * Excluídos 4 casos por aborto. & \\
Fonte: SINAN/SESA-DST/Aids- ES, 2004.
\end{tabular}

Os resultados obtidos revelam que, do total de 184 partos de mulheres HIV +, 43 casos (23,4\%), aproximadamente, $1 / 4$ das gestantes, não receberam AZT durante o parto, quando a expectativa era de que todas elas tivessem recebido.

Diante desse resultado, procurou-se verificar se o uso, ou não, do AZT durante o parto teria alguma relação com o tipo de desfecho da gestação. Os resultados são apresentados na Tabela 20.

Tabela 20 - Distribuição das gestantes HIV+, registradas na SESA, segundo tipo de desfecho da gestação e uso de AZT durante o parto, no período de 1999 - 2002. ES, 2004*

\begin{tabular}{lccccccc}
\hline \multirow{2}{*}{ Desfecho** } & \multicolumn{7}{c}{ Uso de AZT durante o parto** } \\
& No & $\%$ & No & $\%$ & Namo & $\%$ & $\%$ \\
\hline Normal & 41 & 51,9 & 33 & 41,8 & 5 & 6,3 & 100,0 \\
Cesáreo & 69 & 84,1 & 8 & 9,8 & 5 & 6,1 & 100,0 \\
Ignorado & 6 & 26,1 & 2 & $\mathbf{8 , 7}$ & 15 & 65,2 & 100,0 \\
\hline Total & $\mathbf{1 1 6}$ & $\mathbf{1 0 0 , 0}$ & $\mathbf{4 3}$ & $\mathbf{1 0 0 , 0}$ & $\mathbf{2 5}$ & $\mathbf{1 0 0 , 0}$ & $\mathbf{1 0 0 , 0}$ \\
\hline
\end{tabular}

* Excluídos 4 casos por aborto.

Fonte: SINAN/SESA-DST/Aids- ES, 2004. 
Das gestantes HIV+, que tiveram parto normal, somente $41(51,9 \%)$ tomaram AZT durante o parto, enquanto este percentual, entre as mulheres que tiveram parto cesáreo, foi de $84,1 \%$. Dentre os desfechos ignorados, verifica-se que $26,1 \%$ de mulheres nessa categoria receberam AZT durante o parto.

$\mathrm{Na}$ Tabela 21, é apresentada a distribuição das gestantes do estudo, segundo prática do aleitamento materno, visto que constitui um componente importante na transmissão vertical do HIV.

Tabela 21 - Distribuição das gestantes HIV+, registradas na SESA, segundo aleitamento materno, no período de 1999 - 2002. ES, 2004.

\begin{tabular}{lcc}
\hline $\begin{array}{l}\text { Aleitamento } \\
\text { materno }\end{array}$ & Número & Percentual \\
\hline Sim & 17 & 9,4 \\
Não & 140 & 77,3 \\
Ignorado* & 24 & 13,3 \\
\hline Total & $\mathbf{1 8 1}$ & $\mathbf{1 0 0 , 0}$ \\
\hline
\end{tabular}

*Excluídos 4 abortos e 3 natimortos

Fonte: SINAN/SESA-DST/Aids- ES, 2004.

Os resultados encontrados revelam que 140 (77,3\%) recém-nascidos não receberam aleitamento materno, porém constitui motivo de preocupação a proporção daqueles que foram amamentados pela mãe soropositiva $(9,4 \%)$ e daqueles, sobre cujo tipo de aleitamento se desconhece $(13,3 \%)$.

Anterior à questão acima, interessou conhecer o resultado da gestação dessas mulheres HIV+, que constituíram a população do presente estudo. Assim, na Tabela 22, é apresentada a distribuição dessas mulheres HIV+, segundo produto do desfecho da gestação. 
Tabela 22 - Distribuição das gestantes HIV+, registradas na SESA, segundo produto do desfecho da gestação, no período de 1999 - 2002. ES, 2004.

\begin{tabular}{lcc}
\hline Produto da gestação & Número & Percentual \\
\hline Nascido Vivo & 166 & 88,3 \\
Natimorto & 3 & 1,6 \\
Aborto & 4 & 2,1 \\
Ignorado & 15 & $\mathbf{8 , 0}$ \\
\hline Total & $\mathbf{1 8 8}$ & $\mathbf{1 0 0 , 0}$ \\
\hline
\end{tabular}

Fonte: SINAN/SESA-DST/Aids- ES 2004.

Pelos dados acima, observa-se que $166(88,3 \%)$ das gestações resultaram em nascidos vivos, $04(2,1 \%)$ em aborto e 03 dos produtos, natimortos. Em 15 casos $(8,0 \%)$, ignora-se qual foi o resultado gestacional.

Diante de 166 nascidos vivos, no período de estudo, restava saber se os mesmos haviam recebido o AZT, conforme o preconizado, assim como dentro de que prazos de tempo, após o seu nascimento. Na Tabela 23, é possivel observar os resultados encontrados a esse respeito.

Tabela 23 - Distribuição das gestantes HIV+, registradas na SESA, segundo tempo transcorrido até o uso do AZT pelo recém-nascido, no período de 1999 - 2002. ES, 2004*.

\begin{tabular}{lcc}
\hline Tempo transcorrido & Número* & Percentual \\
\hline Nas primeiras 24 horas & 141 & 77,9 \\
Após 24 horas do nascimento & 6 & 3,3 \\
Não realizado & 2 & 1,1 \\
Ignorado & 32 & 17,7 \\
\hline Total & $\mathbf{1 8 1}$ & $\mathbf{1 0 0 , 0}$ \\
\hline
\end{tabular}

* Exduídos 4 casos por aborto e 3 casos natimortos. Fonte: SINAN/SESA-DST/Aids- ES, 2004.

Na tabela 23, nota-se que 141 (77,9\%) dos recém-nascidos receberam AZT nas primeiras 24 horas e 06 (3,3\%), após 24 horas. Chama atenção, ainda, o fato de não ter sido realizado o procedimento, acima descrito, em 2 recém-nascidos $(1,1 \%)$ e de nada constar nos registros sobre o motivo dessa não realização. Foi expressiva a proporção de casos ignorados (32 - 17,7\%). 
Acompanhando a seqüência de procedimentos realizados com a criança, filho/a dessas mulheres $\mathrm{HIV}+$, segundo as recomendações preconizadas por organismos de saúde, a Tabela 24 refere-se aos resultados encontrados quanto à sorologia da criança, após 24 meses de nascimento.

Tabela 24 - Distribuição das mulheres HIV+, registradas na SESA, segundo sorologia da criança, após 24 meses, no período de 1999 - 2002. ES, 2004*.

\begin{tabular}{lcc}
\hline $\begin{array}{l}\text { Sorologia da criança, } \\
\text { após } \mathbf{2 4} \text { meses }\end{array}$ & Número* & Percentual \\
\hline Positivo & 7 & 3,9 \\
Negativo & 64 & 35,4 \\
Não realizado & 3 & 1,6 \\
Ignorado & 107 & 59,1 \\
\hline Total & $\mathbf{1 8 1}$ & $\mathbf{1 0 0 , 0}$ \\
* Exduídos 4 casos por aborto e 3 casos natimortos. \\
Fonte: SINAN/SESA-DST/Aids- ES, 2004.
\end{tabular}

Observa-se, pelos dados apresentados, a existência de registro de apenas 74 (41,9\%) crianças, filhos das mulheres incluidas no estudo, em prejuízo de análises a respeito dos resultados. Reconhecida essa limitação, em face do desconhecimento da situação de 107 crianças $(59,1 \%)$, é possivel verificar que, entre os 74 casos registrados, a maioria (64) das crianças apresentou sorologia negativa, aos 24 meses de idade, enquanto 7 tiveram diagnóstico positivo para HIV, além do registro de que a sorologia não foi realizada em três crianças, sem esclarecimento dos motivos de sua não realização. Esses resultados podem estar revelando a eficácia das medidas profiláticas que foram tomadas em relação à gestante HIV+ durante o pré-natal, durante o parto e com o recém-nascido. 


\section{DISCUSSÃO}

A pesquisa realizada foi direcionada para a obtenção do perfil epidemiológico da transmissão vertical do HIV, no Estado do Espírito Santo, no período de 19992002. Nesse período, segundo os registros oficiais, havia 188 gestantes soropositivas para o HIV, sendo que o ano de 2001 foi o de maior incidência, apresentando 90 casos (47,9\%), registrados na SESA - DST/Aids-ES (Tabela 2).

O problema da Aids, no Espírito Santo, concentra-se nos municípios da Região da Grande Vitória, sendo o município de Vitória, capital do Estado, aquele de maior concentração, detendo até $70 \%$ dos casos de residência e $90 \%$ de notificação. Portanto, confirma-se, como em outros estudos, a maior freqüência de casos nos grandes centros urbanos, ainda que, municípios localizados fora do âmbito da Região da Grande Vitória, como Colatina e Linhares, constituissem locais de residência de quase $8 \%$ de gestantes $\mathrm{HIV}_{+}$e de quase $11 \%$ das notificações (Tabelas 3,4 e 5).

Neste estudo, apesar de o grau de escolaridade do grupo não poder ser definido com precisão, dado o grande percentual de gestantes HIV+ com anos de escolaridade ignorados ( $41 \%)$, a presença de, aproximadamente, $40 \%$ de gestantes com $1^{\circ} \mathrm{grau}$ incompleto (tabela 6), permite admitir que a população de estudo apresenta baixa escolaridade. Dados do Ministério da Saúde (MS 2000) apontavam que, no Brasil, mais da metade das mulheres infectadas, com idade acima de 19 anos, tinham até 8 anos de escolaridade.

A baixa escolaridade (até 3 anos de estudo) fica bem evidente entre gestantes de 13 e 14 anos (100\%) e no grupo de 35 a 43 anos (43\%). (tabela 8).

Este dado de escolaridade representa uma característica muito importante dessas mulheres, por ser um fator que agrava as condições de submissão da mulher ao seu companheiro, e, ao mesmo tempo, lhe dificulta o acesso às informações e aos serviços básicos de saúde; e que, de acordo com Barbosa e Villela (1996), este é um dos dados retirados de fontes epidemiológicas que mais evidenciam diretamente a vulnerabilidade da mulher ao HIV ' conforme discutido por Santos (1994) e BETINI (1997) 
A faixa etária que compreende o maior número de casos está entre 20-24 anos, 85 casos (45,2\%), seguida de 25-29 anos, 38 casos (20,2\%) (tabela7).

Ainda que aparentemente baixo, o número de gestantes contaminadas na idade de 13 e 14 anos (representando $2,1 \%$ do total) denota um duplo problema para a saúde da mulher: precocidade com gravidez de risco e possível desenvolvimento de Aids.

Quanto à distribuição dos casos, segundo categoria de exposição, a epidemia pelo HIV/Aids vem crescendo consideravelmente entre heterossexuais, passando a constituir a principal modalidade de exposição ao HIV, desde 1993, para o conjunto de casos notificados, superando as relações "homo" e "bissexuais"(MS 2000; PARKER e BARBOSA 1996). A transmissão do HIV no Espírito Santo dá-se, principalmente, durante atos sexuais (heterossexuais): dos 108 casos notificados, quase $60 \%$ são confirmados, conforme tabela 9 . Embora questionando informações publicadas no Boletim Epidemiológico sobre Aids, pelo Ministério da Saúde, em 1999 (MS 1999a), segundo o qual, na categoria de exposição heterossexual, prevalece na transmissão vertical o uso de drogas injetáveis pela mãe ou por seu parceiro, aparecendo Vitória, no período 1993-1999, com $40 \%$ dos casos, neste estudo não foi possivel constatar tal fato, talvez, pelo alto percentual de casos ignorados (35\%), conforme tabela 9.

Sabe-se que, na transmissão heterossexual do vírus HIV, a situação de risco do parceiro representa um dado importante para uma maior ou menor chance de contaminação. Calcula-se, também, que $47 \%$ das parceiras de homens com Aids são infectadas com HIV. De acordo com SCHECHTER (1994), os maiores fatores de risco para as companheiras são: a prática da relação anal; a situação de risco a que pertence o doente, os usuários de drogas transmitem mais o vírus do que os bissexuais; a fase clínica da doença - quanto mais avançada, mais contagiosa; a freqüência da relação sexual; e a presença de outras doenças, sexuaimente transmissiveis.

Devido à freqüente discussão e divulgação sobre a promiscuidade, como um fator-chave na transmissão do HIV, veiculada em campanhas publicitárias do governo, a maioria das pessoas acredita que a redução do número de parceiros sexuais diminui o risco de infecção pelo HIV (DIAS 1999). 
Conforme SCHECHTER (1994), a manifestação da Aids é tardia, ocorrendo, na maioria das vezes, entre o quinto e décimo ano de infecção. A manifestação dos sintomas ocorre, porque já decorreu tempo suficiente de infecção para permitir agravos no organismo de pessoas que vivem com HIV.

Segundo MONTAGNIER (1995), o surgimento de doenças oportunistas demonstra que o sistema imunológico das pessoas que vivem com HIV já sofreu sérios comprometimentos e pode significar uma mudança de padrão da doença. 0 indivíduo passa da condição de soropositivo para o estágio manifesto da Aids ou do complexo de doenças relacionadas à Aids.

BARBOSA e VILLELA (1996) assinalam que há maior demora em diagnosticar a Aids entre mulheres, resultando em intervenção tardia e diminuição do seu tempo de sobrevida. Por outro lado, homens procuram realizar o teste antiHIV, bastando desconfiarem de uma exposição ao vírus e, assim, iniciam mais cedo o tratamento, melhorando a sobrevida.

Segundo VILLELA (1997), quanto mais cedo as pessoas infectadas iniciarem o tratamento anti-HIV, maiores serão as chances de terem uma quantidade e uma qualidade de vida melhor.

Sabe-se que são vários os fatores que, articulados de forma diferente, configuram a vulnerabilidade ao HIV. Dentre eles, podem-se citar o gênero, a classe social e as opções sexuais, como os mais freqüentemente envolvidos nesse processo. Fazendo parte desse contexto, usar ou não o preservativo, pode ser a única medida que separa ou aproxima as pessoas da vulnerabilidade ao HIV (LANE e CODO 1984).

Sendo as mulheres mais suscetiveis às doenças sexualmente transmissiveis do que os homens, a incidência do risco de transmissão do vírus HIV, naquelas, é preocupante e requer atenção especial, principalmente na gestação, por implicar, também, o bem estar do feto em formação e a estrutura da familia, especialmente outros filhos. Atualmente, as mulheres constituem um grupo que vem sendo atingido, de forma crescente, pela contaminação pelo vírus HIV, contribuindo, de forma assustadora, para o crescimento do número de casos de Aids em recémnascidos. 
Por isso, é altamente preocupante que, no registro das gestantes HIV+ do Espírito Santo fosse ignorado, em 30\% delas, a realização do pré-natal (tabela10), pois quase $73 \%$ dos diagnósticos laboratoriais da contaminação pelo vírus HIV e, aproximadamente, $72 \%$ dos casos confirmados de Aids ocorreram durante o prénatal (tabela11 e 17).

O primeiro trimestre de gestação é o período adequado para o início do prénatal, porém a mulher deve estar sendo assistida, mesmo antes de engravidar. No Brasil, o Ministério da Saúde/Portaria no 569/2000 recomenda que a primeira consulta seja realizada até o quarto mês de gestação, que haja, no mínimo, 6 consultas de acompanhamento pré-natal, uma delas deve ocorrer, preferencialmente, no primeiro trimestre de gestação, duas, no segundo e três, no terceiro (MS 1999a, 1999b, 1999d, 2000).

A feminilização da Aids é um reflexo do comportamento sócio-sexual da população, associado a aspectos de vulnerabilidade biológica e de gênero. A mulher considera-se menos exposta ao risco, talvez pela sua entrada mais tardia na dinâmica da epidemia, não se enquadrando nos, inicialmente, chamados "grupos de risco"; sua contaminação, entretanto, traz, como conseqüência, o aumento de casos entre crianças. WALDVOGEL (1997) declara que a transmissão vertical (de mãe para filho) é a principal via de infecção pelo HIV na população infantil, sendo responsável, no Brasil, por mais de $90 \%$ dos casos em menores de 13 anos.

No contexto de vulnerabilidade ao HIV, muitas vezes, mulheres acreditam-se fora de risco, por viverem uma relação estável. Também, cabe ressaltar, a atitude de prevenir os riscos de contaminação pelo HIV depende muito do poder de barganha que tem a mulher. Ao insistir no uso da camisinha, algumas mulheres receiam estar colocando em risco sua relação, ou, mesmo, perder seu parceiro. Perdendo o parceiro, algumas podem estar abrindo mão de uma relação que thes dá status e apoio emocional, além do suporte financeiro necessário à sobrevivência.

Para as mulheres soropositivas, a convivência com o HIV e com a Aids é mais dramática, do que para os homens. Faltam políticas que garantam a efetivação dos seus direitos, o serviço de saúde não está preparado para cuidar da saúde reprodutiva e sexual de mulheres soropositivas e para lidar com temas, como direito de ter filhos, acesso à reprodução assistida e direito ao aborto. Das 188 
gestantes HIV+, registradas na SESA, no período de 1999-2002, $70(37,2 \%)$ delas tiveram confirmação de Aids, percentual que poderia ser maior, considerando que $33 \%$ das mesmas ignorava o resultado do teste, mostrado na tabela 15 . Será que foram realizados os testes? Será que não foi preenchido o resultado? São indagações que mereceriam um aprofundamento nas investigações.

Situação mais grave é o fato de que, das 70 gestantes com confirmação de Aids, apenas $44(62,9 \%)$ fizeram uso do anti-retroviral e, das 62 gestantes HIV+, em que se ignorava o diagnóstico da Aids, em 47 delas (75,8\%) também se ignorava o uso de anti-retroviral (Tabela 16).

O número de 188 casos de gestantes HIV positivas, que foram encontrados durante a coleta de dados na Secretaria de Saúde do Estado do Espírito Santo, representa o universo assinalado durante a pesquisa. Contudo, devido aos elevados índices de "ignorados" e em branco, em grande parte das fichas de investigação, é de se supor que a incidência da transmissão vertical, no Espírito Santo, seja maior do que a encontrada no presente estudo. Os dados coletados sugerem que o baixo número de gestantes que receberam tratamento durante o pré-natal, parto e pósparto, podem estar expressando fatores que dificultam a identificação da gestante infectada pelo vírus HIV: o tipo de assistência prestada à mulher pela equipe de saúde, o acesso aos testes anti-HIV e o medo da mulher quanto à exposição, ao preconceito e à repercussão que possa gerar na comunidade familiar e social, a partir da positividade do teste.

A maior parte das transmissões verticais do bebê ocorre, ainda, na vida intra-uterina, e, portanto, em período em que as condições de intervenção do médico são reduzidas. É necessário, também, levar em conta que o risco de transmissão varia, conforme o estado da infecção materna, sendo maior nas fases mais avançadas da doença.

Profissionais de saúde e, em especial, o médico, devem informar à mulher infectada a respeito de todos os dados atuais, relativos ao assunto, mas não podem impedi-la de ter filhos. Esta situação se assemelha àquela com que se defrontam médicos responsáveis por aconselhamento genético, em relação à evidência de um risco aumentado de nascimento de crianças infectadas. 
Da mesma maneira, o médico, ou a instituição de assistência médica, não tem o direito de negar assistência à mulher infectada, durante a gestação e o parto. Já, uma clínica privada pode recusar o atendimento a qualquer paciente, mas, obedecendo às situações em que está obrigada a atender, ou seja, na ausência de outro médico, na localidade, capacitado para esse tipo de atendimento, em casos de urgência, ou, quando sua negativa pode resultar em danos irreversíveis ao paciente, sob risco de omissão de socorro. No entanto, se o médico mantiver relação de trabalho com entidade pública ou privada, que inclua atendimento a pacientes gestantes, terá ele de manter seu compromisso de atendimento, independentemente de sua maneira pessoal de encarar a situação considerada. As mesmas considerações, evidentemente, valem para qualquer instituição de assistência médica.

O diagnóstico precoce, durante a gravidez, permitirá identificar as mulheres que poderão se beneficiar dos processos terapêuticos disponiveis atualmente, melhorando, assim, a qualidade da sua gestação, possibilitando o oferecimento de aconselhamento quanto aos cuidados pós-natais, no sentido de reduzir o risco de transmissão do HIV para o recém-nascido não contaminado. Permitirá, também, maior atenção para a possibilidade de ter ocorrido transmissão vertical, com vigilância diagnóstica e eventual instituição precoce de terapêutica para a criança infectada.

As características especiais dessa infecção, suas repercussões sociais e os riscos de discriminação a ela ainda inerente, fazem com que sejam tomados cuidados ainda mais específicos do que aqueles que cercam outras infecções, que estão longe de trazer aos indivíduos, por elas acometidos, os transtornos de múltiplas naturezas que atingem os portadores da Aids. Daí ser obrigatório que o médico discuta a realização do exame com sua paciente, informe-a adequadamente quanto à sua utilidade, e lhe dê garantias de confidencialidade quanto ao resultado, obtendo, então, a autorização para o teste sorológico. A negativa, por sua vez, não deve trazer prejuízos à paciente, e ela, também, não deve ser ameaçada nesse sentido. Seu consentimento deve ser por convencimento, e não por temor de perda de direito à assistência médica ou outras, oferecidas pela instituição. 
Da mesma maneira que para a mãe, é evidente que o diagnóstico precoce poderá trazer benefícios terapêuticos para a criança, já infectada. Assim, quando houver indicação clínica, ou suspeita epidemiológica, que justifique a realização de exames diagnósticos, o médico deverá informar aos responsáveis pela criança e obter autorização específica para efetuar os testes utilizados para essa finalidade. Mas, eles podem negar a realização desses testes, devido à falta de conhecimento, medo ou avaliação de que o exame positivo do recém-nascido poderá permitir conclusão indesejada de existência de infecção na mãe e, talvez, também no pai. Em caso de recusa, o médico deve explicar à família as possiveis conseqüências, registrando a recusa no prontuário da criança (ARRUDA e col. 1987). Neste estudo,não aparecem nas fichas de registro de notificação, nenhuma alusão a tal recusa, ou qualquer outro fato que impedisse o registro; simplesmente, não foi preenchido o campo (o que equivale, para todos os efeitos, a campo ignorado), o que, certamente, dificulta qualquer tipo de avaliação, a não ser a negativa dos serviços de atendimento a essa população.

A gestante soropositiva para o HIV, mesmo sem apresentar os sintomas da Aids, e seu recém-nascido, têm que ser notificados, mediante preenchimento de ficha específica, que começou a ser distribuída aos serviços de pré-natal, maternidades e aos pediatras. $O$ primeiro grande passo de apoio a essa vigilância foi a revisão da Portaria Ministerial no 1.461, publicada em setembro de 2000, com a inclusão da infecção, pelo HIV, em gestantes e crianças expostas à transmissão vertical, como Agravo de Notificação Compulsória (MS 2000).

Apesar dos avanços científicos e dos esforços do Ministério de Saúde em disponibilizar AZT oral e outros ARV (antiretrovirais), desde 1994, para todas as gestantes; AZT injetável, desde 1996, para todas as parturientes; e AZT solução oral para todos os recém-nascidos expostos ao HIV, até 31 de março de 2001, foram notificados ao Ministério da Saúde 7.335 casos de Aids em menores de 13 anos de idade, sendo 5.924 (60,8\%) devido à transmissão materno-infantil do HIV. Situação essa que só será revertida quando for garantida a qualidade na assistência pré-natal, ao parto, puerpério e ao recém-nascido e nos serviços voltados à assistência de portadores do HIV e seus filhos (MS 2000; SMELTZER e BARE 2002; TAMBEIRO 2001). 
Observa-se, neste estudo, pela Tabela 13, o alto percentual de gestantes (quase $38 \%$ ) que não fizeram uso de antiretrovirais para profilaxia da transmissão vertical durante a gravidez, o que, somado a $29 \%$ de casos ignorados, denota o nível de desinformação das mesmas, assim como e, principalmente, o descaso dos serviços municipais e estaduais de atendimento à saúde, do Espírito Santo, com essa condição.

A orientação técnica atual é que o uso da profilaxia com AZT oral deve ser iniciado a partir da $14^{a}$ semana de gestação e continuar durante o trabalho de parto, e, do parto até o champeamento do cordão umbilical. Quando a oportunidade de profilaxia, no início da gestação, for perdida, esta pode ser iniciada em qualquer idade gestacional, inclusive, no momento do parto (MS 1999a, 1999b, 1999c, 2000).

Neste estudo, o início da profilaxia com AZT ocorreu, em maior número, em mulheres na $16^{a}$ semana de gestação, correspondendo a 20 casos $(10,6 \%)$, sendo o número de ignorados - 94 casos (50\%) - bastante alto (Tabela 12); o tempo de uso de AZT oral pelas gestantes, entre a $13^{a}$ e $40^{a}$ semanas, foi de $28,1 \%$ e 0 número de ignorados, 96 casos (51,1\%), excessivamente elevado (Tabela 14).

É reconhecido que o AZT reduz a carga viral, preserva as células de defesa do organismo e, também, reduz a possibilidade de transmissão vertical. Toda gestante HIV+ deve usar o AZT, antes e durante o parto, para proteger a criança recém-nascida de uma possivel contaminação (MS 1999a, 1999b, 1999c, 2000).

Segundo o Ministério da Saúde, esse procedimento é importante, à medida que a maioria dos casos de transmissão vertical materno-infantil do HIV, $65 \%$, ocorre durante o trabalho de parto, e, no parto propriamente dito, e os $35 \%$ restantes ocorrem intra-útero, principalmente, nas últimas semanas de gestação, e o aleitamento materno representa risco adicional de transmissão. No caso de gestantes HIV positivas, o presente estudo mostrou que somente $63,0 \%$ delas (Tabela 20) tinham usado AZT durante o parto.

É reconhecido, ainda, que a transmissão vertical ocorre, principalmente, no período próximo ao parto, ou durante o mesmo, o que determina a necessidade de realização de sorologia para HIV, nas gestantes, durante o pré-natal, independente 
do período gestacional e, nas maternidades, no momento do parto (MS 2001; MONTAGNIER 1996).

Em face desse conhecimento, o parto requer uma decisão importante para reduzir a transmissão vertical, que se faz através da a opção pela cesariana eletiva, evitando-se a urgência obstétrica. Essa decisão só pode ser tomada, caso tenha sido feito um pré-natal de qualidade e com planejamento e previsão da cesárea eletiva. Gestantes que têm seu diagnóstico de HIV+, no momento do parto, dificilmente têm condições de realizar a cesárea eletiva, visto que, se houver a urgência obstétrica, ela já se encontra instalada. Portanto, mais uma vez, faz-se presente a necessidade de serviços de saúde com qualidade, que prestem atendimento adequado à mulher na gestação e no parto (MS 2001; MONTAGNIER 1996).

Pela literatura consultada, e pelas próprias recomendações do Ministério da Saúde, causa muita estranheza o resultado encontrado no Espírito Santo, ao se constatar que não houve, em relação ao parto, nenhuma predominância entre cesáreo e normal, como era de se esperar, sendo a proporção para o primeiro de $43,6 \%$ e para o segundo de $42 \%$ (Tabela 18 ). Ainda mais grave é que foram constatados que apenas metade das mulheres $(51,9 \%)$ que realizaram parto normal, fez uso do anti-retroviral, no momento do parto; enquanto que, entre aquelas que realizaram parto cesariano, $84,1 \%$ delas fizeram uso do AZT naquele momento (Tabela 19).

São vários fatores que, associados, permitem o aumento do risco de transmissão do HIV da mãe para o filho, e, podemos citar, dentre eles: fatores virais, tais como carga viral, genótipo e fenótipo viral, diversidade circulante de resistência viral; fatores maternos, incluindo estado clínico e imunológico; presença de DST e outras co-infecções e o estado nutricional da mulher; fatores comportamentais, tais como o uso de drogas e práticas sexuais desprotegidas; fatores obstétricos, tais como a duração de ruptura das membranas amnióticas, a via de parto e a presença de hemorragia intraparto; e fatores inerentes ao recémnascido, tais como prematuridade, baixo peso ao nascer e a transmissão pelo aleitamento materno (MS 1999a, 1999b, 1999c, 2000). 
Dentre estes, reconhece-se, hoje, a carga viral elevada e a ruptura prolongada das membranas amnióticas, como um dos principais fatores associados à transmissão vertical do HIV. É por isso que a presença de carga viral nas secreções cérvico-vaginais e no leite materno tem se mostrado, respectivamente, importante determinante de risco de transmissão intraparto e pela amamentação (MS 1999a, 1999b, 1999c, 2000).

As evidências, descritas acima, apontam para a importância da promoção de intervenções, que propiciem a realização rápida do parto, com adequada assistência ao binômio mãe HIV+ e seu filho, o uso de AZT na gestação, durante o trabalho de parto e pelo recém-nascido (quimioprofilaxia da Transmissão Materno-Infantil - TMI do HIV) e, quando houver indicação, o uso de terapia anti-retroviral combinada pela gestante, e da operação cesariana eletiva, conforme recomendação do documento de consenso de gestantes "Recomendações para Profilaxia da Transmissão Materno-Infantil - TMI do HIV e Terapia Anti-Retroviral em Gestantes", revisada, periodicamente, pela Coordenação Nacional de DST/Aids (MS 1999c, 2001; MONTAGNIER 1996).

No Brasil, não obstante a disponibilidade de testes e de medicação profilática, que possibilitam taxas reduzidas de transmissão vertical, crianças continuam a se infectar. Muitas mulheres chegam à maternidade sem terem freqüentado o pré-natal, sendo ainda menor a freqüência entre gestantes mais vulneráveis à infecção pelo HIV, em decorrência de fatores, como baixa adesão ao pré-natal e/ou adesão tardia. Em outras palavras, para grande parte das mulheres HIV+, a única oportunidade de terem acesso ao aconselhamento, ao teste para a pesquisa do HIV e ao tratamento quimioprofilático da transmissão vertical, tem sido a hora do parto. Reconhece-se que este não é o momento ideal para o fornecimento e realização do teste anti-HIV. Entretanto, negar à mulher a oportunidade de ser testada e de disponibilizar o tratamento quimioprofilático adequado, para ela e para o recém-nascido, estando tal terapia disponível, e, com isto, reduzindo significativamente a chance de a criança se infectar pelo HIV, parece mais danoso do que qualquer discussão sobre a propriedade da testagem no momento do parto (MS 1999c, 2001; MONTAGNIER 1996). 
No estudo realizado, o estado de nascimento do recém-nascido, em 166 casos $(88,3 \%)$ foi de recém-nascidos vivos (Tabela 22 ), e o tempo transcorrido até o uso do AZT pelo recém-nascido, nas primeiras 24 horas, ocorreu em 141 casos (75\%) (Tabela 23). Após 24 horas, 64 (34\%) dos recém-nascidos apresentaram sorologia negativa, observando-se o expressivo número de ignorados, com cerca de 114 casos - 60\% (Tabela 24).

Outra orientação é que o recém-nascido deve receber o AZT oral nas primeiras 8 horas após o nascimento, mantendo essa medicação durante as primeiras 6 semanas de vida (42 dias), dado que este período é fundamental para evitar que o recém-nascido contraia o vírus HIV. Desta forma, todo recém-nascido, de mãe portadora do vírus HIV/Aids, deve receber AZT oral, mesmo que sua mãe não tenha recebido AZT na gestação (MS 1999a, 2001; MONTAGNIER 1996).

Da mesma forma, não é indicado o aleitamento materno ao recém-nascido, devendo-se recorrer ao aleitamento artificial, com fórmulas apropriadas ou leite humano, pasteurizado em banco de leite, não se devendo permitir aleitamento materno cruzado (leite de outra mulher), para que não ocorra a transmissão vertical, pois este é um dos fatores de risco para a criança recém-nascida (MS 2001). No presente estudo, em 140 casos $(74,5 \%)$ não ocorreu o aleitamento materno (Tabela 21).

No caso da população estudada, pode-se afirmar que esta recomendação foi seguida, pois apenas $9 \%$ das parturientes utilizaram o aleitamento materno para alimentar os filhos, ainda que em 16,5\% apareçam, como ignorada, a fonte de alimentação (Tabela 21).

Considera-se que o número de casos de Aids pediátrico vem aumentando progressivamente em todo Estado do Espírito Santo. Ressalta-se, ainda, que a progressão da Aids ocorre rapidamente, e a maioria das crianças vive menos de um ano, depois de feito o diagnóstico clínico.

O diagnóstico precoce, durante a gravidez, permite identificar as mulheres que poderão se beneficiar dos processos terapêuticos disponiveis atualmente, melhorando assim, a qualidade da sua gestação, possibilitando o oferecimento de aconselhamento quanto aos cuidados pós-natais, no sentido de reduzir o risco de transmissão do HIV para o recém-nascido não contaminado. Permitirá, também, 
uma maior atenção para a possibilidade de ter ocorrido transmissão vertical, com vigilância diagnóstica e eventual instituição precoce de terapêutica para a criança infectada.

Em função disso, a assistência pré-natal é um fator predominante na prevenção e no tratamento de patologias, que põem em risco o bem-estar materno e fetal, proporcionando uma redução nas taxas de morbimortalidade materna, fetal e neonatal.

O aconselhamento pré-natal constitui uma etapa decisiva para 0 enfrentamento do processo de diagnóstico, uma vez que este é o momento adequado para se estabelecerem os passos futuros, com o intuito de se alcançar um desfecho positivo, ou, pelo menos, não traumático, para a história que se inicia com a decisão de se fazer um teste anti-HIV.

Diante do exposto, caminha-se para uma reflexão no sentido de que, para o bom funcionamento de um programa, é necessária uma equipe de saúde qualificada e empenhada na formação e divulgação de informações que proporcionem, às gestantes, segurança e conforto para uma gestação saudável, tanto para a mãe, quanto para o bebê.

De igual importância é o cumprimento, por parte dos serviços de saúde, das recomendações emanadas da coordenação nacional da DST/Aids, do Ministério da Saúde, para gestantes, atendidas no âmbito do Sistema Único de Saúde - SUS, e pelo correto preenchimento da ficha de notificação gestantes HIV + , base para se ter uma exata idéia do andamento do programa e, em especial, dos cuidados ofertados a este binômio mãe-filho.

A Aids apresenta-se como um dos grandes desafios para a Saúde Pública. Em princípio, foi suposta como uma doença de região geográfica limitada, ou mesmo, um grupo especifico de pessoas; atualmente, o quadro se inverte, significando um "problema" de todos e impondo-se como uma "pandemia".

No início da epidemia, na década de 80 , imperava a falta de conhecimento, que gerou muitos estigmas que se perpetuaram até hoje, dificultando uma tomada de consciência coletiva frente à infecção pelo HIV. Atualmente, muita coisa foi descoberta, todavia, infelizmente, apesar das novas drogas encontradas, ainda não podemos comemorar a descoberta da cura, mas já se vislumbra a possibilidade de 
uma melhora na qualidade de vida do portador e do doente. Mas, o avanço da infecção ainda assusta e a prevenção permanece como única alternativa. A disseminação da informação para a população apresenta-se como componente fundamental da prevenção; neste sentido, os Programas Nacionais de DST/Aids atuam visando, ao menos, reduzir a vulnerabilidade dos individuos à infecção pelo HIV. Neste aspecto, a importância da informação, enquanto componente de prevenção à infecção pelo HIV, é consenso (BETINI 1997).

Assegurar à gestante um volume maior de informação sobre os riscos de contágio e transmissão do HIV é o mínimo que se pode fazer, trabalho este que pode ser realizado sem maiores custos pelos profissionais de saúde, visto que só depende do engajamento dos mesmos.

Reconhece-se que a comprovada eficiência das medidas de prevenção à transmissão do HIV da mãe para o filho tem sido insuficiente para impedir que mais de $90 \%$ dos casos de Aids, entre menores de 13 anos, tenha como causa a transmissão vertical (MS 2000). Isto acontece, entre outros motivos, porque a cobertura de realização de testes para o HIV no pré-natal, no Estado do Espírito Santo, é muito inferior ao desejado.

Vale ressaltar que o número de casos ignorados, no decorrer do estudo, corresponde ao não preenchimento ou ao preenchimento incompleto da Ficha de Notificação/Investigação Gestantes HIV+ e Crianças Expostas, por profissionais de saúde, o que sugere que está ocorrendo falha por parte desses profissionais, ou ainda, que as gestantes HIV+, por não quererem ser expostas, omitem dados relevantes constantes na Ficha. O número de ignorados, no estudo, chega a percentuais expressivos em torno de até $60 \%$, o que aponta para a necessidade do fortalecimento das ações de prevenção em saúde pública e maior organização e integração no Sistema de Informações em saúde do ES. 


\section{CONSIDERAÇÕES FINAIS}

Os dados deste estudo permitiram alcançar algumas conclusões, considerados os objetivos delineados para este trabalho:

\section{a. Verificar as tendências na taxa e transmissão vertical do HIV no Estado do Espírito Santo, no período de 1999-2002.}

A transmissão vertical do HIV, no Estado do Espírito Santo, concentra-se nos municípios da Região da Grande Vitória, sendo o município de Vitória, capital do Estado, o de maior expressão: $70 \%$ dos casos de residência e $90 \%$ de notificação. Isto se dá, devido à maior convergência populacional nas zonas urbanas,cerca de $78 \%$ da população.

Nos últimos anos, Vitória, a capital do Estado, sofreu um aumento desordenado da população, devido ao recrutamento de mão-de-obra para implantação de grandes projetos. Concluídas as obras, essa grande massa populacional permaneceu na Região da Grande Vitória e ficou desempregada. Parte da população feminina envolvida, por motivo de sobrevivência, ficou sujeita à prostituição e à promiscuidade, gerando, provavelmente, a contaminação de um grande número de mulheres em idade reprodutiva. Além do mais, considera-se, também, nesse contexto, que Vitória é uma cidade portuária, sujeita a essas alterações populacionais. Soma-se a isto, também, a falta de informação, gerada pela baixa escolaridade, a dependência financeira e emocional dessas mulheres e a submissão aos seus parceiros, muitas vezes, contaminados.

$O$ dado da escolaridade alarga o entendimento do problema e das questões envolvidas na contaminação pelo vírus HIV: logo, uma mulher que tenha dificuldade em discutir com seu parceiro a necessidade de utilização de recursos preventivos específicos, torna-a mais suscetivel à contaminação.

Verifica-se que os dados discutidos, anteriormente, devem-se, portanto, a questões educacionais e comportamentais, que definem uma inclinação para a busca da sobrevivência, em detrimento dos cuidados necessários à prevenção do HIV. 
Quanto ao perfil da gestante infectada, o estudo concluiu que a baixa escolaridade representa uma característica muito importante dessas mulheres, por ser um fator que agrava as condições de submissão da mulher ao seu companheiro, e, ao mesmo tempo, dificulta-lhe o acesso às informações e aos serviços básicos de saúde, influenciando, de um modo complexo, as atitudes que levam às práticas de risco para o HIV.

A baixa faixa etária - que coincide com a sua idade reprodutiva -denota um duplo problema para a saúde da mulher: precocidade com gravidez de risco e possível desenvolvimento de Aids. O aumento da ocorrência de casos, em idade reprodutiva, tem, como conseqüência, o aumento da transmissão mãe-filho, isto é, a vertical.

No Espirito Santo, o estudo mostrou que a transmissão vertical dá-se, principalmente, durante atos heterossexuais, contrariando as informações publicadas no boletim epidemiológico sobre Aids, pelo Ministério da Saúde (1999), de que o uso de drogas injetáveis pela mãe ou seu parceiro é mais evidenciado para a transmissão vertical do que a categoria de exposição heterossexual.

Nesse aspecto, a partir da comparação entre dados da figura 9 e a tabela 9, verifica-se que, em relação à via de exposição à contaminação, o dado brasileiro é de $39 \%$ para usuários de drogas injetáveis, maior que o de mães com múltiplos parceiros, da ordem de $21 \%$ (fig 9). Enquanto que o dado espírito-santense revela que a via sexual foi a maior ( $57,5 \%$ dos casos) e, por drogas injetáveis, de apenas $5,9 \%$ (Tabela 9). 


\section{b. Identificar o número de gestantes e recém-nascidos que fizeram uso da terapêutica para prevenção da Aids pediátrica, no período do estudo.}

Pode-se concluir, pelo estudo, que:

$137(72,9 \%)$ das gestantes tiveram diagnóstico laboratorial do HIV, durante a realização do pré-natal; $105(55,9 \%)$ das gestantes fizeram pré-natal; $43(23,4 \%)$ de gestantes não receberam AZT durante o parto;

Em cerca de $96(51,1 \%)$ das gestantes ignora-se o tempo de uso do AZT oral e que $28,1 \%$ fizeram uso entre as $13^{\mathrm{a}}$ e $40^{\mathrm{a}}$ semana;

Das 70 gestantes com confirmação de Aids, somente 44 (62.9\%) fizeram uso do anti-retroviral;

Das 70 gestantes com confirmação de Aids, $71.4 \%$ fizeram o pré-natal; e.77,9\% dos recém-nascidos usaram AZT nas primeiras 24 horas

Portanto, as medidas de prevenção da transmissão vertical são eficazes quando aplicadas; porém, existem ações que precisam ser intensificadas, a fim de que os casos de Aids pediátricas sejam realmente evitados.

A detecção precoce da gestante HIV+, com aconselhamento pré e pós-teste é fundamental, porém o acompanhamento das gestantes até o nascimento da criança, pelas instituições de saúde, também necessita mudanças. Há necessidade de maior descentralização e integração dos serviços, para que haja um melhor acompanhamento a essas gestantes em seu município. A disseminação da informação sobre HIV+, gestação e parto deve ser intensificada em toda a comunidade. A logística de distribuição de medicamentos precisa ser reavaliada, porque, ainda hoje, existem várias maternidades e hospitais que não têm acesso, sequer à AZT oral. Há necessidade de implantação, em todos os centros, do cartão de identificação do paciente HIV+, a fim de que possa ser fornecida medicação à gestante, independentemente do local onde ela esteja, sem burocracias desnecessárias e, às vezes, constrangedoras.

Programas, como Saúde da Família, podem ser utilizados para a busca dos casos de abandono de tratamento e de casos recentes, em lugar da visita domiciliar dos Serviços de Referência em Aids, que pode causar constrangimento. A gestação é, em geral, um momento em que a mulher e a família estão receptivas para as 
orientações e ações de saúde, portanto, é necessário que os profissionais, que fazem parte dos programas voltados para a Saúde Pública, façam a sua parte.

Logo, para que haja redução da transmissão vertical é necessário informar, motivar e proporcionar recursos adequados para adoção de métodos preventivos e terapêutica apropriada, com o objetivo de se ter uma queda nos números da Aids e da transmissão materno-infantil e, assim, controlar a doença.

\section{c. Verificar quantas crianças foram negativadas, no periodo do estudo.}

Nesta pesquisa, constatou-se que das 166 crianças nascidas vivas, apenas 141 receberam a medicação anti-retroviral, nas primeiras 24 horas de vida; que 64 crianças foram negativadas, após 24 meses de acompanhamento pela equipe do Sistema de Informação em Saúde Pública do Estado, e que 114 foram ignoradas na notificação.

Questiona-se por que, em um universo de 166 crianças nascidas vivas, apenas 64 crianças foram negativadas. E, também, por que existe este número expressivo de casos ignorados.

Esses indices levam a refletir sobre as ações tidas como eficazes para a profilaxia da transmissão vertical, que não se confirmam. É possivel que o acompanhamento não esteja sendo feito adequadamente pela equipe de saúde, apesar dos esforços empreendidos pela Secretaria de Saúde do Estado e pelo Ministério de Saúde para a capacitação destes profissionais; e, que, devido a questões biopsicossociais, culturais e políticas, as mães soropositivas não estejam favorecendo a implementação dessas ações.

Tudo isto gera um agravo para o sistema de saúde, tendo em vista a falta de dados corretamente notificados no sistema, já que o número de ignorados é muito alto, cerca de $60 \%$, o que compromete o resultado final do estudo e aponta para a necessidade do fortalecimento das ações de prevenção em Saúde Pública e maior organização e integração no Sistema de Informação em Saúde do Espírito Santo.

Portanto, ao descrever o perfil epidemiológico da transmissão vertical do HIV no Estado do Espírito Santo, no período de 1999 a 2002, pode-se observar, pelas tabelas apresentadas, que houve um aumento de notificações de gestantes 
HIV positivas, sinalizando a eficácia na implementação de projetos de conscientização da população, para se abrir e procurar os serviços de saúde.

Percebe-se, contudo, que, apesar dos resultados do Protocolo 076 do Aids Clinical Trial Group (PACTG 076), que comprovaram que o uso da Zidovudina (o AZT) reduz a transmissão vertical do HIV, em $67,5 \%$, quando usado durante a gestação, trabalho de parto e pelos recém-nascidos, que foram alimentados exclusivamente com fórmula infantil e das estratégias utilizadas para a implementação/operacionalização de Políticas de Saúde Pública, houve um número significativo de pessoas que não foram envolvidas pelas estratégias de saúde, gerando um alto índice de transmissão vertical, já que apenas 64 crianças foram negativadas, num contexto de 166 crianças nascidas vivas.

Finalmente, os dados apresentados neste estudo também devem chamar a atenção para a necessidade de prevenção à Aids, que vai além da apresentação de informações básicas sobre a doença, como evitá-la e como tratá-la. É necessária, na promoção de programas preventivos, a abordagem de temas ligados aos aspectos sócio-cultural e psicológico, em parceria com temas ligados a práticas sexuais seguras.

A íntima relação entre prevenção da transmissão vertical do HIV e a assistência pré-natal e ao parto impõe que ações conjuntas sejam implementadas pelos programas de DST/Aids e Saúde da Mulher nos níveis federal, estadual e municipal. Apenas desta forma poderemos desenhar estratégias e executar ações efetivas para a redução da transmissão vertical do HIV, que alcancem o universo dessa população de risco e que dêem a sustentação necessária para atingir milhares de mulheres que, a cada ano, dão à luz, no Brasil. Este esforço, certamente, resultará não apenas na redução dos casos de aids em crianças, mas, também, em um ganho global para uma melhor assistência à saúde da mulher, no Brasil. 


\section{REFERÊNCIAS}

Arruda JM; Morris L; Rutenberg N. Pesquisa nacional sobre saúde maternoinfantil Infantil e Planejamento Familiar (PNSMIPF). Rio de Janeiro: BEMFAM; 1987.

Barbosa R, Vilela W. A Trajetória Feminina da Aids. Rio de Janeiro: RelumeDumará; 1996.

Betini G. Da Informação em Saúde ao Serviço como Informação. São Paulo; 1997. [Dissertação de Mestrado - Faculdade e Saúde Pública da USP].

Berer N. Mulheres e HIV/Aids: um livro sobre recursos internacionais. São Paulo: Brasiliense; 1996.

Buchalla CM. Aids: o surgimento e a evolução da doença. In Monteiro CA, organizador. Velhos e Novos Males da Saúde no Brasil. $2^{a}$ ed. São Paulo: Hucitec Nupens/USP; 2000. p. 81-89.

Cunha AC. Estrutura e apresentação de dissertação e teses. São Paulo: Universidade de São Paulo - Faculdade de Medicina, Serviço de Biblioteca e Documentação; 1996.

Czeresnia D. Do Contágio à Transmissão: ciência e cultura na gênese do conhecimento epidemiológico. Rio de Janeiro: Fiocruz; 1997.

Departamento Estadual de Estatística. Informações Municipais do Estado do Espírito Santo: 2001. Espírito Santo; 2001.

Dias EAC. Entre o Desejo e o Risco: os sentidos da gravidez na assistência à Aids. São Paulo; 1999. [Dissertação de Mestrado - Pontifícia Universidade Católica de São Paulo]. 
Fundação IBGE. Anuário estatístico do Brasil: 2001. Rio de Janeiro; 2002.

Instituto Brasileiro de Geografia e Estatística. Sistema de Contas Nacionais. Rio de Janeiro; 2001.

Lane S, Codo W, organizadores. Psicologia Social: o homem em movimento. São Paulo: Brasiliense; 1984.

Ministério da Saúde. Coordenação Nacional de DST/Aids. A Aids no Brasil: situação atual e tendências. Boletim Epidemiológico. Brasília (DF); 2002.

Ministério da Saúde. Coordenação Nacional de DST/Aids. Aids e pauperização: principais conceitos e evidências empíricas sobre a epidemia da Aids no Brasil: distintas abordagens. Brasília (DF); 1999a.

Ministério da Saúde. Coordenação Nacional de DST/Aids. A Infecção pelo HIV em Crianças: guia de tratamento clínico. Secretária de Políticas de Saúde. Brasília (DF); $1999 b$.

Ministério da Saúde. Coordenação Nacional de DST/Aids. Berquó E. Comportamento Sexual da População Brasileira e Percepçōes do HIV/Aids. Relatório final. [on-line]. Brasília; 2000. Disponível em <URL:http:/www.aids.gov.br> [2000 nov 16]

Ministério da Saúde. Coordenação Nacional de DST/Aids. Implantação da Vigilância do HIV em Gestantes e Crianças Expostas. Boletim Epidemiológico Aids. Brasilia (DF); 2000.

Ministério da Saúde. Coordenação Nacional de DST/Aids. Infecção pelo HIV em Adultos e Adolescentes: recomendaçōes para terapia anti-retroviral. Brasília (DF); 1999c. 
Ministério da Saúde. Coordenação Nacional de DST/Aids. Szwarcwald CL. Prevenção da Transmissão Vertical no Brasil. Boletim Epidemiológico de Aids. Brasilia (DF); 1999d.

Ministério da Saúde. Coordenação Nacional de DST/Aids. Recomendações para Profilaxia da Transmissão Materno-Infantil do HN e Terapia AntiRetroviral em Gestantes. Brasilia (DF); 2001.

Montagnier L. Aids: seus mecanismos e tratamentos. Rio de Janeiro: Zahar; 1996.

Montagnier L. Vírus e Homens. Rio de Janeiro: Zahar; 1995.

Parker R, Barbosa R, organizadores. Sexualidades Brasileiras. Rio de Janeiro: Relume-Dumará; 1996.

Parker R, organizador. A Aids no Brasil: 1982 - 1992. Rio de Janeiro: RelumeDumará; 1994.

Parker R, Galvão J, organizadores. Quebrando o Silêncio: mulheres e Aids no Brasil. Rio de Janeiro: Relume-Dumará; 1996.

Pimentel NLP. Aids Fim ou Recomeço. Revista Medicina com Saúde 2001; 3: 1315. Programa Nacional de Sida. Ministério de Salud. Sánchez J. La Prevención de la Tranmisión Vertical del HIV em Perú. Lima; 1998.

Rea MF. A Posição Atual da OMS UNAids e UNICEF sobre Mães HIV+ e Aleitamento Infantil. In: Anais do Seminário HIV e Amanentação; 1998; São Paulo, (BR). São Paulo: Secretária Estadual da Saúde/Instituto de Saúde; 1998. p. 18-26.

Ruiz JA. Metodologia Científica. $3^{a}$ ed. São Paulo: Atlas; 1991. 
Santo AH, Pinheiro CE, Jordani MS. Causas Básicas e Associadas de Morte por Aids, Estado de São Paulo, Brasil. Revista de Saúde Pública 2000; 34: 581-588.

Santos NJS. A Aids entre as Mulheres e a Aids. São Paulo; 1994. [Dissertação de Mestrado - Faculdade de Saúde Pública da USP].

Schechter M. Doenças Infecciosas e Condutas Terapêuticas. Rio de Janeiro: Guanabara; 1994.

Silva SFM. Análise da Situação Epidemiológica da Aids no Estado do Espírito Santo de maio a dezembro de 2001. Boletim Epidemiológico/DST/AIDS/ES 2001; 7: 19.

Silva SFM. O Direito da Criança Nascer sem o Vírus HIV. Boletim Epidemiológico/DST/AIDS/ES 1999; 3: 4.

Silva SFM. Situação Epidemiológica da Aids no Estado do Espirito Santo até novembro de 2002. Boletim Epidemiológico DST/AIDS/ES 2002; 8: 14 - 15.

Smeltzer SC, Bare BG. Tratado de Enfermagem Médico-Cirúrgica. $9^{\mathrm{a}}$ ed. Rio de Janeiro: Guanabara Koogan; 2002.

Soares M. A Aids. São Paulo: Publifolha; 2001.

Sontag S. Aids e suas Metáforas. São Paulo: Cia das Letras; 1989.

Szwarcwald CL, Carvalho MF. Estimativa do Número de Indivíduos de 15 a 49 anos Infectados pelo HIV, Brasil, 2000. Boletim Epidemiológico DST/AIDS/ES 2001; 1: 35-46. 
Tambeiro NMR. Prevenção da Transmissão Vertical da Infecção pelo HIV no Núcleo da Criança - NIC - Santos - SP - 1997 - 1999. São Paulo; 2001. [Dissertação de Mestrado- Faculdade de Saúde Pública da USP].

Ventura M. Direitos Reprodutivos no Brasil. São Paulo: MacArthur; 2001.

Villela W. Por uma Perspectiva Feminista frente à Epidemia de Aids entre as Mulheres. Jornal da Rede Saúde 1997; 14: 23-28.

Waldvogel B. Aids: principal causa de morte na idade reprodutiva. Jornal da Rede Saúde 1997; 14: 31-36.

World Health Organisation. Joint United Nations Programme on HIV/AIDS (UNAIDS). Aids Epidemic Update. Geneva; 2002.

World Health Organisation. Joint United Nations Programme on HIV/AIDS (UNAIDS). HIV in Pregnancy: a review. Geneva; 1998.

World Health Organisation. Joint United Nations Programme on HIV/AIDS (UNAIDS). Safety and Tolerability of Zidovudine. Geneva; 2000. 


\section{ANEXO 1}

\section{Fluxograma de Trabalho de Parto}

\section{Trabalho de Parto}

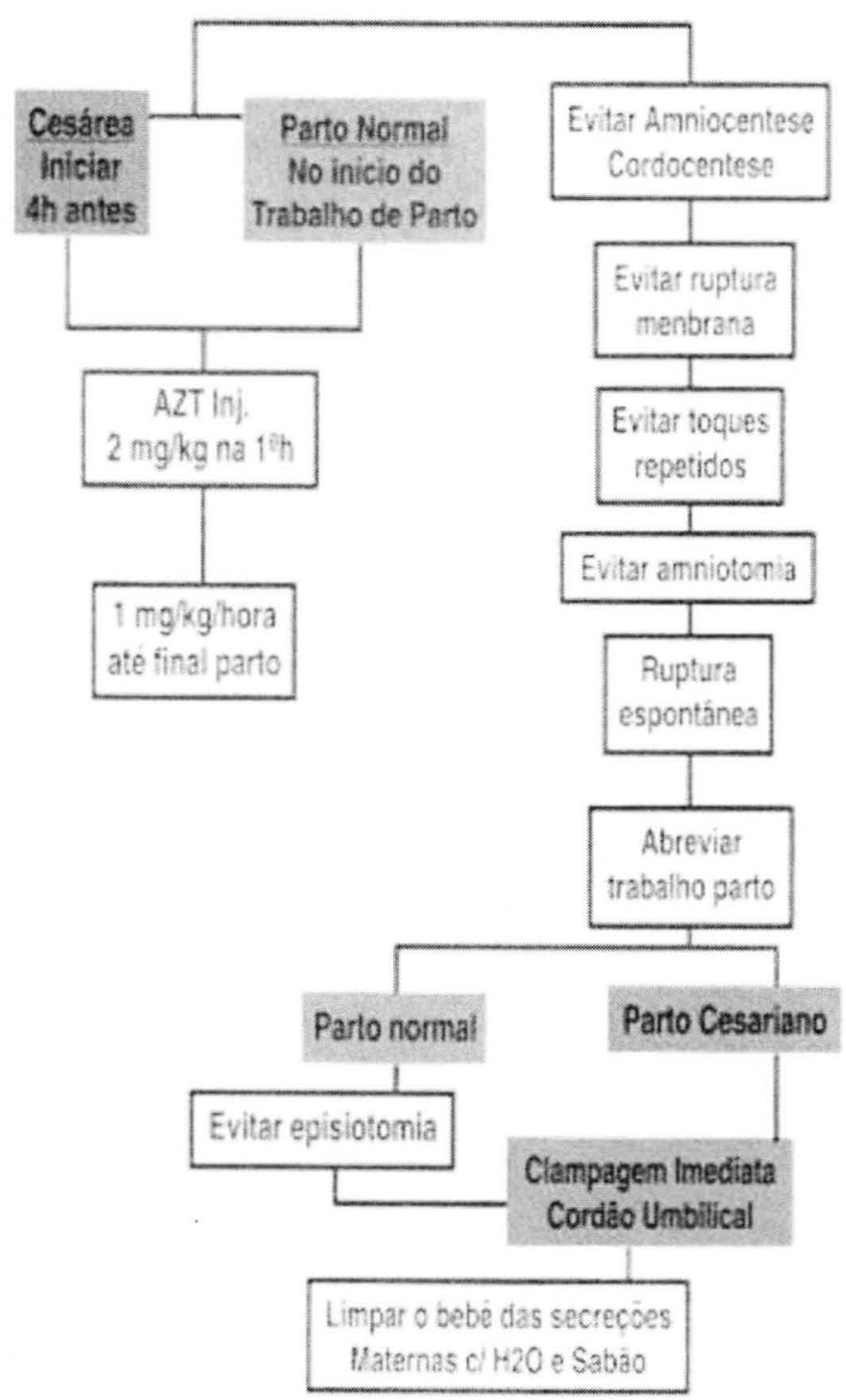




\section{ANEXO 2}

\section{CONDUTA PARA RECÉM-NASCIDOS DE MÄES HIVIAIDS}

Todo RN de gestante HIV/AIDS

deve receber AZI solucajo oral.

mesro que sua mile nio lerina tecesios AZT na cestatad

\section{Para o Recém-Nascido:}

Iniciar AZT solucio oral, preforencamente ato a $4^{2}$ hora apos

o nascimento, na ocsa 2 mokg a cara 6 hoces, durante

6 semanas (AZT solupio oral ic nigind?

\section{Excepcionaimente}

So PN naso tivet onducoss de AZl ora:

deve set ut izabo AZT netavel na mesma dose acma.

Ampola 200ing liomg m:

\section{AN Prematuro: Abaixo de 34 semanas}

Sugere-se dose de $1,5 \mathrm{mg} / \mathrm{g}$ de 1212 horas, VO ou EV. nas primeiras 2 semanas de vida, e $2 \pi \mathrm{g} \mathrm{kg}$ de 8.8 horas, por mais 4 semanas.

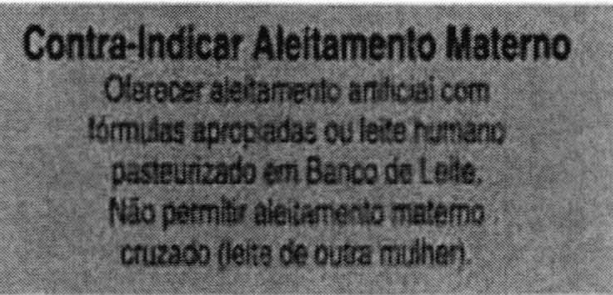




\section{ANEXO 3}

\section{Ficha de Investigação de Gestantes HIV+ e Crianças Expostas}

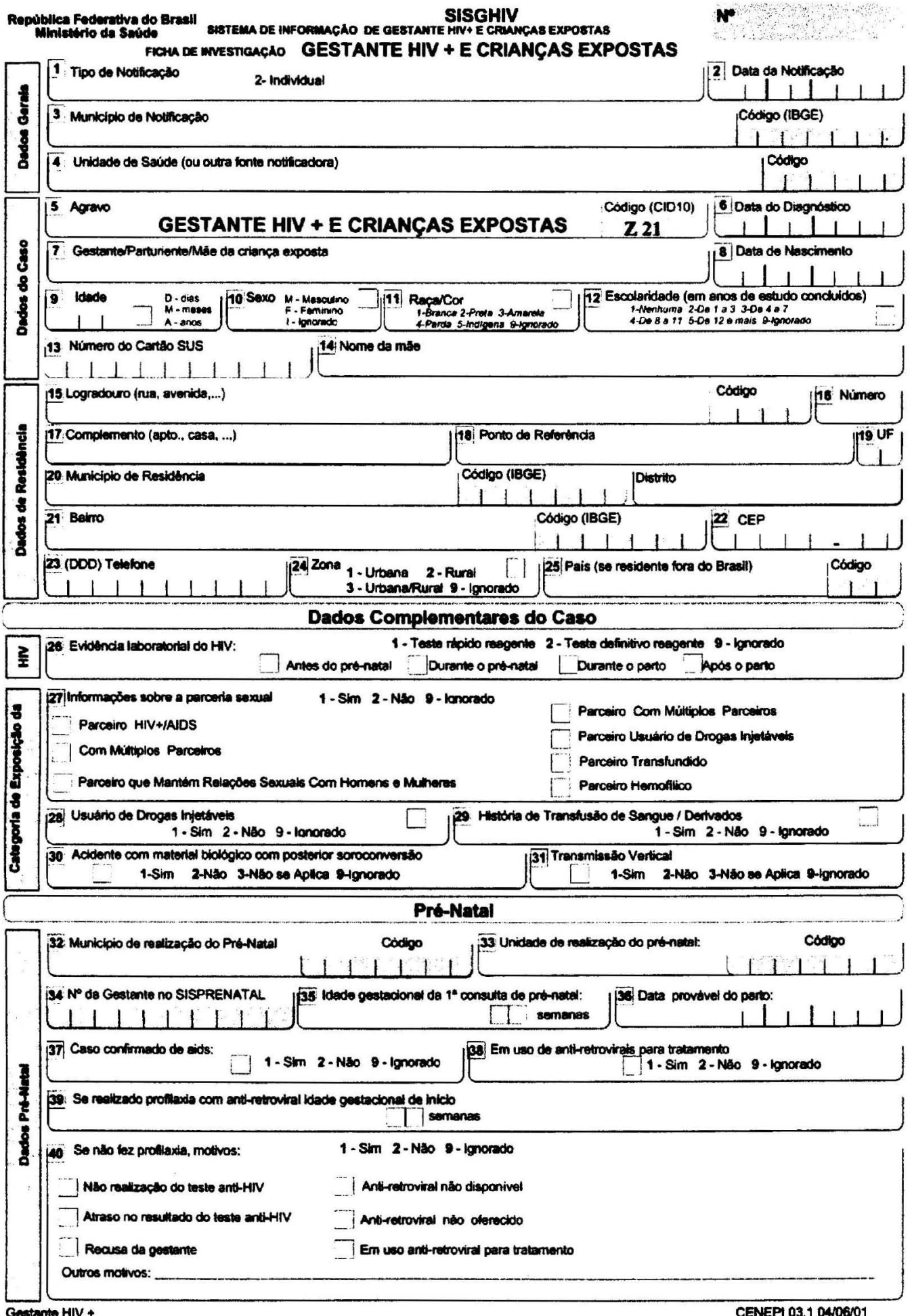

